\title{
The Potential of
}

Ligninolytic Fungi in

Bioremediation of

\section{Contaminated Soils}

\section{Erika Winquist}

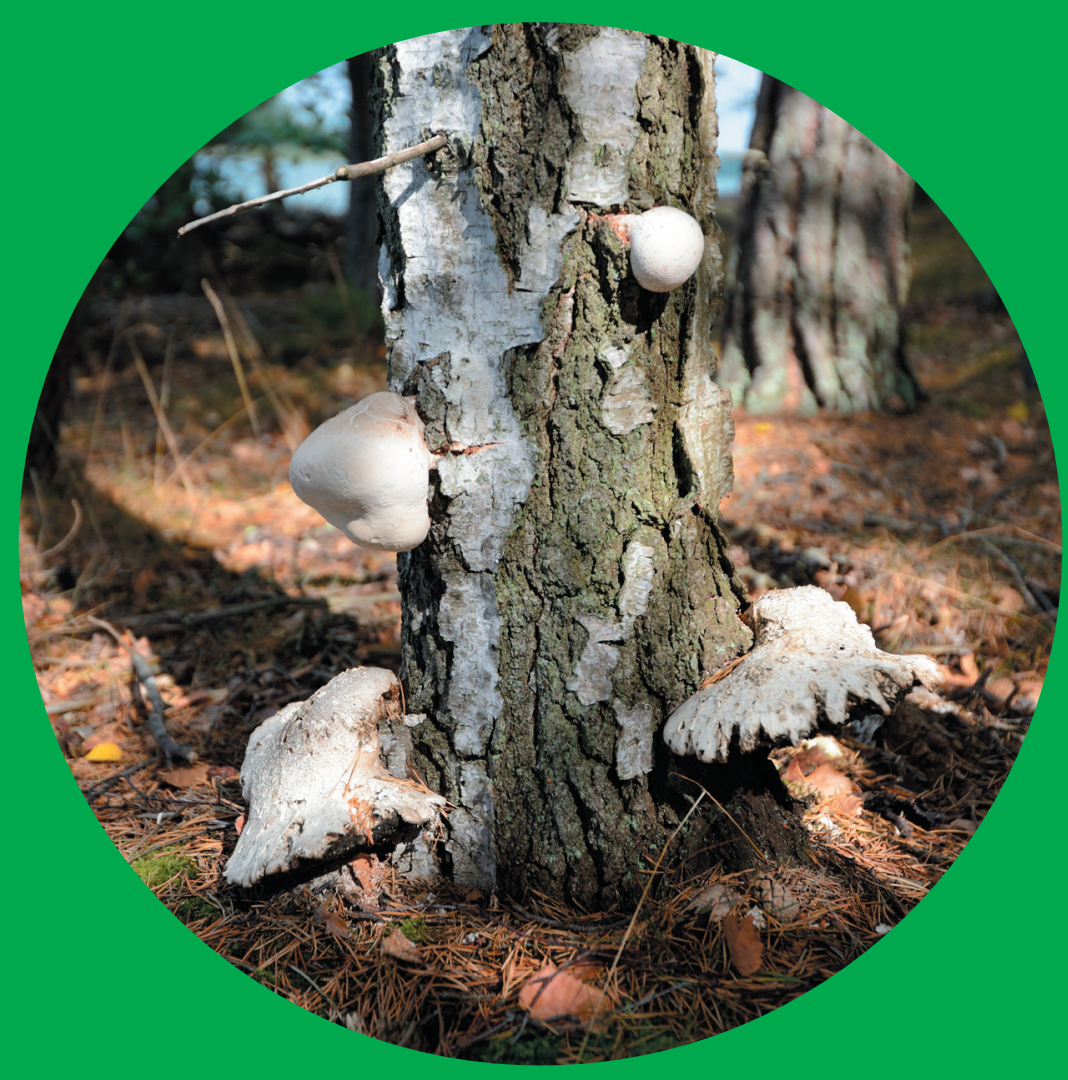




\section{The Potential of Ligninolytic Fungi in Bioremediation of Contaminated Soils}

\section{Erika Winquist}

A doctoral dissertation completed for the degree of Doctor of Science (Technology) to be defended, with the permission of the Aalto University School of Chemical Technology, at a public examination held at the lecture hall KE2 of the school on 16 May 2014 at 12. 
Professor Heikki Ojamo, Aalto University

\title{
Thesis advisors
}

PhD Marja Tuomela, University of Helsinki

Emeritus Professor Matti Leisola, Aalto University

Professor Emma Master, University of Toronto, Canada

\section{Preliminary examiners}

Professor Liliana Gianfreda, University of Naples Federico II, Italy PhD Jussi Heinonsalo, University of Helsinki

\section{Opponent}

Professor Spiros Agathos, Université catholique de Louvain, Belgium

\author{
(c) Erika Winquist
}

\section{ISBN 978-952-60-5656-2}

ISBN 978-952-60-5657-9 (pdf)

ISSN-L 1799-4934

ISSN 1799-4934 (printed)

ISSN 1799-4942 (pdf)

http://urn.fi/URN:ISBN:978-952-60-5657-9

Unigrafia Oy

Helsinki 2014

Finland 
Author

Erika Winquist

Name of the doctoral dissertation

The potential of ligninolytic fungi in bioremediation of contaminated soils

\begin{tabular}{|c|c|}
\hline \multicolumn{2}{|c|}{ nit Department of Biotechnology and Chemical Technology } \\
\hline Series Aalto University publication series DOCTORA & DISSERTATIONS 54/2014 \\
\hline \multicolumn{2}{|l|}{ Field of research Bioprocess Engineering } \\
\hline Manuscript submitted 27 March 2014 & Date of the defence 16 May 2014 \\
\hline Permission to publish granted (date) 8 April 2014 & Language English \\
\hline
\end{tabular}

\section{Abstract}

Soils that are contaminated with the most recalcitrant organic contaminants, such as high molecular weight polyaromatic hydrocarbons (HMW PAH) and polychlorinated dibenzo-pdioxins and dibenzofurans (PCDD/F), cannot be degraded efficiently by conventional composting. The only available treatment method for these soils, which destroys the contaminants, is combustion at high temperature. This thesis examines three alternative fungal methods to treat these soils: 1) treatment with fungal enzymes, 2) treatment with fungal inoculum, and 3) fungal treatment used as a pre-treatment to improve the energy efficacy in combustion.

Manganese peroxidase (MnP), which belongs to lignin-modifying enzymes (LME), was produced and used to treat PCDD/F-contaminated soil in the laboratory scale. Nevertheless, no degradation with a $\mathrm{MnP}$ preparation was observed, although a substantial amount of $\mathrm{MnP}$ activity was found in the soil still after 10 days of incubation. Both PAH- and PCDD/Fcontaminated soils were treated with fungal inoculum in the laboratory scale. HMW PAHs were degraded significantly more by the fungi than by the indigenous microbes alone in the laboratory experiments, where the PAH concentration of soil was $3500 \mathrm{mg} \mathrm{kg}^{-1}$ (sum of 16 $\mathrm{PAH}$ ). Treatment with Phanerochaete velutina (inoculum) resulted to degradation of $96 \%$ of 4ring PAHs and $39 \%$ of 5- and 6-ring PAHs in three months. With PCDD/F-contaminated soil, no degradation was observed in the control, but the degradation of PCDD/Fs with fungal treatments was significant (P. velutina: $62 \%$, Stropharia rugosoannulata: $64 \%$ of WHO-TEQ value).

Fungal treatment of PAH-contaminated soil was also applied in the field scale ( $2 \mathrm{t}$ ). However, both $P$. velutina (inoculum) and control treatment resulted in equal degradation in soil with lower PAH concentration (1400 $\mathrm{mg} \mathrm{kg}^{-1}$, sum of $16 \mathrm{PAH}$ ): $94 \%$ of the 16 PAHs were degraded in three months. Fungal treatment was even applied as a pre-treatment for contaminated soil with high organic matter content, and which will be later combusted. In the pilot-scale (300 kg), $13 \%$ degradation of the original organic matter content was obtained in 6 months.

To conclude, fungal treatment is reasonable to apply for soils with organic contaminants that cannot be bioremediated by composting. With soils contaminated by chlorinated dioxins, this is always the case, but also PAH-contaminated soils with high total concentration or high proportion of HMW-PAHs. In addition, with fungal treatment the amount of organic matter in the soil can be reduced and the efficacy of the combustion process is improved.

Keywords bioremediation, fungi, lignin-modifying enzymes, polyaromatic hydrocarbons, chlorinated dioxins

\begin{tabular}{lll}
\hline ISBN (printed) 978-952-60-5656-2 & \multicolumn{1}{l}{ ISBN (pdf) 978-952-60-5657-9 } \\
\hline ISSN-L 1799-4934 & ISSN (printed) $1799-4934$ & ISSN (pdf) 1799-4942 \\
\hline Location of publisher Helsinki & Location of printing Helsinki & Year 2014 \\
\hline Pages 124 & urn http://urn.fi/URN:ISBN:978-952-60-5657-9
\end{tabular}



Tekijä

Erika Winquist

Väitöskirjan nimi

Valkolahosienten tarjoamat mahdollisuudet pilaantuneiden maiden biopuhdistuksessa

\begin{tabular}{|c|c|}
\hline Ilkaisija Kemian tekniikan korkeakoulu & \\
\hline Yksikkö Biotekniikan ja kemian tekniikan lai & \\
\hline Sarja Aalto University publication series DOC & IIONS 54/2014 \\
\hline Tutkimusala Bioprosessitekniikka & \\
\hline Käsikirjoituksen pvm 27.03.2014 & Väitöspäivä 16.05.2014 \\
\hline Julkaisuluvan myöntämispäivä 08.04 .2014 & Kieli Englanti \\
\hline
\end{tabular}

\section{Tiivistelmä}

Kaikkein vaikeimmin hajoavilla orgaanisilla yhdisteillä kuten monirenkaisilla polyaromaattisilla hiilivedyillä (PAH) sekä polyklooratuilla dibenzo-p-dioksiineilla ja -furaaneilla $(\mathrm{PCDD} / \mathrm{F})$ pilaantuneita maita ei pystytä tehokkaasti kunnostamaan perinteisellä kompostoinnilla. Ainoa käytössä oleva puhdistusmenetelmä, joka hajottaa pilaavat yhdisteet, on maan poltto korkeassa lämpötilassa. Tämä väitöskirja esittelee kolme vaihtoehtoista valkolahosieniin tai niiden entsyymeihin perustuvaa maanpuhdistusmenetelmää: 1) käsittely sienten tuottamilla entsyymeillä, 2) käsittely sienisiirroksella ja 3) sienisiirroskäsittely esikäsittelynä parantamaan polttoprosessin energiatehokkuutta.

Ligniiniä muokkaaviin entsyymeihin kuuluvaa mangaaniperoksidaasia (MnP) tuotettiin laboratoriomittakaavassa ja käytettiin PCDD/F-pilaantuneen maan puhdistukseen. PCDD/Fpitoisuus ei kuitenkaan muuttunut kokeen aikana siitä huolimatta, että maasta voitiin mitata korkeita MnP-aktiivisuuksia vielä 10 päivää entsyymiliuoksen lisäämisen jälkeen.

Sienisiirrosta käytettiin sekä PAH- että PCDD/F-pilaantuneen maan puhdistukseen laboratoriomittakaavassa. Monirenkaiset PAH-yhdisteet (alkupitoisuus $3500 \mathrm{mg} \mathrm{kg}^{-1}, 16 \mathrm{PAH}$ summa) hajosivat huomattavasti enemmän sienikäsittelyn ansiosta kuin maan luontaisten mikrobien vaikutuksesta. Phanerochaete velutina -sienisiirroksen lisäys hajotti $96 \%$ 4renkaisista sekä 39 \% 5- ja 6-renkaisista PAH-yhdisteistä 3 kk:ssa. PCDD/F-pilaantuneen maan osalta kontrollimaassa ei tapahtunut haitta-aineiden hajoamista, mutta sienikäsittelyn vaikutuksesta merkittävä osa PCDD/F-yhdisteistä hajosi (P. velutina: $62 \%$, Stropharia rugosoannulata: $64 \%$ WHO-TEQ arvosta).

Sienisiiroksen vaikutusta $\mathrm{PAH}-$ pilaantuneen maan puhdistukseen tutkittiin myös kenttämittakaavassa (2 t). Kenttäkokeessa sienisiirroksen lisäys ei tehostanut PAHyhdisteiden hajoamista johtuen todennäköisesti matalammasta alkupitoisuudesta (1400 mg $\mathrm{kg}^{-1}, 16$ PAH summa). PAH-yhdisteet hajosivat molemmissa aumoissa lähes kokonaan $3 \mathrm{kk}: s s a$ (94\%, 16 PAH summa). Sienisiirroskäsittelyä käytettiin lisäksi maan orgaanisen aineen hajottamiseen maassa, jossa oli korkea orgaanisen aineen pitoisuus ja joka oli tarkoitus käsitellä polttamalla. Pilot-mittakaavan $(300 \mathrm{~kg})$ kokeessa $13 \%$ maan orgaanisesta aineesta hajosi $6 \mathrm{kk}: \mathrm{ssa}$.

Yhteenvetona voidaan todeta, että sienisiirroskäsittely on lupaava vaihtoehtoinen käsittelymenetelmä maille, jotka ovat pilaantuneet vaikeasti hajoavilla orgaanisilla yhdisteillä ja joita ei voida käsitellä kompostoimalla. Lisäksi työssä saatiin lupaavia tuloksia sienikäsittelyn käytöstä polttoon menevän maan esikäsittelynä.

Avainsanat biopuhdistus, sienet, ligniiniä muokkaavat entsyymit, polyaromaattiset hiilivedyt, klooratut dioksiinit

ISBN (painettu) 978-952-60-5656-2 ISBN (pdf) 978-952-60-5657-9

\begin{tabular}{lll}
\hline ISSN-L 1799-4934 & ISSN (painettu) $1799-4934$ & ISSN (pdf) 1799-4942 \\
\hline Julkaisupaikka Helsinki & Painopaikka Helsinki & Vuosi 2014 \\
\hline Sivumäärä 124 & urn http://urn.fi/URN:ISBN:978-952-60-5657-9
\end{tabular}





\section{Table of Contents}

Preface

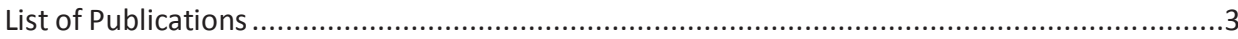

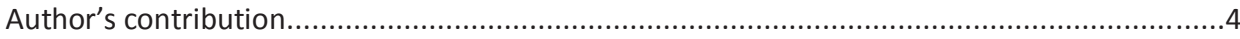

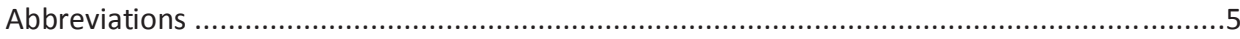

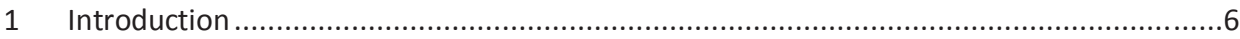

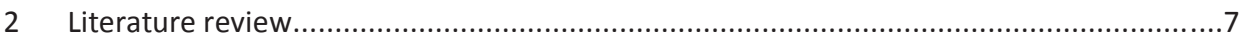

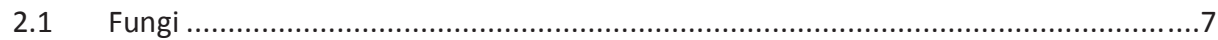

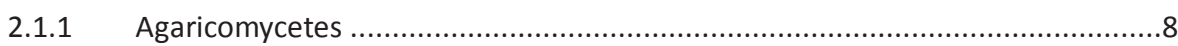

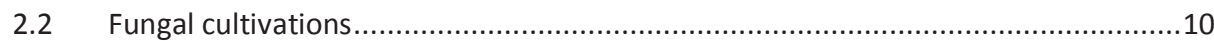

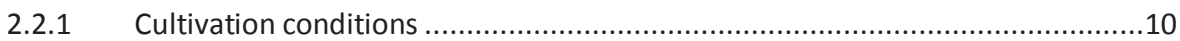

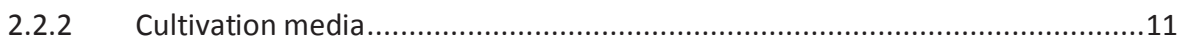

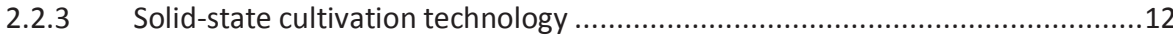

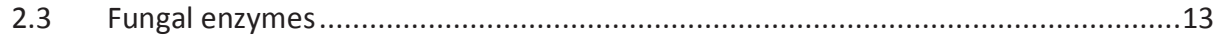

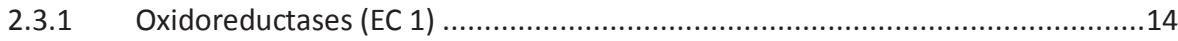

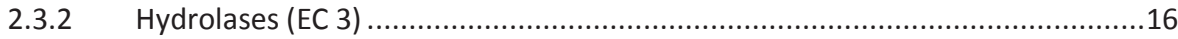

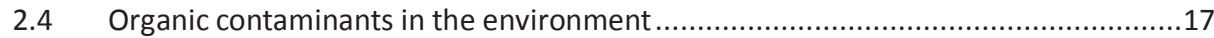

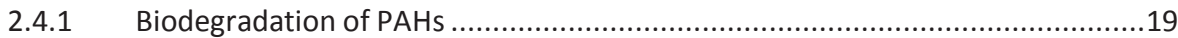

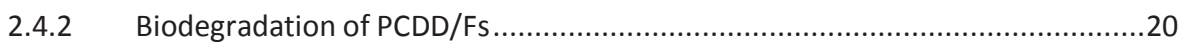

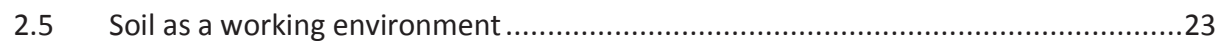

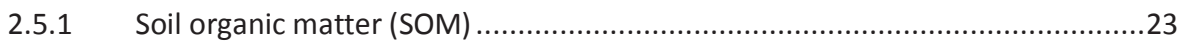

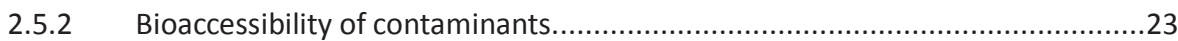

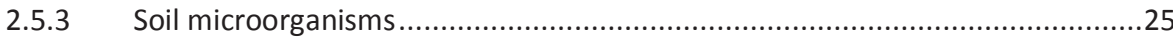

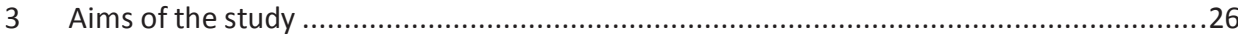

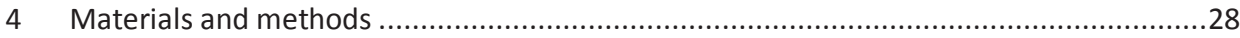

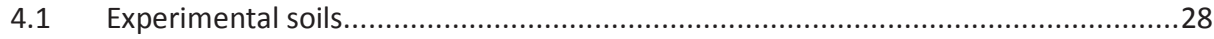

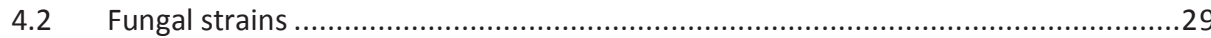

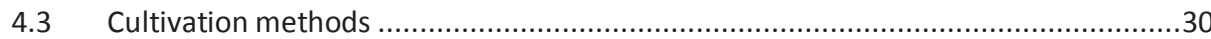

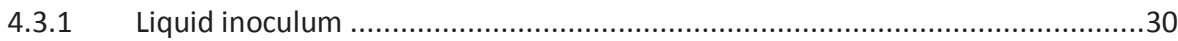

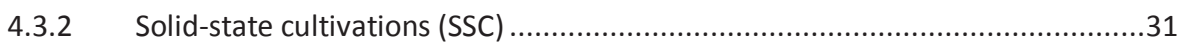

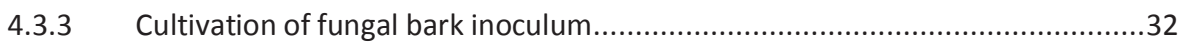




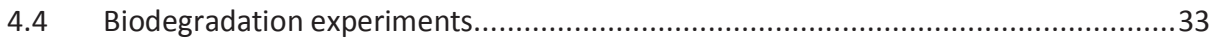

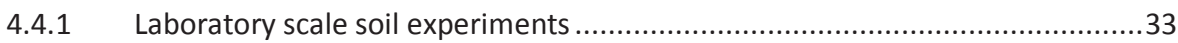

4.4.2 Pilot-scale experiment for degradation of SOM ...............................................36

4.4.3 Field-scale experiment for degradation of PAHs .................................................

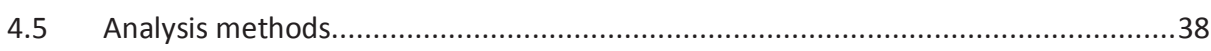

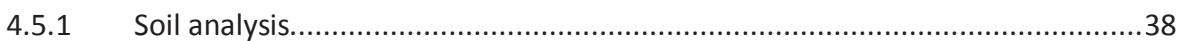

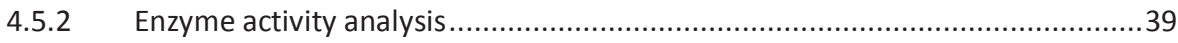

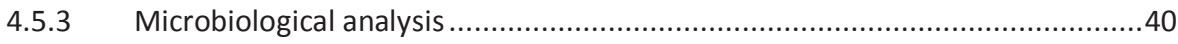

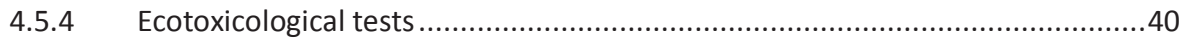

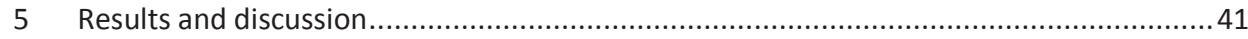

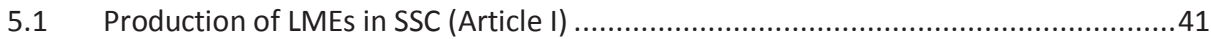

5.2 LME activities in fungal bark inoculum and in PCDD/F-soil (Articles II, III and IV) ......43

5.3 Degradation of SOM and production of $\mathrm{CO}_{2}$ (Article II)........................................44

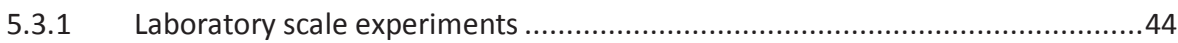

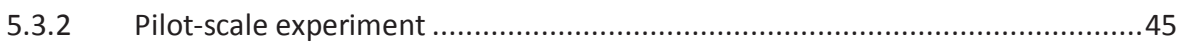

5.4 Degradation of PAHs and PCDD/Fs by fungi (Articles III and IV) ...............................46

5.5 Degradation of PCDD/Fs by fungal enzymes (Article III).........................................50

5.6 Bioremediation of PAH-contaminated soil, field scale experiment (Article IV) ...........51

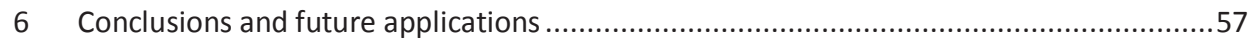

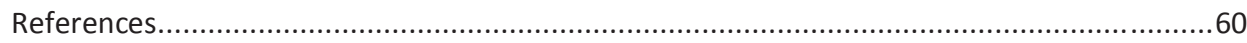

Cover photo by Jean Luc Lamadon: Piptoporus betulinus growing on a silver birch stump. 


\section{Preface}

This thesis work was carried out during the years 2005 - 2013 in the Research group of Bioprocess engineering, Department of Biotechnology and Chemical Technology, Aalto University School of Chemical Technology. The work was mainly funded by three TEKES (the Finnish Funding Agency for Innovation) projects: KFAASI 2004 - 2006 (Industrial applications of solid-state cultivation technology), OMPAS 2007 - 2009 (Degradation of organic matter in contaminated soil), and PIMA-FUN 2009 - 2012 (Bioremediation of contaminated soil with fungi). The two grants for participating international conferences from Maa- ja vesitekniikan tuki ry are also acknowledged.

I am deeply grateful to my supervising professors, Emeritus Professor Matti Leisola and Professor Heikki Ojamo, who made this thesis possible. Thank you for believing in me, providing the facilities, and supporting all of my work during these years. I want to express my warmest thanks also to my thesis advisor Marja Tuomela from University of Helsinki. Thank you for your friendship and all the good advices throughout my whole university career. You teached me to be precise in my writing and not to choose the most obvious way but always question the results. Special thanks also to my thesis advisor Professor Emma Master and the preliminary examiners Jussi Heinonsalo and Professor Liliana Gianfreda. I appreciate the feedback I got from you, it really helped me to improve my thesis.

I want to thank all my former colleagues in the Bioprocess engineering research group, but particularly Ulla Moilanen, Seppo Jääskeläinen, Kalle Salonen, Markus Räsänen, Tero Eerikäinen, and Anne Usvalampi. Ulla, we were almost inseparable during KFAASI-project when we worked together long days at laboratory. Seppo, you were always there for me to help with various equipment to be designed, build or repaired. Kalle, you designed and build a reliable and precise $\mathrm{CO}_{2}$ analyser, which created the basis for my soil experiments. Markus, you worked with me several years starting as a summer trainee, then doing your master's thesis and finally as a fellow research scientist. I could always rely on you and share the problems to be solved. Tero, you supported me in teaching and somehow always managed to stay calm no matter what happened in the machinery hall. Anne, you offered me valuable peer support while we were finishing our thesis at the same time. Luckily, you finished first, so I could always ask what to do next. Without all of you this thesis work would have never realised!

All three research projects were done in collaboration with University of Helsinki and I get to know many people in Professor Annele Hatakka's research group. First of all Annele, you introduced me the exiting world of fungi. Thank you for your help and support during the projects and my thesis. Kari Steffen, Lara Valentín, Festus Anasonye, Beata Kluczek-Turpeinen and Aila Mettälä, you are all co-authors in my articles. Thank you for your superior research work. Kari and Lara, I want to thank you also for your company in the OMPAS project field trips to Jyväskylä and Forssa. It was hard work but we had a great team! Thank you also for the nice atmosphere in the common coffee room. I have always felt to be most welcome while visiting your department. 
In the last project I had the privilege of working with Kirsten Jørgensen, Katarina Björklöf, Eija Schultz and Jaana Sorvari from Finnish Environment Institute, and Thomáš Cajthaml from Institute of Microbiology, Academy of Sciences of the Czech Republic. Even in PIMA-FUN we had field experiments in Forssa and Hausjärvi carried out together with most of you and even more people from your institute, and an excursion to Prague and Zittau with Kirsten and Marja. In addition, Jaana was co-supervisor with me in the master's thesis of Markus. I am grateful to all of you, and not only because of your effort to our common project but because I was able to made so many dear friends.

Finally, I want to thank my family. I owe my deepest gratitude to my parents Pirkko and Hannu who always had faith on me, to my brother Kurt, sister Hanna and brother-in-law Jean Luc who reminded me that there was life outside the university, to my husband Chris for loving me just the way I am, and to my dear children Alvar and Veronica for letting me see the world with children's eyes. Thank you all for bringing love, joy and happiness into my life!

Espoo, April 2014

Erika Winquist

"There is some good in this world, and it's worth fighting for."

- J.R.R. Tolkien, The Two Towers 


\section{List of Publications}

I Winquist, E., Moilanen, U., Mettälä, A., Leisola, M., Hatakka, A., Production of lignin modifying enzymes on industrial waste material by solid-state cultivation of fungi, Biochemical Engineering Journal 42 (2008) 128-132.

II Winquist, E., Valentín, L., Moilanen, U., Leisola, M., Hatakka, A., Tuomela, M., Steffen, K., Development of a fungal pre-treatment process for reduction of organic matter in contaminated soil, Journal of Chemical Technology and Biotechnology 84 (2009) 845850 .

III Anasonye, F., Winquist, E., Kluczek-Turpeinen, B., Räsänen, M., Salonen, K., Steffen, K.T., Tuomela, M., Fungal enzyme production and biodegradation of polychlorinated dibenzo-p-dioxins and dibenzofurans in contaminated soil, Chemosphere (2014), http://dx.doi.org/10.1016/j.chemosphere.2014.03.079.

IV Winquist, E., Björklöf, K., Schultz, E., Räsänen, M., Salonen, K., Anasonye, F., Cajthaml, T., Steffen, K.T., Jørgensen, K.S., Tuomela, M., Bioremediation of PAH-contaminated soil with fungi - from laboratory to field scale, International Biodeterioration \& Biodegradation 86 (2014) 238-247. 


\section{Author's contribution}

I The author designed and executed the experimental work together with the coauthor Ulla Moilanen, except for the screening studies, which were done by Aila Mettälä. The author wrote the article together with Ulla Moilanen and was the corresponding author.

II The author was responsible for the experimental work in the laboratory scale. The design and execution of the experimental work in the pilot scale was done together with the coauthors. The author wrote the article and was the corresponding author.

III The author designed and executed the experimental work together with the coauthors. The author was responsible for the PCDD/F degradation experiments with fungal inoculum, where the $\mathrm{CO}_{2}$ production by fungi was measured. Festus Anasonye executed the screening studies as well as measured the fungal enzyme activities from the soil, and Beata Kluczek-Turpeinen executed the PCDD/F degradation experiments with fungal enzymes. The author wrote the article together with the other authors and is the corresponding author. The author contributed the work equally with the first author Festus Anasonye.

IV The author was responsible for the experimental work in the laboratory scale, except for the screening studies, which were done by Festus Anasonye. The design and execution of the experimental work in the field scale was done together with the other authors. Tomáš Cajthaml was responsible for the bioaccessibility analysis, Katarina Björklöf for the microbiological analysis, and Eija Schultz for the ecotoxicological tests. The author wrote the article together with other authors and was the corresponding author. 


\section{Abbreviations}

APO

BPA

FDS

HMW PAH

HpCDD

$\mathrm{HpCDF}$

LDF

LiP

LME

$\mathrm{MnP}$

OCDD

OCDF

P450

$\mathrm{PAH}$

PCB

PCDD

PCDF

POP

SFE

SMC

SOM

SSC

TBT

TCDD

WHO-TEQ

VP

WRF
Aromatic peroxygenases

Bisphenol A

Fibre and de-inking sludge

High molecular weight PAH, contains at least four benzene rings

$$
\text { Heptachloro-dibenzo- } p \text {-dioxin }
$$

Heptachloro-dibenzofuran

Litter-decomposing fungi

Lignin peroxidase

Lignin-modifying enzymes

Manganese peroxidase

Octachloro-dibenzo-p-dioxin

Octachloro-dibenzofuran

Cytochrome P450 monooxygenase

Polyaromatic hydrocarbon

Polychlorinated biphenyls

Polychlorinated dibenzo- $p$-dioxin

Polychlorinated dibenzofuran

Persistent organic pollutant

Supercritical $\mathrm{CO}_{2}$ extraction

Submerged cultivation

Soil organic matter

Solid-state cultivation

Tributyltin

Tetrachloro-dibenzo-p-dioxin

World Health Organization - Toxic Equivalent

Versatile peroxidase

White-rot fungi 


\section{Introduction}

Ligninolytic fungi, i.e. fungi able to degrade lignin in wood (Chapter 2.1.1), are in focus in this thesis. But what are ligninolytic fungi? They are those mushrooms growing on forest floor (litter-decomposing fungi) or fallen trees (wood-degrading fungi). Yet, the mushrooms we admire for their beauty or collect for cooking are only a small part of the whole organism. What we cannot see is that beneath the soil surface or inside wood they grow as mycelia which form large networks. The largest living organism in the world is Armillaria solidipes (the honey mushroom). Mycelium of the same clone covers $8.8 \mathrm{~km}^{2}$ of forest floor in west coast of USA, close to Canadian border (Malheur National Forest). This giant fungus is estimated to be 2400 years old (Ferguson et al., 2003).

The most important role of ligninolytic fungi in nature is to take part in the global carbon cycle (Carlile et al., 2004). Fungi growing on wood or plant litter are producing extracellular enzymes which degrade wood material, plant litter, as well as soil humic substances (Hatakka, 2001; Hofrichter et al., 1998). With the same enzymes fungi are also able to degrade other recalcitrant organic compounds, such as many toxic chemicals (Tuomela and Hatakka, 2011). Bioremediation with fungi, i.e. mycoremediation, is the topic of this thesis.

Currently, the most common way to handle contaminated soil in Finland is disposal to landfill (Jaakkonen, 2008). Another frequently used practice is stabilization with e.g. bitumen, which allows restricted reuse, for example in various landscaping (Khan et al., 2004). This solution cannot be considered as final because the contaminants are not degraded but only bound to the matrix. According to the principles of sustainable development and the Regulation No $850 / 2004$, given by the European Community, treatment methods which actually destroy the contaminants should always be the first choice, particularly when soil is contaminated with persistent organic pollutants (POP). The only available treatment method for POP-soils, which fulfils these criteria, is combustion at high temperature (over $1100^{\circ} \mathrm{C}$ ). However, the drawbacks of combustion are that it is expensive, energy-intensive, and at present there is not enough capacity in Finland to treat all the POP soils by this means.

Bioremediation offers a sustainable alternative to combustion. Oil-contaminated soils are already successfully remediated by composting (Jørgensen et al., 2000). In this thesis, sawmill soils contaminated with wood preservatives, such as creosote or Ky-5, were studied. Creosote consists mainly of polyaromatic hydrocarbons (PAH). Ky-5 contained chlorophenols as active ingredients but also polychlorinated dibenzo-p-dioxins (PCDD) and dibenzofurans (PCDF) as impurities (Isosaari et al., 2001). In addition to oil hydrocarbons, small molecular mass PAHs and chlorophenols are degraded during a well optimized composting process (Antizar-Ladislao et al., 2004; Laine and Jørgensen, 1997). However, high molecular weight (HMW) PAHs, containing at least four benzene rings, and PCDD/Fs are not easily degraded by bacteria because of their poor bioavailability and chemically stable structure (Johnsen et al., 2005; Laine et al., 1997).

By using ligninolytic fungi, it could be possible to widen the applicability of bioremediation even to POP soils (Harms et al., 2011; Lamar and White, 2007). Fungi have several advantages 
over bacteria. Due to their hyphal growth mode they can form mycelial networks, which they can use to transport water, nutrients and electron acceptors within mycelia. Unlike bacteria they can also grow though air-filled pores and penetrate soil aggregates. Fungi secrete extracellular lignin-modifying enzymes (LME) that are able to diffuse to the immobile contaminants adsorbed to soil particles. Furthermore, because these enzymes have low specificity they are able to degrade a wide range of organic compounds and mixtures of various chemicals. However, even though the results from laboratory scale studies have been promising, there are only few reports from successful field scale studies (Steffen and Tuomela, 2010). The purpose of this thesis was to find out how the addition of fungal inoculum or fungal enzymes could enhance the bioremediation process and what are the limitations and bottlenecks of these technologies.

\section{Literature review}

\subsection{Fungi}

Fungi are a diverse group of organisms including mushrooms, moulds and yeast. At present 100000 fungal species are described and it is estimated that there may exist from one to five million species (Myllys et al., 2013). Before 1960s fungi were classified as plants, but at present they are recognized as a separate kingdom and in the 1990s genomic research, including DNA and RNA analyses, revealed that fungi are actually more closely related to animals than plants. The classification of fungi is continuously changing when new DNA data is obtained. In the beginning of 2013 the genome structure of 222 fungi were known (Myllys et al., 2013). Based on the current knowledge, the kingdom of fungi is divided into seven phyla: Microsporidia, Blastocladiomycota, Neocallimastigomycota, Chytridiomycota, Glomeromycota, Ascomycota, and Basidiomycota (Hibbett et al., 2007). Typical mushrooms belong to the phylum Basidiomycota and further in the class Agaricomycetes. Many moulds and yeasts belong to the phylum Ascomycota.

Fungi can be defined as non-photosynthetic hyphal eukaryotes and related forms (Carlile et al., 2004). Hyphal growth forms branches and this network is called mycelium. The hypha is typically divided by cross-walls into compartments, which may contain several nuclei. Such compartments are equivalent to the cells of other organisms. The cell walls of fungi are rigid and the main polymer in the cell wall composition is chitin. Fungi are chemotrophs, obtaining energy from chemicals, and heterotrophs, using organic compounds as the source of carbon. They secrete extracellular enzymes to degrade polymers outside the cell and absorb the released nutrients in to the cell through the cell membrane. They are also able to transport water and nutrients inside the hypha (Carlile et al., 2004).

A generalized view of the life cycle of the Agaricomycetes is presented in Figure 1. They produce sexual spores (basidiospores) in their fruiting bodies, but also asexual spores (oidia) 
can be formed from the mycelium with some species, e.g. Phlebiopsis gigantea (Pratt et al., 2000). When suitable substrate and growth conditions are present, haploid $(n)$ spores germinate and primary mycelium is formed. Primary mycelium can fuse with other primary mycelium of compatible mating type and form dikaryotic $(n+n$, unfused nuclei from different parents) secondary mycelium. This secondary mycelium produces fruiting bodies where fusion of two haploid nuclei occurs in basidia to give diploid nuclei $(2 n)$. Meiosis follows and each basidium bears four haploid basidiospores (Carlile et al., 2004).

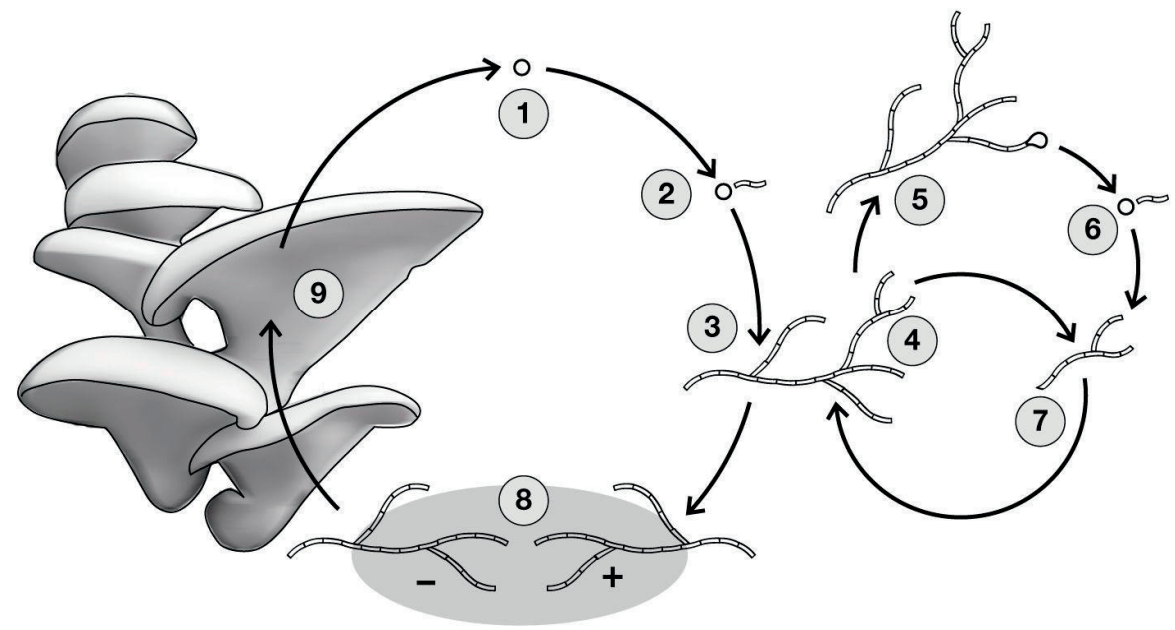

Figure 1. A generalized view of the life cycle of the Agaricomycetes (after Case, 2013; drawing by Kurt Berger): 1) Basidiospores are released from fruiting bodies, 2) Basidiospore germinates to produce hyphae (primary mycelium), 3) Mycelium grows, 4) Hyphal fragment breaks off from mycelium, 5) Asexual spores (oidia) are formed from mycelium, 6) Oidia germinates to produce hyphae, 7) Fragment or hyphae grows to produce new mycelium, 8) Two hyphae fuse and dikaryotic secondary mycelium is formed, 9) Secondary mycelium produces fruiting bodies.

\subsubsection{Agaricomycetes}

The typical mushrooms belong to the phylum Basidiomycota and in the class Agaricomycetes. There are 17 orders within the class Agaricomycetes but most of the ones studied in this work belong to the orders Agaricales or Polyporales (Myllys et al., 2013). Members of the order Polyporales grow on wood and their fruiting bodies, which can be annual or perennial, are often very hard. Members of the order Agaricales have annual fruiting bodies with stalk and cap and many of them are edible, such as Agaricus bisporus (cultivated white button mushroom or champignon mushroom) and Stropharia rugosoannulata (wine cap stropharia or burgundy mushroom), which is also used for bioremediation. 
The Agaricomycetes can also be divided into three ecophysiological groups: wood-degrading fungi, litter-decomposing fungi and mycorrhizal fungi, based on their habitat and role in nature (Steffen and Tuomela, 2013). Many wood-degrading fungi belong to the order Polyporales and many litter-decomposing and mycorrhizal fungi belong to the order Agaricales.

\section{Wood-degrading fungi}

The natural environment for wood-degrading fungi is wood. However, many wood-degrading species, e.g. members of the genera Phanerochaete, Pleurotus and Trametes, may also survive in soil if suitable substrates are available (Baldrian, 2008). Some of them are able to grow in living trees (pathogenic fungi), but most of them grow on dead trees (saprotrophic fungi). Their role in natural ecosystem is to decompose wood and recycle the nutrients of wood. Wooddegrading fungi are further divided into white-rot and brown-rot fungi. Wood decay mechanisms of both groups rely on enzymes (radical formation), low $\mathrm{pH}$, and the production of organic acids (Carlile et al., 2004).

White-rot fungi (WRF) degrade all components in wood: cellulose, hemicellulose and lignin (Figure 2). White-rotted wood residue is white, soft and fibrous, because of the removal of dark coloured lignin. White-rot and related litter-decomposing fungi are the only organisms capable of mineralizing lignin efficiently (Hatakka, 2001). These two groups are also called ligninolytic fungi. Some WRF remove lignin first and attack cellulose later. These fungi, selectively degrading lignin while using hemicelluloses as an energy source, are promising for biopulping applications. In biopulping, the pre-treatment of wood chips with WRF reduces the refining energy consumption in mechanical pulping (Hakala et al., 2004). Other applications are found in forestry. Phlebiopsis gigantea inoculated to stumps prevents the growth of Heterobasidion annosum, which causes root and butt rot in conifers, and Chondrostereum purpureum is applied to prevent coppice formation (Vartiamäki et al., 2008; Pratt, 2000).

Brown-rot fungi degrade cellulose and hemicellulose, and modify lignin. Brown-rotted wood residue is dark, shrink and typically broken into cubical fragments. The brown colour indicates the presence of modified lignin in wood (Hatakka, 2001). In addition to degradation of wood, brown-rot fungi together with litter-decomposing fungi are involved in formation of humic substances, where the most important precursor is lignin (Steffen and Tuomela, 2013).

\section{Litter-decomposing fungi}

The natural environment for litter-decomposing fungi (LDF) is the top soil layer where they degrade plant litter material. Litter is composed of dead organic material such as leaves, needles, small branches, bark pieces, insect and animal debris (Steffen and Tuomela, 2013). LDF are classified also as WRF since they produce lignin-modifying enzymes (LME) and whiterot from litter. However, they are not as efficient lignin-degraders as wood-degrading WRF. The distinction between WRF and LDF is not exact. LDF might be more suitable to bioremediation applications than WRF because of their better ability to grow in the soil (Baldrian, 2008; Valentín et al., 2009). 


\section{Mycorrhizal fungi}

An important part of the role of fungi in ecosystems is the capture of mineral nutrients. The growth of most plants is enhanced by the presence of mycorrhizal fungi, which form close associations with plant roots. In these associations both parties benefit from it. Mycorrhizal fungi take up nutrients used by the plant, such as phosphorus and nitrogen, and the plant supplies the fungus carbon compounds, mainly hexose sugars (Carlile et al., 2004). Many mycorrhizal fungi are important as edible mushrooms. In Finland the first experiments to cultivate truffles (Tuber aestivum) started in Juva in 2006 (Shamekh et al., 2007). The cultivation of some other species, e.g. Cantharellus cibarius (golden chanterelle), is also possible but the market price has to be high enough before it is economically feasible (Hall et al., 2003). Mycorrhizal fungi have also been studied in the production of tree seedlings (Korkama et al., 2007). With the help of existing appropriate mycorrhizal fungi, more seedlings survive after planting. In addition, they have been even studied in rhizosphere remediation to degrade various persistent organic contaminants (Harms et al., 2011). Mycorrhizal fungi use several hydrolytic enzymes for the degradation of organic matter in soil to be able to mobilize nitrogen. They also secrete phenol-oxidizing enzymes, such as tyrosinase and laccase, which contribute humification and detoxification processes in soil (Singh, 2006).

\subsection{Fungal cultivations}

Most industrial cultivation processes are submerged cultivations (SMC), where microorganisms are cultivated in stirred tank bioreactors. SMC has a long history in the wine and beer fermentations and later in the industrial production of antibiotics (Carlile et al., 2004). Although yeast and moulds grow well in SMC, the ligninolytic fungi, which are in focus in this thesis, prefer solid-state cultivation (SSC) in most applications (Rodriguez Couto and Sanromán, 2005).

\subsubsection{Cultivation conditions}

Oxygen: Almost all fungi are aerobes and grow poorly or not at all in the absence of oxygen. However, few anaerobic cellulolytic fungi are known which grow in rumen (Carlile et al., 2004).

Water: Water is essential for all life forms. Between $70-90 \%$ of the cell mass is composed of water and all biochemical reactions, that take place inside the cell, occur in the water phase. However, since most fungi also need oxygen, which has low solubility in water, fungi generally grow better in cultivation medium where free water is limited, i.e. it is mostly absorbed by the substrate (Hölker et al., 2004).

Temperature: Most fungi have a maximum temperature for growth at $30-40^{\circ} \mathrm{C}$ and a minimum a few degrees above the freezing point of water. Some thermophilic fungi can also grow in composts, where the temperature can rise over $40^{\circ} \mathrm{C}$ (Carlile et al., 2004). 
$\mathrm{pH}$ : Most fungi prefer slightly acidic growth conditions, e.g. $\mathrm{pH}$ 4-7. In fungal cultivations $\mathrm{pH}$ is usually kept as low as possible to avoid bacterial contamination, because low $\mathrm{pH}$ favors fungal growth (Carlile et al., 2004).

Light: The fruiting bodies of most Agaricomycetes, including Lentinula edodes (shiitake, oak mushroom) and Pleurotus ostreatus (oyster mushroom), require light to develop properly (Jang et al., 2013). Fruiting-body formation of Coprinus cinereus is perfectly synchronized to the light-dark rhythm fixed by the normal day-night cycle. To initiate the fruiting body development, several environmental signals are needed, of which dark and light periods are the most important (Kües, 2000). Jang et al. (2013) studied the effect of color of light emitting diode (LED) on development of fruiting body of Hypsizygus marmoreus (shimeji) and found out that the cultivation under blue LED $(475 \mathrm{~nm})$ resulted in the formation of fruiting bodies with good features, e.g. high ergosterol level.

\subsubsection{Cultivation media}

The natural substrates for fungi are various biomasses, mainly plant materials. Since these materials are principally composed of cellulose, they are rich in carbon, but poor in nitrogen and phosphorus. Accordingly, fungi have adapted to growth in comparatively low nitrogen media, where an optimal carbon : nitrogen -ratio for growth is 10:1. In addition, fungi are able to reuse the nitrogen stored in their biomass (Ulmer et al., 1983). Older hyphae are autolysed and nitrogen, which is released, is transported to the growing hyphae (Carlile et al., 2004).

Carbon $(C)$, hydrogen $(H)$, oxygen $(O)$, nitrogen $(N)$, sulphur $(S)$, phosphorus $(P)$, magnesium $(\mathrm{Mg})$ and potassium $(\mathrm{K})$ are required by all organisms in large amounts. $\mathrm{C}, \mathrm{H}$ and $\mathrm{O}$ are provided in the form of organic compounds, water, and oxygen. An organic form of carbon is always required, as all fungi are heterotrophic. Nitrogen can be provided to most fungi in the form of inorganic nitrogen compounds, usually as ammonium or nitrate salts. Also S, P, Mg and $\mathrm{K}$ can be provided as salts, e.g. magnesium sulphate $\left(\mathrm{MgSO}_{4}\right)$ and potassium phosphate $\left(\mathrm{KH}_{2} \mathrm{PO}_{4}\right)$ (Carlile et al., 2004). In addition to major nutrients, trace elements are required as cofactors for enzymes and other functional proteins. $\mathrm{Fe}, \mathrm{Cu}, \mathrm{Ca}, \mathrm{Mn}, \mathrm{Zn}$ and $\mathrm{Mo}$, are needed in nano- to micro-molar concentrations. Certain trace elements such as copper and zinc become toxic for some fungi at levels only a few times greater than those required for optimal growth (Baldrian, 2003).

One of the advantages in solid-state cultivation (SSC) is that various waste materials from agriculture and food industry or even from forestry and paper processing industry can be used as substrates (Article I). Often these waste materials represent a complex medium, which provide not only carbon but sufficient amounts of all other nutrients as well. However, before using in a cultivation process, many of these waste materials need a pretreatment, such as 1) grinding or milling to increase the surface area, 2) soaking to soften and adjust the water content and 3) steaming or autoclaving to kill unwanted organisms and partially degrade the structure. Particularly important is to optimize the particle size of the substrate. It needs to be small enough to provide some homogeneity to the medium and to increase the surface area of 
the particles where the mycelium is growing. However, the medium needs to remain porous rather than form a tightly packed cake, to allow uniform oxygen distribution as well as dissipation of the carbon dioxide and heat generated by fungal metabolism (Moilanen et al., 2014).

In Article I, oat husks were found to be a promising waste material for lignin-modifying enzyme (LME) production. Oat husks are formed as by-product in flour mills. In addition to polysaccharides, which the fungus uses as a source of energy and carbon, oat husks contain also lignin, which acts as an inducer for the production of LMEs. In the following Articles II - IV, Scots pine (Pinus sylvestris) bark was used as a substrate in the production of fungal inoculum for bioremediation purposes. Pine bark is a by-product from pulp, paper and timber production and it is composed mainly of lignocellulose. It is also a selective growth substrate, since it contains phenolic extractives with antimicrobial properties, and thus it enables the use of semi-aseptic growth conditions (Valentín et al., 2010).

\subsubsection{Solid-state cultivation technology}

SSC is defined as a cultivation method where a microorganism is grown on solid material without free water. This technology is particularly suitable for fungal cultivations because the cultivation conditions in SSC are similar to the natural living conditions of fungi. Advantages of SSC are better oxygen transfer and no need for mixing during cultivation, which offers static growth conditions without shear forces. In addition, SSC resembles fed-batch cultivation with slow sugar supply, preventing catabolite repression (Viniegra-Gonzáles et al., 2003; Hölker et al., 2004).

Various bioreactor types have been used in SSC processes, including tray bioreactors, unmixed and mixed packed beds, rotating drums, and fluidized beds (Mitchell et al., 2000; Durand, 2003). The tray bioreactor represents the simplest design. The moistened and inoculated substrate is poured on perforated trays, which are incubated in a certain temperature and humidity. Scale-up of a tray bioreactor can be done by increasing the number of trays, but not by increasing the thickness of the substrate cake, because the temperature inside a thick cake will increase too much. In the packed bed bioreactor the substrate is placed on a perforated plate through which conditioned air is blown. The forced aeration improves the heat removal and the oxygen supply. In addition, mixing can be combined to the packed bed type bioreactor, if the fungus tolerates mixing. With mixing temperature gradients are avoided and a more homogenous system is achieved. In the rotating drum bioreactor the mixing is gentle, but the ratio of working volume to the total volume is small. In fluidized beds, mixing is accomplished by forced aeration with a large air flow, but requires a complicated design and a lot of energy for aeration.

Compared to the submerged cultivation (SMC), the solid medium contains less water, but there is a gas phase between the particles. In SMC, the main challenge is the transfer of oxygen to microorganisms because oxygen has low solubility in water. In SSC, oxygen transfer is seldom a problem and energy requirements for aeration and mixing are lower than in SMC. 
On the contrary, in SSC problems arise from the poor thermal conductivity of air compared to water, and the main challenge in SSC bioreactor design is how to remove heat produced by fungal metabolism during the cultivation (Mitchell et al., 2000; Durand, 2003). Other problems in SSC are mass transfer and homogenous addition of liquids for the adjustment of $\mathrm{pH}$ and moisture content. Some kind of mixing is required at least for homogenous inoculation. However, if these challenges in bioreactor design can be solved, SSC technology could reduce the bioreactor volume and produce more compact waste streams, because the reduced amount of water in the system increases substrate concentrations as well as product concentrations (Hölker et al., 2004).

Traditionally, SSC has been used in the production of various Asian foods, such as soy sauce, and edible fungi (Rodriguez Couto and Sanromán, 2005). Currently, the most "high-tech" use of aseptic SSC processes is in the commercial production of biological plant protection agents. These products are based on fungal spores, which are often not produced under SMC conditions (Virtanen et al., 2008; de Vrije et al., 2001). However, SSC has potential particularly in the utilisation of organic wastes from agriculture and forestry as raw materials for valueadded products, e.g. enzymes. Several studies have reported higher enzyme yields with fungi in SSC than in liquid cultivation (Fujian et al., 2001; Viniegra-Gonzáles et al., 2003).

\subsection{Fungal enzymes}

In general, enzymes are divided into six classes based on the reaction they catalyse: oxidoreductases (EC 1), transferases (EC 2), hydrolases (EC 3), lyases (EC 4), isomerases (EC 5) and ligases (EC 6) (http://www.chem.qmul.ac.uk/iubmb/enzyme/, 10.2.2014). Most fungal extracellular enzymes belong to two enzyme classes: oxidoreductases and hydrolases (Lundell and Mäkelä, 2013). Oxidoreductases catalyse the oxidation or reduction reactions, i.e. transfer of hydrogen or oxygen atoms or electrons from one substrate to another. Hydrolases catalyse hydrolysis reactions, i.e. the cleavage of chemical bonds by the addition of water (http://www.cazy.org/, 10.2.2014).

Fungi produce extracellular enzymes to degrade various polymers in their growth environment. The structure of plant cell wall lignocellulose is presented in Figure 2. Oxidoreductases are involved in lignin degradation. However, fungi cannot utilize lignin as a source of energy or carbon. The reason for lignin degradation is to break down the complex lignocellulose structure in plant cell wall to be able to use cellulose and hemicellulose for growth (Leisola et al., 2012). Further breakdown of cellulose and hemicellulose is catalysed with hydrolases. 


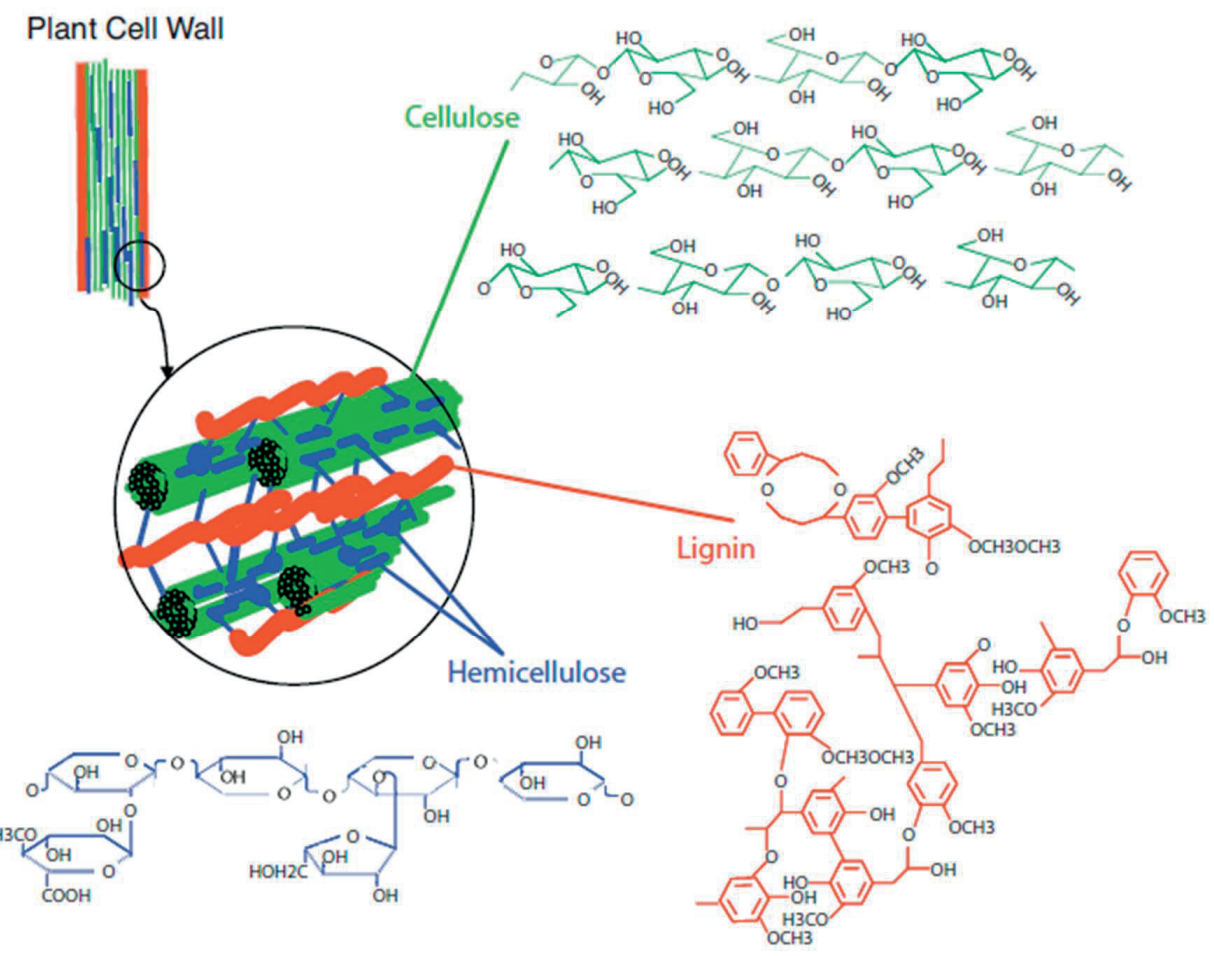

Figure 2. Structure of lignocellulose in plant cell wall

(http://biofuel.webgarden.com/sections/blog/pictures-for-lignocellulose, 6.11.2013).

\subsubsection{Oxidoreductases (EC 1)}

Lignin is formed from the random polymerization of phenyl propanoid units and it is the most complex natural polymer. LMEs are extracellular non-specific oxidative enzymes (Table 1), which are able to degrade lignin structure through radical reactions (Hatakka, 2001; RuizDueñas and Martínez, 2009). In addition to lignin, they can oxidize a wide range of organic compounds with structural similarities to lignin including soil humic substances (Hofrichter et al., 1998), but also organic contaminants (Tuomela and Hatakka, 2011).

Laccases are phenol oxidases that contain four copper ions per molecule. Laccases catalyze the reduction of oxygen to water, which is accompanied by oxidation of various phenols (Table 1 ). Laccases have rather low redox potential, but in the presence of redox mediators, such as 2,2'azino-bis(3-ethylbenzothiazoline-6-sulphonic acid) (ABTS) and 1-hydroxybenzotriazole (HBT), also other organic compounds are oxidized (Thurston, 1994; Tuomela and Hatakka, 2011). 
Table 1. Most relevant fungal extracellular oxidative enzymes in environmental applications (Harms et al., 2011; Lundell and Mäkelä, 2013; Tuomela and Hatakka, 2011).

\begin{tabular}{|c|c|c|}
\hline Enzyme activity & Reaction mechanism & Occurrence in fungi \\
\hline $\begin{array}{l}\text { Laccase } \\
\text { (EC 1.10.3.2) }\end{array}$ & $\begin{array}{l}\text { - } \mathrm{O}_{2} \text {-dependent one-electron } \\
\text { oxidation of various phenols } \\
\text { - extended substrate range in the } \\
\text { presence of redox mediators } \\
\text { - mostly acidic and rarely neutral } \\
\text { pH range }\end{array}$ & $\begin{array}{l}\text { Basidiomycota and } \\
\text { Ascomycota, } \\
\text { in most WRF and LDF }\end{array}$ \\
\hline $\begin{array}{l}\text { Manganese peroxidase (MnP) } \\
\text { (EC 1.11.1.13) }\end{array}$ & $\begin{array}{l}\text { - } \mathrm{H}_{2} \mathrm{O}_{2} \text {-dependent one-electron } \\
\text { oxidation of } \mathrm{Mn}^{2+} \text { to } \mathrm{Mn}^{3+} \text {, chelated } \\
\mathrm{Mn}^{3+} \text { oxidizes phenolic compounds } \\
\text { - acidic } \mathrm{pH} \text { range }\end{array}$ & $\begin{array}{l}\text { Basidiomycota, } \\
\text { common in WRF and LDF }\end{array}$ \\
\hline $\begin{array}{l}\text { Lignin peroxidase (LiP) } \\
\text { (EC 1.11.1.14) }\end{array}$ & $\begin{array}{l}\text { - } \mathrm{H}_{2} \mathrm{O}_{2} \text {-dependent one-electron } \\
\text { oxidation of aromatic compounds } \\
\text { - extended substrate range in the } \\
\text { presence of the redox mediator } \\
\text { veratryl alcohol } \\
\text { - acidic pH range }\end{array}$ & $\begin{array}{l}\text { Basidiomycota, } \\
\text { only in few WRF }\end{array}$ \\
\hline $\begin{array}{l}\text { Versatile peroxidase (VP) } \\
\text { (EC 1.11.1.16) }\end{array}$ & $\begin{array}{l}\text { - reaction mechanism of both } \\
\mathrm{MnP} \text { and LiP } \\
\text { - acidic } \mathrm{pH} \text { range }\end{array}$ & $\begin{array}{l}\text { Basidiomycota, only in } \\
\text { Pleurotus sp., Bjerkandera sp. } \\
\text { and Trametes versicolor }\end{array}$ \\
\hline $\begin{array}{l}\text { Coprinopsis cinerea peroxidase } \\
\text { (CiP) (EC 1.11.1.7) }\end{array}$ & $\begin{array}{l}\text { - } \mathrm{H}_{2} \mathrm{O}_{2} \text {-dependent one-electron } \\
\text { oxidation of various phenols } \\
\text { - acidic and alkaline } \mathrm{pH} \text { range }\end{array}$ & $\begin{array}{l}\text { Basidiomycota, } \\
\text { only in C. cinerea }\end{array}$ \\
\hline $\begin{array}{l}\text { Dye-decolorizing peroxidase } \\
\text { (DyP) (EC 1.11.1.x) }\end{array}$ & $\begin{array}{l}\text { - } \mathrm{H}_{2} \mathrm{O}_{2} \text {-dependent one-electron } \\
\text { oxidation of organic compounds } \\
\text { - decolorizes Reactive Blue } 5 \\
\text { - additional hydrolysing activity } \\
\text { - acidic pH range, also very low pH }\end{array}$ & $\begin{array}{l}\text { Basidiomycota and } \\
\text { Ascomycota }\end{array}$ \\
\hline
\end{tabular}

MnPs, LiPs and VPs (Table 1) are peroxidases, which have heme (protoporphyrin IX containing $\mathrm{Fe}^{2+}$-ion as a central atom) as their prosthetic group (Tuomela and Hatakka, 2011). LiP was first isolated from Phanerochaete chrysosporium culture in 1983 (Tien and Kirk, 1983; Glenn et al., 1983) and MnP was characterized two years later from the same species (Glenn and Gold, 1985). MnPs catalyze the oxidation of $\mathrm{Mn}^{2+}$ ions to $\mathrm{Mn}^{3+}$ ions, which are stabilized by chelation with organic acids. These $\mathrm{Mn}^{3+}$-organic acid complexes oxidize further phenolic compounds (Wariishi et al., 1992). LiPs catalyze the one-electron oxidation of both phenolic and nonphenolic aromatic compounds (Hatakka, 1994). VPs are hybrid peroxidases which have the catalytic activities of both MnP and LiP (Ruiz-Dueñas and Martínez, 2009). Some fungi produce also non-ligninolytic heme-containing peroxidases, such as Coprinopsis cinerea peroxidase (CiP) and dye-decolorizing peroxidases (DyP). CiP oxidizes phenols and smaller dye molecules whereas DyP is also capable of oxidizing complex dye molecules (Tuomela and Hatakka, 2011). All peroxidases require $\mathrm{H}_{2} \mathrm{O}_{2}$ as an electron acceptor.

Accessory enzymes, which take part in lignin degradation, include aryl alcohol oxidase (AAO, EC 1.1.3.7) and glyoxal oxidase (GLOX). These enzymes are involved for example in hydrogen 
peroxide $\left(\mathrm{H}_{2} \mathrm{O}_{2}\right)$ production (Tuomela and Hatakka, 2011). Furthermore, intracellular cytochrome $\mathrm{P} 450$ monooxygenases are probably also involved in lignin degradation. The P450 enzymes catalyse the monooxygenation of various lipophilic compounds and they may work together with peroxidases in degradation of lignin and other organic compounds (Bezalel et al., 1997; Subramanian and Yadav, 2009). The extracellular aromatic peroxygenases (APO) have catalytic similarity to intracellular P450s. However, APOs have been described so far only for Agrocybe aegerita and Coprinellus radians (Aranda et al., 2010).

LMEs are potential industrial enzymes for several applications. These include applications in pulp and paper processing industries (e.g. biobleaching, biopulping, pitch removal, functionalization of lignocellulosic materials, and modification of wood fibers) (Reid and Paice, 1994; Singh et al., 2010; Gutierréz et al., 2006; Kudanga et al., 2011), improvement of the enzymatic hydrolysis of lignocellulosic substrates (Moilanen et al., 2011), as well as bioremediation of contaminated soils and effluents (Rao et al., 2010; Wu et al., 2005). In bioremediation applications, laccases and MnPs are the key fungal enzymes. Almost all WRF produce laccase and the production of $\mathrm{MnP}$ is more widespread among WRF than that of LiP. Notably, LiP activity has been detected from the soil only in a few experiments (Wang et al., 2009). Furthermore, VP has so far been found only in Pleurotus sp., Bjerkandera sp. and Trametes versicolor (Tuomela and Hatakka, 2011; Carabajal et al., 2013).

\subsubsection{Hydrolases (EC 3)}

Fungi utilize various extracellular hydrolytic enzymes for the degradation of cellulose and hemicellulose from wood or plant litter. Cellulose is a linear homopolymer composed of glucose units linked together with $\beta$-1,4-linkages. Single cellulose chains are connected together with hydrogen bonds to form microfibrils. Efficient degradation of cellulose requires three different types of cellulases, namely endoglucanase (EC 3.2.1.4), exoglucanase (cellobiohydrolase, EC 3.2.1.91) and $\beta$-glucosidase (EC 3.2.1.21), which act synergistically. Endoglucanases hydrolyse $\beta$-1,4-glucosidic linkages in non-crystalline sections of the cellulose chain internally, which results in a decrease in the chain length and an increase in the number of free ends. Exoglucanases degrade cellulose starting from free ends by splitting off cellobiose, a disaccharide composed of two glucose units. Finally, $\beta$-glucosidase hydrolyses cellobiose to glucose (Viikari and Álen, 2011). Recently, a new type of accessory enzyme for the break-down of cellulose has been discovered (Horn et al., 2012). The lytic polysaccharide monooxygenase (also known as GH61 enzyme) catalyses the oxidative cleavage of crystalline cellulose and increases its accessibility to classical hydrolytic enzymes (cellulases).

Hemicelluloses are branched heteropolysaccharides composed of various hexoses (D-glucose, D-mannose, D-galactose), pentoses (D-xylose, L-arabinose, D-arabinose), deoxyhexoses (Lrhamnose, L-fucose) and uronic acids (4-O-methyl-D-glucuronic acid, D-galacturonic acid, Dglucuronic acid). The composition of hemicelluloses varies with different plants, i.e. softwood, hardwood and annual plants. Due to the wide variety in the composition of hemicelluloses, numerous enzymes are needed for their break-down. The two most common hemicelluloses are xylan (in hardwood) and glucomannan (in softwood). Xylan has homopolymeric backbone 
chains of 1,4 -linked $\beta$-D-xylopyranose units. Besides xylose, xylan contains on average one glucuronic acid side group attached to every tenth xylopyranose unit (Álen, 2011). Glucomannan is branched heteropolysaccharide containing $\beta$-D-mannopyranose and $\beta$-Dglucopyranose units in the backbone and $\alpha$-D-galactopyranose units as side groups. The ratio of galactose: glucose: mannose in soft wood glucomannan is 1:2:7 (Álen, 2011). Endoxylanases

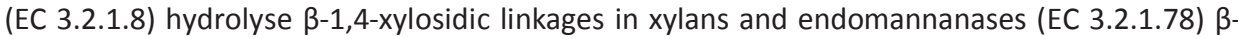
1,4-linkages in mannans. In addition, exoenzymes, such as $\beta$-xylosidase (EC 3.2.1.37) and $\beta$ mannosidase (EC 3.1.1.25), are needed for further hydrolysis of short oligomeric compounds produced by endoenzymes. Hemicelluloses can also be acetylated. These acetyl substitutes are removed by acetyl-xylan-esterase (EC 3.1.1.72). Finally, there is a variety of side-group cleaving enzymes (Viikari and Álen, 2011).

\subsection{Organic contaminants in the environment}

Organic compounds, that are hazardous for environment and human health, resist environmental degradation, accumulate in organisms along food chain, and are capable of long-range transport, are classified as Persistent Organic Pollutants (POPs) by The Stockholm Convention (Stockholm Convention 2001, www.pops.int). After its fifth meeting (May 2011), 22 organic compounds are currently classified as POPs. They include industrial chemicals and by-products formed in industrial processes, such as polychlorinated biphenyls (PCB), polychlorinated dibenzo-p-dioxins (PCDD), polychlorinated dibenzofurans (PCDF), hexachlorobenzene (HCB), carcinogenic polyaromatic hydrocarbons (PAHs), and certain brominated flame-retardants. In addition, POPs include also pesticides, such as dichlorodiphenyltrichloroethane (DDT), and some organometallic compounds, e.g. tributyltin (TBT).

PCBs were widely used as coolants and insulating fluids in transformers and capacitors. Due to their widespread use, PCBs are common contaminants in many former industrial soils. PCBs are problematic to degrade by bacteria because this leads to the formation of toxic chlorobenzoic acids (CBAs), which tend to accumulate in soils contaminated with PCBs. However, ligninolytic fungi are able to further degrade CBAs while simultaneously transforming PCBs (Čvančarová et al., 2012).

Recently the awareness of the so called "emerging contaminants" has increased. These are chemicals that are currently discovered in natural waters although previously they were not detected. They include plasticizers (such as bisphenol A, BPA), flame-retardants, pesticides, pharmaceuticals and personal care products among others. The risk to human health and the environment associated with their presence is not yet fully understood (Kabiersch, 2013). They typically disrupt the endocrine system or cause other long-term effects already in very low concentrations, e.g. BPA has estrogenic activity even at pico- to nano-molar concentrations (vom Saal and Hughes, 2005). BPA is known for its estrogenic activity since 1993 (Krishnan et al., 1993), but it is still used to produce polycarbonate plastics and epoxy resins, and it can be found in many consumer products such as water bottles and coatings inside food and beverage cans. BPA may leach out from these materials during washing with hot water or in 
alkaline or acidic conditions. Moreover, it is not fully broken down in wastewater treatment processes and thus wastewater effluents can spread BPA into the aquatic environment. With the help of LMEs BPA and other emerging contaminants could be degraded in municipal wastewaters. Kabiersch et al. (2011) studied the degradation of BPA with MnP and noticed that 90 min treatment with MnP resulted in $98 \%$ degradation of BPA and $100 \%$ reduction of estrogenic activity.

Long-range transport is the most important source for pollutants in the arctic environment where the natural attenuation is extremely slow (Mannio et al., 2002). The production and use of many POPs are already prohibited or restricted, and so the sources of long-range transport are previously used chemicals and already existing environmental pollution. Therefore, it is absolutely necessary to treat all POP soils with such treatment methods that actually destroy the contaminants. Fungi or fungal enzymes may provide new methods to treat contaminated soils or waste waters. There is potential to use fungal mycelia to treat POP soils, including PCB-, PAH- and PCDD/F-contaminated soils (Harms et al., 2011), and fungal enzymes to clean up effluents, e.g. degrade emerging contaminants in municipal wastewaters, synthetic dyes in textile industry wastewaters, and lignin in pulp mill wastewaters (Husain, 2006; Wu et al., 2005)

(Figure 3).

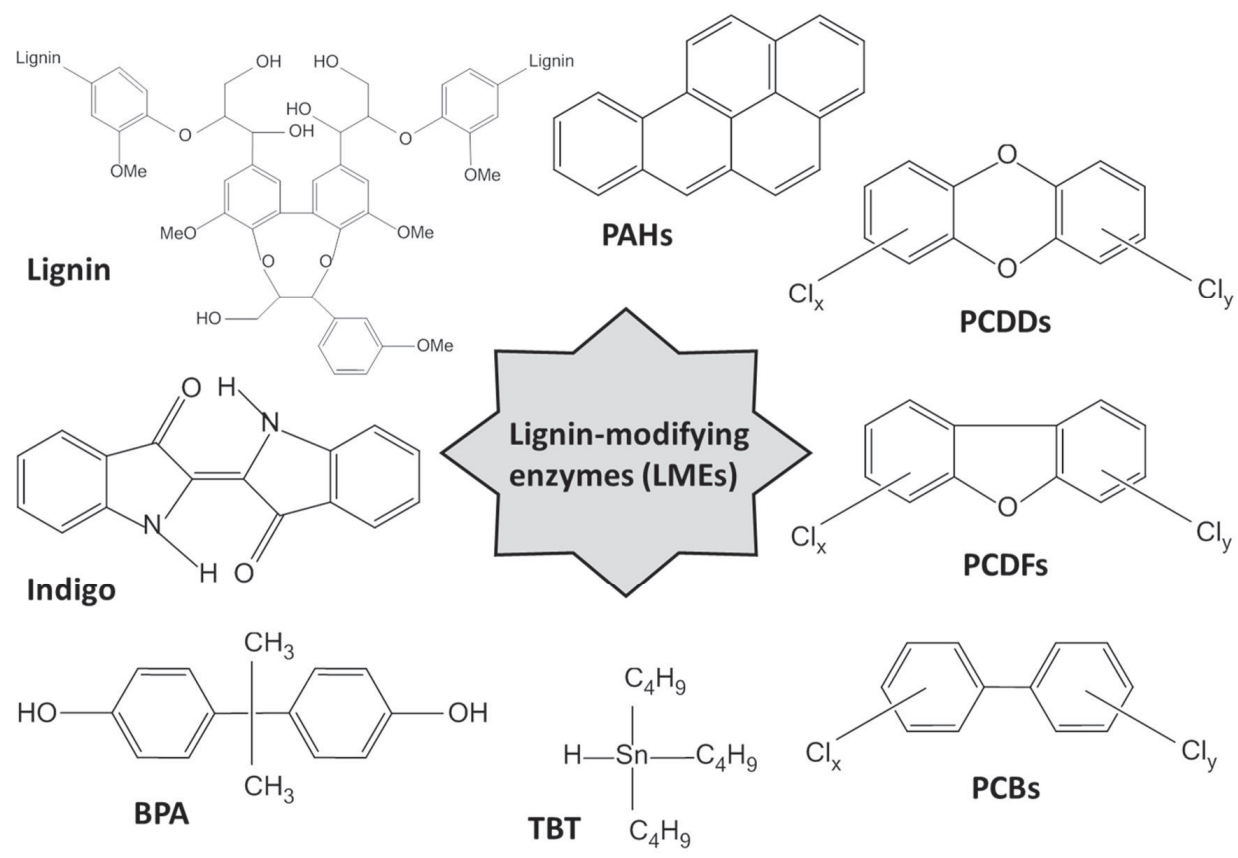

Figure 3. Examples of various organic contaminants which can be degraded by LMEs. 


\subsubsection{Biodegradation of PAHs}

PAHs are present in crude oil and coal and they are also formed by incomplete combustion of carbon-containing fuels, including fossil fuels, wood or other biomass. PAH contamination can be either diffuse contamination in urban surface soils, which receive a continuous input of pyrogenic PAHs from air emissions, or "hotspot" contamination from a point source like gasworks soil or oil-polluted soil (Johnsen and Karlson, 2007). The PAH contamination in sawmill soil originates from coal-tar creosote, which consists almost wholly of PAHs, and was commonly used to preserve and waterproof crossties and power line poles. Altogether 16 PAHs are of special concern and these are listed by the United States Environmental Protection Agency (US EPA) (Article IV: Table 3). Benzo(a)pyrene with five benzene rings is considered as the most carcinogenic PAH-compound. PAHs are resistant to microbial degradation because of their low water solubility and complex structure with two or more fused benzene rings (Antizar-Ladislao et al., 2004).

Johnsen and Karlson (2007) investigated the diffuse PAH contamination in surface soils and noticed that phenanthrene, fluoranthene, and pyrene can be degraded by soil microorganism, whereas, benzo(a)anthracene and benzo(a)pyrene are examples of more recalcitrant high molecular weight (HMW) PAHs that are biodegraded very slowly in soil. Bacteria degrade PAH compounds typically by an assimilative process where they gain carbon and energy from the contaminant for growth, which leads to mineralization of the compound (Kästner et al., 1994; Haderlein et al., 2006). Bacteria generally use intracellular dioxygenase enzymes for the degradation of PAHs (Johnsen et al. 2005). The aerobic bacterial degradation of PAH compounds is initiated by an oxygenation of the ring structure to form a cis-dihydrodiol, which can be further degraded to carbon dioxide and water via catechol formation (Figure 4).

Gram-negative bacteria, such as Burkholderia ( $\beta$-proteobacteria), can easily degrade 2- or 3ring PAHs with dioxygenases, whereas gram-positive bacteria, such as Mycobacterium, are more efficient in degrading HMW PAHs (Johnsen et al., 2005). Mycobacterium sp. degrades PAHs by an intracellular detoxification process. PAHs are first oxidized by P450 enzymes to arene oxides and then further converted to trans-dihydrodiols by epoxide hydrolase. Alternatively, the arene oxides can be non-enzymatically rearranged to phenols, which can be additionally conjugated with sulphate, glucuronic acid or glucose (Figure 4). In addition, the non-ligninolytic fungus Cunninghamella elegans uses the same pathway when it oxidizes various PAHs to phenols (Cerniglia, 1992).

Ligninolytic fungi are able to degrade and even mineralize PAHs and the mechanism is thought to be similar to that of lignin degradation (Sanglard et al., 1986). The oxidation of PAHs is catalyzed by peroxidases or laccases and results in the formation of PAH-quinones that can be further oxidized (Figure 4). LMEs might have an important role in the initial attack on HMW PAHs in soil (Sack et al., 1997; Harms et al., 2011). Since LMEs are extracellular, they are able to diffuse effectively to the highly immobile HMW PAHs. The resulting metabolites are more water soluble, and thus more bioaccessible. The formed compounds can be substrates for many bacteria (Sack et al., 1997), but they may also be further degraded by fungal intracellular enzymes, such as cytochrome P-450 monooxygenase (Pozdnyakova, 2012). When the 
degradation of several PAHs by Irpex lacteus was studied, structures of some of the metabolites suggested involvement of both LMEs and cytochrome P-450 monooxygenase (Cajthaml et al., 2002a; 2006). In addition to mineralization, a significant fraction of PAHs is incorporated into humic substances during bioremediation (Kästner et al., 1994; 1999).

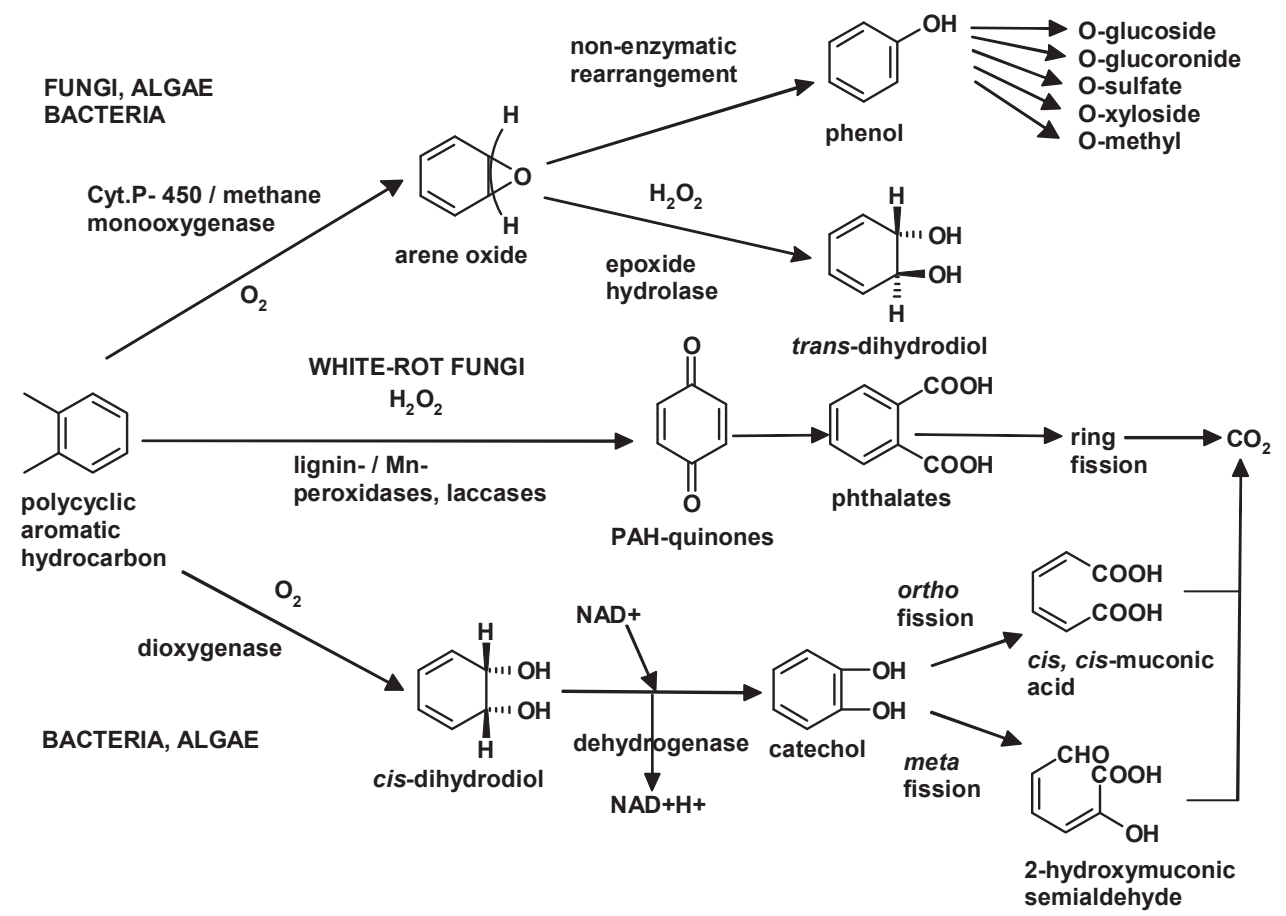

Figure 4. Proposed degradation pathways of polyaromatic hydrocarbons (PAHs) by bacteria and fungi (after Cerniglia and Sutherland, 2001; figure courtesy of Kari Steffen).

\subsubsection{Biodegradation of PCDD/Fs}

Polychlorinated dibenzo-p-dioxins (PCDD) and dibenzofurans (PCDF) are classified as Persistent Organic Pollutants (POPs) and belong to the most toxic compounds among them (Weber et al., 2008). PCDD/Fs contain two aromatic rings with one to eight chlorine atoms (Figure 5). The toxic congeners have chlorine groups in all of the $2,3,7,8$ positions (7 PCDDs and 10 PCDFs), and the most toxic congener is 2,3,7,8-tetrachlorodibenzo-p-dioxin (2,3,7,8-TCDD) (Srogi, 2008). The toxicity of other congeners is compared to that of 2,3,7,8-TCDD by multiplying their concentration with a Toxic Equivalency Factor (TEF) (Article III, Table 4). The total toxic concentration (expressed as World Health Organization -Toxic Equivalent, WHO-TEQ) can be calculated by adding up all the 2,3,7,8-TCDD equivalents of all the individual congeners. $\mathrm{PCDD} / \mathrm{Fs}$ are naturally degraded very slowly due to their chemically stable structure and poor 
bioavailability. PCDD/Fs are highly hydrophobic and become tightly adsorbed on soil particles and absorbed into organic matter in soils and sediments (Srogi, 2008).

PCDD/Fs are almost exclusively produced as by-products in industrial processes, such as incineration of municipal waste, chlorine bleaching of paper and pulp, and the manufacture of some pesticides, herbicides and fungicides (Srogi, 2008). In Finland, the main source of PCDD/F contamination has been the production and use of a chlorophenol containing wood preservative (Ky-5) during 1940 - 1984. Ky-5 had a specific combination of chlorophenols: 2,3,4,6-tetrachlorophenol (55\%), 2,4,6-trichlorophenol (36\%), and pentachlorophenol (7\%). Additionally, PCDD/Fs were found as impurities in Ky-5 (Isosaari et al., 2001). Most of the chlorophenols in these contaminated sawmill soils have volatilized, leached, or biodegraded over the past several decades. In contrast, the PCDD/Fs still persist in the top soil with heptaand octachlorodibenzofurans $(1,2,3,4,6,7,8-\mathrm{HpCDF}$ and OCDF) as the main congeners responsible for the contamination (Isosaari et al., 2001). In addition to sawmill soils, severe PCDD/F contamination is also found in Kymijoki River sediments (Weber et al., 2008). The Ky-5 production plant was situated along the river and a fire in the plant in 1960 caused a large spill. In addition, washing of the production line during normal operation resulted in PCDD/F containing effluents (Kaakkois-Suomen ELY, 2012).

The biodegradation pathways of PCDD/Fs are much less studied than that of PAHs, probably because PCDD/Fs are more persistent to microbial degradation. Most of the evidence for aerobic biodegradation of PCDD/Fs has been obtained with lower chlorinated dioxins (Field and Sierra-Alvarez, 2008). Aerobic bacteria from the genera of Sphingomonas, Pseudomonas and Burkholderia have aromatic ring hydroxylating dioxygenase enzymes, but they are usually only able to degrade mono-, di- and trichloro-dibenzo-p-dioxins and -furans (Habe et al., 2001; Nojiri and Omori, 2002) (Figure 5). One exception is the Sphingomonas wittichii strain RW1, which was shown to transform also higher chlorinated dioxins (Nam et al., 2006).

Anaerobic bacteria, e.g. Dehalococcoides species, are able to convert higher chlorinated dioxins to lower chlorinated dioxins through reductive dechlorination by a dehalogenase enzyme (Bunge et al., 2003) (Figure 5). In nature, dehalogenase and dioxygenase enzymes might also work sequentially. Yoshida et al. (2005) studied the degradation of chlorinated dioxins in polluted river sediments under anaerobic conditions. The best results were obtained at the surface of the sediment layer, because lower chlorinated congeners formed from reductive dechlorination were subsequently oxidized by aerobic bacteria.

Certain white-rot fungi (WRF) have been shown to degrade all congeners of PCDD/Fs, even the ones with maximum amount of chlorine atoms (Takada et al., 1996, Kamei et al., 2009; Valentín et al., 2013). In addition to extracellular LMEs, some WRF have also intracellular P450 (Hiratsuka et al., 2005; Stella et al., 2013). LMEs attack chlorinated dioxins cometabolically under aerobic conditions. Valli et al. (1992) proposed a pathway for the oxidation of 2,7-DCDD by whole cultures or by purified LiP of $P$. chrysosporium (Figure 5). Fungal P450 enzymes are probably also involved in the degradation of lignin and they may work together with peroxidases (Hiratsuka et al., 2005). Possibly, the degradation of chlorinated dioxins by WRF is initiated by P450 enzymes and extracellular enzymes are involved with later stages of degradation. However, the degradation of PCDD/Fs by a fungal P450 has so far only been 
shown with 2,3-DCDD (Kasai et al., 2010). In addition, 2,3-DCDD and 2,3,7-TriCDD have been degraded with a bacterial P450 from Bacillus megaterium (Sulistyaningdyah et al., 2004).

a<smiles>Clc1cc2c(c(Cl)c1Cl)Oc1c(cc(Cl)c(Cl)c1Cl)O2</smiles><smiles>Clc1cc2c(cc1Cl)Oc1ccccc1O2</smiles><smiles>CCC</smiles><smiles>Cc1ccc2c(c1)Oc1cccc(Cl)c1O2</smiles>

b<smiles>CCCCCCOc1ccccc1Oc1ccc(Cl)cc1</smiles><smiles>C[C@@]12Oc3cc(Cl)ccc3OC1=CC=C[C@@H]2O</smiles><smiles>Oc1cc(Cl)ccc1Oc1cccc(O)c1O</smiles>

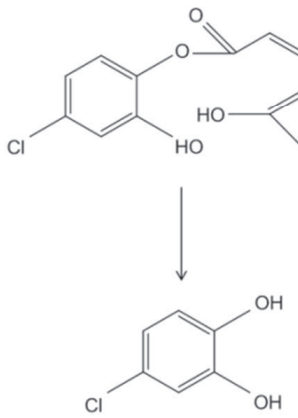

C<smiles>CCOC(C)(C)C(C)(C)C</smiles><smiles>Oc1ccc(O)c(O)c1</smiles>
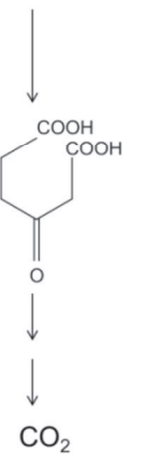

Figure 5. Proposed degradation pathways of chlorinated dioxins (PCDD): a) 1,2,3,4-TeCDD by pure culture of Dehalococcoides sp. (dehalogenase in anaerobic conditions) (Bunge et al., 2003), b) 2-CDD by aerobic bacteria (angular dioxygenase) (Habe et al., 2001; Nojiri and Omori, 2002), c) 2,7-DCDD by Phanerochaete chrysosporium (lignin peroxidase) (Valli et al., 1992). 


\subsection{Soil as a working environment}

Soil is an extremely heterogenous matrix. The composition of the soil affects all soil processes, including microbial growth and biodegradation of organic contaminants. Soil can be roughly classified into two soil types: organic soil, which has more than $20 \%$ of organic matter, and mineral soil, which can be further divided into unsorted and sorted sediments (Hartikainen, 1992). Basically, three main properties affecting the soil composition are 1) particle size, 2) mineral composition and 3) amount of organic matter. Particle size of mineral soil varies from clay (grain size $<2 \mu \mathrm{m}$ ) through silt and sand to gravel and rocks. It gives a foundation to the size and shape of air pores inside the soil, as well as the penetration of air and water. Soil structure provides also the space and the surface for microorganisms. Mineral composition determines the soil pH. In Finland most soils are acidic because the typical rocks are acidic and the occurrence of limestone is very limited (Hartikainen, 1992). Amount of organic matter relates to the amount of organic carbon available for microorganisms and to the water holding capacity of the soil.

\subsubsection{Soil organic matter (SOM)}

SOM is composed of litter (i.e. plant and animal residues), decomposition products from litter, and humic substances, which are synthesized from litter decomposition products by microorganisms. Litter, together with living plants, serves as carbon and energy source for soil microorganisms, whereas humic substances maintain the chemical and physical properties of the soil (Hartikainen, 2003). Humic substances are structurally very complex and large molecules, which are resistant to microbial degradation. They have high water holding capacity and many diverse functional groups, which can participate in various types of chemical reactions (Hartikainen, 2003). Hydrophobic organic contaminants, such as PAHs and PCDD/Fs, can be attached to humic substances both by sorption and covalent bonding (Srogi, 2008; Kästner et al., 1999). Sorption takes place mainly on the surface of humic substances and, in some cases, in the internal binding sites of the molecule. Although sorption reduces the bioavailability of the contaminants, the reaction is not irreversible and the compounds might be later released. In contrast, the humification of contaminants is an important detoxification process. Covalent bonds are most likely to be associated with contaminants that are similar to humic substances, i.e. they have phenolic structure. The resulting bonds lead to almost irreversible incorporation of contaminants into the humic substances (Semple et al., 2003).

\subsubsection{Bioaccessibility of contaminants}

Contaminants enter the soil mainly by spillage and leakage, or by atmospheric deposition. Part of the contaminants is lost by volatilization, leaching or biodegradation, and part is retained within the soil (Semple et al., 2003) (Figure 6). In "aged contamination" volatile, water soluble and easily biodegradable fractions are no more present and the remaining contaminants are 
attached to soil particles through sorption (adsorption to solid surfaces, absorption in organic matter), physical entrapment (immobilization in micropores) and covalent bonding (oxidative coupling to phenolic compounds, i.e. humification) (Kästner et al., 1999).

For a successful bioremediation process, the microorganisms, or their enzymes, need to be in physical contact with the organic contaminant. Both properties of the soil and the type of the contaminant determine bioavailability and bioaccessibility of the contaminant in the soil (Harms, 2011). Previously the terms bioaccessible and bioavailable were not differentiated and both features were referred as bioavailable. However, the current usage of these terms is more explicit. Bioavailability represents the fraction that is taken up by the cells, followed by toxic effects or biodegradation by intracellular mechanisms. The term bioaccessibility, often also called environmental availability, considers the fraction that is potentially available for biota in soils. From the risk assessment point of view, bioaccessibility is more important than the total concentration, because toxic effects can be attributed to a contaminant only when it is accessible (Čvančarová et al., 2013).

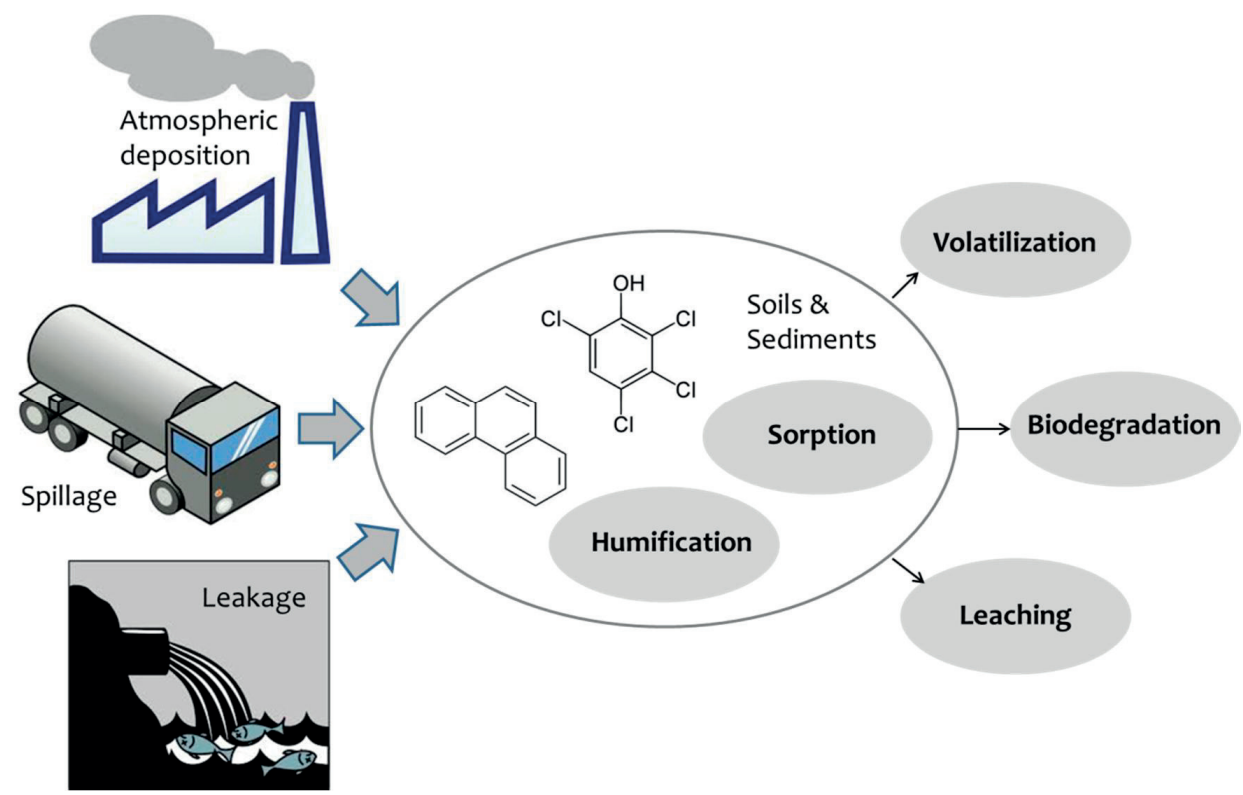

Figure 6. Sources and fates of model organic contaminants (phenanthrene and 2,3,4,6tetrachlorophenol) in soils and sediments. 


\subsubsection{Soil microorganisms}

Soil is a complex ecosystem with many diverse macro- and microorganisms. Microorganisms, i.e. bacteria, archae and fungi, are responsible for $80-90 \%$ of all the chemical reactions occurring in soil and the number of microbial cells per gram of soil can reach $10^{10}$ (Nannipieri et al., 2003; Torsvik and Øvreås, 2002). In addition, the amount of microbial biomass is large: in a temperate grassland soil the bacterial and fungal biomass was estimated to be $1-2$ and $2-5$ t ha ${ }^{-1}$, respectively (Nannipieri et al., 2003). Less than $1 \%$ of the microorganisms have been cultivated and characterized, and thus the microbial diversity in soil is still to a large extent unexplored. However, at present more information about the soil population is obtained through methods based on analyses of ribosomal RNA genes (rDNA) (Torsvik and Øvreås, 2002).

Soil is generally poor in nutrients and energy sources and contains "hot spots", zones of increased biological activity, such as plant and animal debris, animal manure, and rhizosphere (Nannipieri et al., 2003). The availability of nutrients is a critical factor for wood-degrading fungi to be able to survive in soil (Baldrian, 2008). In soil there is competition for nutrients and living space between soil microorganisms. This has to be considered when selecting a suitable fungal strain for bioremediation: it needs to be able to compete with indigenous microorganisms. Even nematodes (worm-like animals) can attack fungal mycelia, but also vice versa, some fungi can attack nematodes (Valentín et al., 2009).

The presence of indigenous microorganisms may also benefit the mycoremediation process. Inoculated as well as naturally occurring fungi may work together with indigenous bacteria. When growing in soil, saprotrophic fungi decompose organic matter and small molecular mass nutrients are released outside the cell. In addition to being available for their producers, they serve as nutrients also for other soil microorganisms. Šnajdr et al. (2011) found a positive correlation between bacterial and fungal biomass in soil. Fungi also increase the bioavailability of immobile and unevenly distributed contaminants for bacterial degradation both by increasing bacterial mobility and by transporting various contaminants within fungal mycelia. Bacteria are able to move in liquid films around fungal hyphae and thus cross air-filled pores and penetrate soil aggregates (Kohlmeier et al., 2005). Fungi may also take up and actively transport contaminants closer to the bacteria inside their hyphae via cytoplasmic streaming (Furuno et al., 2012).

The conditions in soil during full scale bioremediation process are not aseptic. However, by choosing a tolerant fungal strain the existence of naturally occurring micro-organisms can benefit the process. Bacteria may work together with fungi successively or the role of fungi might even be to assist the bacterial degradation. 


\section{Aims of the study}

In this study the potential of ligninolytic fungi and their enzymes were evaluated for bioremediation purposes. New treatment methods are needed particularly for soils that are contaminated with the most recalcitrant contaminants, such as high molecular weight polyaromatic hydrocarbons (HMW PAH) and polychlorinated dibenzo- $p$-dioxins and dibenzofurans (PCDD/F), which cannot be degraded efficiently by conventional composting. The only current treatment method, which fulfills the requirement for soils contaminated with persistent organic pollutants (POP) (EC Regulation No 850/2004), is combustion at high temperature (over $1100^{\circ} \mathrm{C}$ ). However, the drawbacks of combustion are that it is expensive, energy-intensive, and currently there is not enough capacity in Finland to treat all the contaminated soils by combustion.

In Finland, there are approximately 900 sawmill sites, of which $80 \%$ are abandoned and $20 \%$ need urgent remediation due to the presence of contaminants in residential or groundwater area (Pyy et al., 2013). Sawmill soils are often contaminated with PAHs, chlorophenols, PCDD/Fs, and heavy metals (Kitunen et al. 1987). This study examines three alternatives to treat these soils: 1) with lignin-modifying enzymes (LMEs) (Article I \& III), 2) with fungal inoculum (Article III \& IV), and 3) by fungal treatment as a pre-treatment to improve the energy efficacy in combustion (Article II) (Figure 7). Contaminated soils with high organic matter content, such as sawmill soils, are particularly problematic to treat with combustion because the capacity of the combustion process is negatively correlated with the organic matter content of the soil (Valentín et al., 2009). Thus, this process could be improved and batch size increased by reducing the amount of soil organic matter (SOM) (Article II).

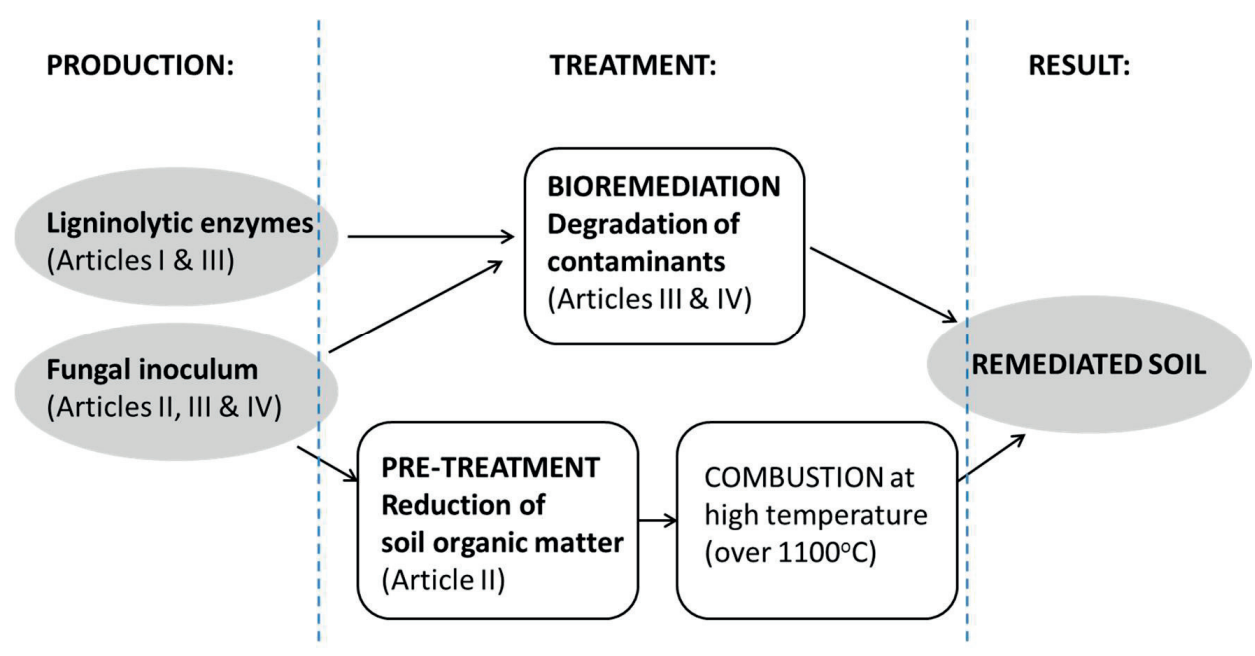

Figure 7. Fungal applications in the treatment of contaminated soils. 
The aims of the study were:

1. Production of LMEs

2. Production of fungal inoculum

3. Development of a fungal pre-treatment method to decrease the soil organic matter content

4. Development of a fungal bioremediation method for contaminated soils

The structure of the study is presented in Table 2. The starting point for this thesis was to study the production of lignin-modifying enzymes (LMEs) by fungi (Article I \& III). Currently, only laccase is produced commercially and peroxidases are only available for research purposes due to their high cost and low production scale (Dupont, 2013; fibre2fashion, 2009). One solution for a feasible commercial production of peroxidases could be the use of SSC with various waste materials from agriculture and food industry as substrates (Article I).

Another approach for environmental applications is to produce fungal inoculum and use the living mycelia as a source of LMEs. The quality of the fungal inoculum was evaluated by measuring the LME activities from the fungal inoculum (Article II \& IV) as well as from the contaminated soil after inoculation (Article III). The fungal activity and production of $\mathrm{CO}_{2}$ during fungal growth in contaminated soil was followed and the degradation of SOM and contaminants by fungi was studied (Article II, III \& IV). Finally, a field scale experiment was performed with PAH-contaminated soil (Article IV).

In this thesis, soil organic matter (SOM) played a central role as it was used as a carbon source for fungal growth. In Article II, the contaminated soil had high organic matter content and the aim was to reduce the amount of organic matter by fungal metabolism prior to combustion. In Article IV, on the contrary, composted green waste was added to the contaminated sandy soil to ensure good fungal growth.

Table 2. Research topics included in the articles of the thesis

\begin{tabular}{lcccc}
\hline Research topic & Article I & Article II & Article III & Article IV \\
\hline Production of LMEs & $\mathrm{x}$ & & $\mathrm{x}$ & $\mathrm{x}$ \\
$\mathrm{LME}$ activities in fungal bark inoculum and in & & $\mathrm{x}$ & $\mathrm{x}$ & $\mathrm{x}$ \\
contaminated soils & $\mathrm{x}$ & $\mathrm{x}$ & $\mathrm{x}$ \\
Fungal activity and production of $\mathrm{CO}_{2}$ & & $\mathrm{x}$ & $\mathrm{x}$ \\
Degradation of SOM & & & $\mathrm{x}$ \\
Degradation of contaminants by fungi & & & \\
Degradation of PCDD/Fs in vitro & & & \\
Field scale experiment & & & \\
\hline
\end{tabular}




\section{Materials and methods}

\subsection{Experimental soils}

In all experiments non-sterile soil, from sites with a history of contaminating activities, were used. This gives an extra challenge for the research work. Firstly, contaminants are less bioaccessible in soil than in liquid because they are bound to humic substances. Secondly, contaminants in aged contaminated soil are even less bioaccessible than in artificially contaminated, "spiked" soil. Thirdly, in non-sterile soil there is competition between inoculated and indigenous microorganisms. However, these conditions were chosen to simulate the conditions in field scale.

\section{Soils rich in organic matter}

Soils from sawmill as well as shooting range areas typically have high organic matter content due to sawdust and other small wood particles in the soil (Table 3). In contrast to sawmill soils, shooting range soils cannot be treated with combustion, due to the lead contamination, and the only current solution is disposal to landfill. However, the SOM content is also a problem in landfilling because it enhances the microbial activity and results in methane formation. For disposal to hazardous waste landfill the limit for SOM is $10 \%$ (loss on ignition at $550^{\circ} \mathrm{C}$ ) (Ympäristöministeriön ohje 2/2007). Therefore, also shooting range soil was selected for the experiments.

Both sawmill soils, Sawmill A and Sawmill B, originated from the same contaminated area, where chlorophenols had been used, and contained over $40 \%$ of carbon (Article II, Table 1). Shooting range soil was contaminated mainly with lead and PAH compounds (mainly fluoranthene and pyrene) and contained $16 \%$ organic carbon. In this study, it can be assumed that the analysed total carbon content represented well the organic carbon content of the soil, because the soil was acidic and thus contained very little carbonates. Therefore, we were also able to calculate the maximum $\mathrm{CO}_{2}$ production (originating from the organic matter degradation) based on the total carbon content (Equation 4, Chapter 4.4.1).

\section{PAH- and PCDD/F-contaminated soils}

PAH-contaminated soil $\left(6000 \mathrm{mg} \mathrm{kg}^{-1}\right.$ ) from one former sawmill area and PCDD/Fcontaminated soils from three former sawmill areas were used in laboratory experiments (Table 3). In all of these areas there had been well documented sawmilling activity for several decades. In addition to sawmill soils, commercially available composted green waste (Helsinki Region Environmental Services Authority, Finland) was used to dilute the PAH-contaminated soil. 
According to Finnish legislation (Valtioneuvoston asetus 214/2007), soil is classified as contaminated if the concentration of a contaminant exceeds the so called "lower base line value". The lower base line value is the maximum concentration of a contaminant in soil for regular use of soil, e.g. in residential area. The upper base line value is the maximum concentration for less sensitive use of soil, e.g. in industrial area. For PAHs the lower base line value is $30 \mathrm{mg} \mathrm{kg}^{-1}$ and the upper base line value $100 \mathrm{mg} \mathrm{kg}^{-1}$ (sum of $16 \mathrm{PAHs}$ ). For PCDD/Fs the values are $100 \mathrm{ng} \mathrm{kg}^{-1}$ and $1500 \mathrm{ng} \mathrm{kg}^{-1}$ (WHO-TEQ), respectively.

Table 3. Properties of contaminated and control soils used in the laboratory experiments

\begin{tabular}{|c|c|c|c|c|c|c|}
\hline Experiment & Soil & $\mathrm{pH}$ & $\begin{array}{c}\text { Dry } \\
\text { matter } \\
(\%)\end{array}$ & $\begin{array}{c}\text { Organic } \\
\text { matter } \\
(\% \mathrm{dm})\end{array}$ & $\begin{array}{c}\text { PAHs } \\
\left(\mathrm{mg} \mathrm{kg}^{-1}\right)\end{array}$ & $\begin{array}{l}\text { PCDD/Fs } \\
\left(\mathrm{ng} \mathrm{kg}^{-1}\right)^{\mathrm{a}}\end{array}$ \\
\hline \multirow{3}{*}{$\begin{array}{l}\text { Degradation } \\
\text { of SOM } \\
\text { (Article II) }\end{array}$} & Sawmill A & 4.3 & $34 \pm 2^{b}$ & $82 \pm 2^{b}$ & & $60-70$ \\
\hline & Sawmill B & 4.3 & $29 \pm 1$ & $82 \pm 3$ & & $60-70$ \\
\hline & Shooting range ${ }^{c}$ & 3.9 & $64 \pm 2$ & $28 \pm 2$ & 150 & \\
\hline \multirow{4}{*}{$\begin{array}{l}\text { Degradation } \\
\text { of PAHs } \\
\text { (Article IV) }\end{array}$} & Oil-cont. soil, screening ${ }^{d}$ & $n d^{e}$ & nd & nd & 220 & \\
\hline & PAH-cont. soil & 5.8 & $93 \pm 2$ & 4 & 6000 & \\
\hline & Diluted PAH-soil (1:1) & 6.6 & $76 \pm 2$ & 10 & 3500 & \\
\hline & Composted green waste & 7.4 & $59 \pm 2$ & 16 & & \\
\hline \multirow{6}{*}{$\begin{array}{l}\text { Degradation } \\
\text { of PCDD/Fs } \\
\text { (Article III) }\end{array}$} & Sawmill 1, screening & nd & nd & nd & & $7500-36000$ \\
\hline & Control soil, screening & 5.7 & nd & 0.7 & & \\
\hline & Sawmill 2A & 6.1 & $78 \pm 1$ & $5 \pm 1$ & & 14000 \\
\hline & Sawmill 2B & 6.1 & $78 \pm 1$ & $5 \pm 1$ & & $62000-89000$ \\
\hline & Sawmill 3, enzyme exp. & 6.1 & 66 & 2.6 & & 500 \\
\hline & Control soil, enzyme exp. & 5.5 & nd & nd & & \\
\hline \multicolumn{7}{|l|}{${ }^{\mathrm{a}}$ WHO-TEQ } \\
\hline \multicolumn{7}{|c|}{${ }^{\mathrm{b}}$ Average value of three replicates \pm standard deviation } \\
\hline \multicolumn{7}{|c|}{${ }^{\mathrm{c}} \mathrm{Pb} 700-1200 \mathrm{mg} \mathrm{kg}^{-1}$} \\
\hline \multicolumn{7}{|c|}{${ }^{\mathrm{d}}$ Oil hydrocarbons $2300 \mathrm{mg} \mathrm{kg}^{-1}$ (C5 - C40) } \\
\hline \multicolumn{7}{|c|}{${ }^{\mathrm{e}} \mathrm{nd}=$ not determined } \\
\hline
\end{tabular}

\subsection{Fungal strains}

Fungal strains were obtained from the Fungal Biotechnology Culture Collection (FBCC) of the Department of Food and Environmental Sciences, University of Helsinki. The strains were maintained in the culture collection on malt extract agar $(2 \% \mathrm{w} / \mathrm{v})$. During this work they were kept either on malt extract agar or on potato dextrose agar (PDA, $2.4 \% \mathrm{w} / \mathrm{v}$ ) plates at $+4^{\circ} \mathrm{C}$ and sub-cultured at least every three months.

Four fungal strains were selected for experiments with LME production on solid state cultivation and six fungal strains for bioremediation experiments based on screening experiments and earlier studies (Valentín et al., 2009; Hakala et al., 2004) (Table 4). Most of the fungi belong to WRF, but for bioremediation experiments also two LDF strains and two 
strains from an ecophysiological group between WRF and LDF were selected. All other strains, except G. luteofolius, P. ostreatus and S. rugosoannulata, were isolated from Finland. $G$. luteofolius was isolated from India and $P$. ostreatus and $S$. rugosoannulata obtained from Deutsche Sammlung von Mikroorganismen (DSM).

Table 4. Fungal strains selected based on screening experiments $(\mathrm{WRF}=$ white rot fungi, LDF $=$ litterdecomposing fungi)

\begin{tabular}{|c|c|c|c|c|c|}
\hline Experiment & Fungus & $\begin{array}{l}\mathrm{FBCC}^{\mathrm{a}} \text { number } \\
\text { (old number) }\end{array}$ & $\begin{array}{l}\text { Scientific } \\
\text { order }\end{array}$ & $\begin{array}{l}\text { Ecophysiological } \\
\text { group }\end{array}$ & Article \\
\hline \multirow{4}{*}{$\begin{array}{l}\text { Enzyme } \\
\text { production }\end{array}$} & Cerrena unicolor & 744 (T71) & Polyporales & WRF & I \\
\hline & Pleurotus ostreatus & 375 (DSM11191) & Polyporales & WRF & I \\
\hline & Trametes hirsuta & 507 (K21a) & Polyporales & WRF & 1 \\
\hline & Trametes versicolor & 564 (K120a2) & Polyporales & WRF & 1 \\
\hline \multirow[t]{6}{*}{ Bioremediation } & $\begin{array}{l}\text { Gymnopilus } \\
\text { luteofolius }\end{array}$ & 466 (X9) & Agaricales & $\begin{array}{l}\text { WRF, grows } \\
\text { on stumbs }\end{array}$ & II, III, IV \\
\hline & $\begin{array}{l}\text { Kuehneromyces } \\
\text { mutabilis }\end{array}$ & $508(K 22)$ & Agaricales & $\begin{array}{l}\text { WRF, grows } \\
\text { on stumbs }\end{array}$ & III \\
\hline & $\begin{array}{l}\text { Phanerochaete } \\
\text { velutina }\end{array}$ & 941 (T244) & Polyporales & WRF & II, III, IV \\
\hline & Pleurotus ostreatus & DSM1833 & Polyporales & WRF & \\
\hline & $\begin{array}{l}\text { Sphaerobolus } \\
\text { stellatus }\end{array}$ & 253 (PO203) & Geastrales & LDF & II \\
\hline & $\begin{array}{l}\text { Stropharia } \\
\text { rugosoannulata }\end{array}$ & 475 (DSM11372) & Agaricales & LDF & II, III, IV \\
\hline
\end{tabular}

${ }^{a}$ Fungal Biotechnology Culture Collection (FBCC)

${ }^{\mathrm{b}}$ Not included in FBCC

\subsection{Cultivation methods}

\subsubsection{Liquid inoculum}

Liquid cultivation was always the first step weather the aim was enzyme production in SSC (Article I) or production of fungal inoculum also performed in SSC (Articles II, III, IV). Liquid inoculum was prepared by cutting $2-4(5 \mathrm{~mm} \times 5 \mathrm{~mm})$ agar plugs from the malt extract or the PDA-plates. These were extruded through a syringe to sterile liquid medium consisting of 200 $\mathrm{ml}$ malt extract $(2 \% \mathrm{w} / \mathrm{v})$ in $500 \mathrm{ml}$ Erlenmeyer flasks. Fungi were cultivated for $6-10$ days at $25-28^{\circ} \mathrm{C}$ with continuous shaking (100 - $\left.150 \mathrm{rpm}\right)$. After cultivation, mycelial pellets were homogenized with an Ultra-Turrax (IKA Werke GmbH, Germany) for 10 seconds at $17500 \mathrm{rpm}$ to be used as an inoculum for enzyme production. Otherwise, the liquid inoculum was used as such for cultivating the fungal bark inoculum. 


\section{MnP production in liquid cultivation (Article III)}

Even though enzymes were mainly produced by SSC, one exception was the production of $\mathrm{MnP}$ by liquid cultivation for biodegradation of PCDD/Fs in contaminated soil. The fungus selected for MnP production was K. mutabilis because it was known to secrete the enzyme efficiently. MnP was produced by liquid cultivation in 14 days and the cultivation medium was concentrated approximately ten-fold by ultrafiltration. The detailed description of the MnP production can be found in Article III, Chapter 2.2.

\subsubsection{Solid-state cultivations (SSC)}

\section{Substrates for SSC (Article I)}

Oat husks, fibre sludge and combined fibre and de-inking sludge (FDS) were used as substrates in SSC for enzyme production. Oat husks were obtained from a flour mill (Rapion Tuote Inc., Finland) and the other waste materials from a paper pulp mill (UPM Kymmene, Kaipola, Finland). Properties of these materials are presented in Table 5. The amount of $\mathrm{N}$ and $\mathrm{P}$ describes the nutritional value of these materials and the amount of $\mathrm{Mn}$ and $\mathrm{Cu}$ trace elements that induce the production of lignin modifying enzymes.

Table 5. Properties of industrial waste materials used as substrates in SSC

\begin{tabular}{lcccccc}
\hline Material & Dry matter $(\%)$ & $\mathbf{p H}$ & $\mathbf{N}(\% \mathrm{dm})$ & $\mathbf{P}(\% \mathrm{dm})$ & $\mathbf{M n}\left(\mathbf{\mu g ~ g}^{-1}\right)$ & $\mathbf{C u}\left(\boldsymbol{\mu g ~ g}^{-1}\right)$ \\
\hline Oat husks & 92 & 6.1 & 1.36 & 0.04 & 19 & 6 \\
Fibre sludge & 57 & 7.4 & 0.16 & 0.13 & 43 & 9 \\
FDS $^{\mathrm{a}}$ & 49 & 7.1 & 0.51 & 0.07 & 278 & 156 \\
\hline
\end{tabular}

${ }^{\mathrm{a}}$ Fibre and de-inking sludge

\section{LME production in SSC (Article I)}

The fungi selected for enzyme production experiments (Table 4) were cultivated in parallel plastic jars in $100 \mathrm{~g}$ scale. The cultivation medium contained oat husks supplemented with FDS at $0 \%, 20 \%$ and $50 \%$ concentrations (fibre sludge was included only to the screening experiments). Water was added so that the dry matter content of the medium was $33 \%$. Each jar was inoculated with $3 \mathrm{ml}$ of homogenized inoculum. The jars were incubated for 3 to 14 days at $28^{\circ} \mathrm{C}$ and aerated continuously with moisturized air (0.1 I $\mathrm{min}^{-1} / \mathrm{jar}$ ). One jar represented one sample. A smaller $15 \mathrm{~g}$ scale without aeration was used in the screening studies (Table 7). 


\subsubsection{Cultivation of fungal bark inoculum}

\section{Inoculum for the laboratory experiments}

The fungi selected for bioremediation experiments (Table 4, except $K$. mutabilis and $P$. ostreatus) were cultivated on bark in high density polyethene (HDPE) plastic bags (Suominen Oy, Kauhava, Finland). Bark was first soaked in water overnight and then drained. Wet bark, 1 $\mathrm{kg}$ in each plastic bag, was autoclaved $\left(30 \mathrm{~min}, 121^{\circ} \mathrm{C}\right)$ and the cooled bark was inoculated with $200 \mathrm{ml}$ of liquid inoculum. The bags were incubated at room temperature $\left(21^{\circ} \mathrm{C}\right)$ and aerated continuously with sterile moisturized air $\left(1 \mid \mathrm{min}^{-1}\right)$. The incubation time varied from three to five weeks until the surface of the bark was fully covered with fungal mycelium. The average dry matter content of the "ready to use" bark inoculum was $30 \%$ (analysed). A value from literature (95\%) was used as the average organic matter content for pine bark (Alén, 2011).

For the determination of the enzyme activity of the fungal inoculum, cultivations were performed in small plastic jars (100 g of wet bark in each plastic jar) in similar conditions as in the $1 \mathrm{~kg}$ scale. Liquid inoculum $(20 \mathrm{ml}$ ) was homogenized at $17500 \mathrm{rpm}$ for $10 \mathrm{~s}$ (Ultra-Turrax T25, IKA-Werke, Germany) and mixed with $100 \mathrm{~g}$ of wet bark. One jar represented one sample. Nine samples with three replicates (altogether 27 samples per fungus) were taken for enzyme activity measurements, from 14 to 42 days after inoculation, with 3 to 4 days interval.

\section{Inoculum for the field scale experiments}

Production of fungal inoculum on bark was scaled up for the field experiment (Article IV). The solution was a tray bioreactor type cultivation cabin where the humidity was maintained by aeration with moisturized air (Figure $\mathbf{8 A}$ ). Two cabinets were built from stainless steel sheets and 12 plastic dishwasher baskets (length $50 \mathrm{~cm}$, width $50 \mathrm{~cm}$, height $10 \mathrm{~cm}$ ) were placed inside each cabinet as shelves. The capacity of one basket was $3.5 \mathrm{~kg}$ of wet bark, thus the total capacity of two cabinets was $84 \mathrm{~kg}$.

Before inoculation, moist pine bark was surface sterilized with steam, which was conducted into the cultivation cabinet from the bottom and led through the baskets. The temperature of the cabinet was kept over $90^{\circ} \mathrm{C}$ for one hour, the cabinet was then allowed to cool overnight, and steaming was repeated the next day. This type of heat treatment is called tyndallisation. The first steaming kills vegetative cells, but not necessarily spores. On the second day the spores that survived the first steaming, germinate into vegetative cells. These cells are then killed by the second steaming.

The bark $(3.5 \mathrm{~kg})$ in each cultivation basket was inoculated with $400 \mathrm{ml}$ of liquid inoculum $(P$. velutina, which had been selected based on laboratory experiments) and the fungus was cultivated for 5 weeks at room temperature $\left(21^{\circ} \mathrm{C}\right)$. Non-sterile moist air was conducted into the cultivation cabinet $\left(301 \mathrm{~min}^{-1}\right)$. At the end of the cultivation, the surface of the bark was fully covered with fungal mycelium (Figure 8B). 
A

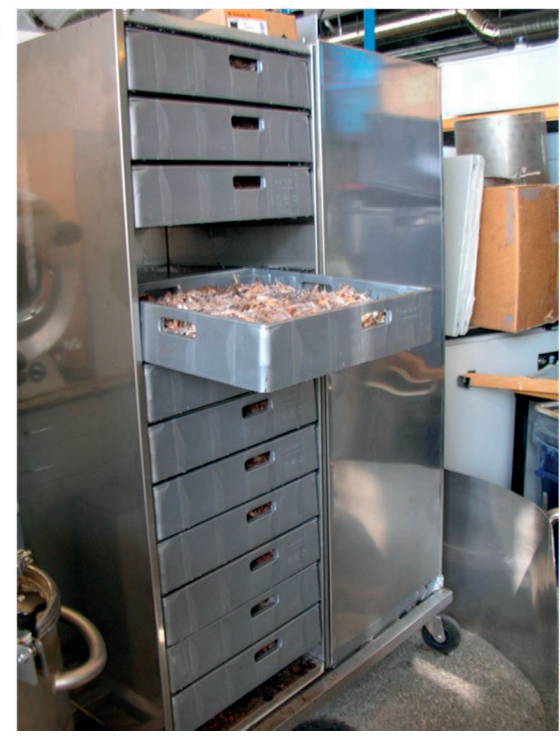

B

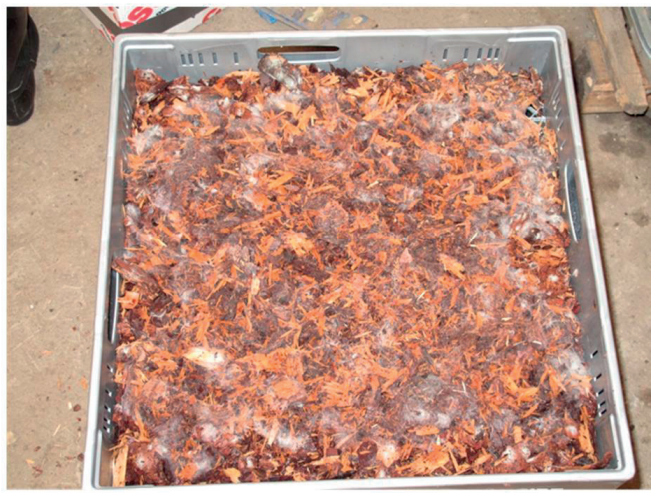

Figure 8. A) Cultivation cabin for the production of fungal bark inoculum for the field scale experiments. B) $P$. velutina growing on pine bark after 5 weeks of cultivation.

For the first field experiment the fungal bark inoculum (Pleurotus ostreatus DSM1833) was obtained from Mzymes Oy. It was similarly grown on pine bark as in our own production process for the second field experiment, but it was packed in tubes made from biodegradable plastic net.

\subsection{Biodegradation experiments}

\subsubsection{Laboratory scale soil experiments}

\section{Screening of fungal strains}

Both PAH-contaminated and PCDD/F-contaminated soils, and in addition not contaminated soils, were used for screening of suitable fungal strains for biodegradation experiments. Six different soils were used: 1) Oil-contaminated soil, 2) PAH-contaminated soil, 3) diluted PAHcontaminated soil $(1: 1), 4)$ composted green waste, 5) PCDD/F-contaminated soil (Sawmill 1), and 6) not contaminated control soil (Table 3). Composted green waste was used to dilute the PAH-contaminated soil and thus it was tested also separately as an extra control. A Petri-dish was filled with non-sterile soil, moistened if needed, and $2.5 \mathrm{~g}$ of pine bark with fungal mycelium was placed on top of the soil. Fungal growth was examined visually during 30 days of incubation at room temperature in dark. Moisture content of the soil was kept constant by adding water when needed. 


\section{Soil experiments in aerated bottles}

Two-litre glass bottles were filled with a layer of expanded clay $(150 \mathrm{~g})$ at the bottom, followed by layers of moist soil ( $350 \mathrm{~g}-400 \mathrm{~g})$, fungal inoculum growing on bark $(100 \mathrm{~g})$, and a top layer of moist soil ( $350 \mathrm{~g}-400 \mathrm{~g}$ ) (Figure 9A). All bottles were aerated with moist air $\left(0.51 \mathrm{~min}^{-1}\right)$. The inlet air tube was placed to the expanded clay layer at the bottom, so that air would be spread evenly and move up through all layers (Article II, Figure 1).

A

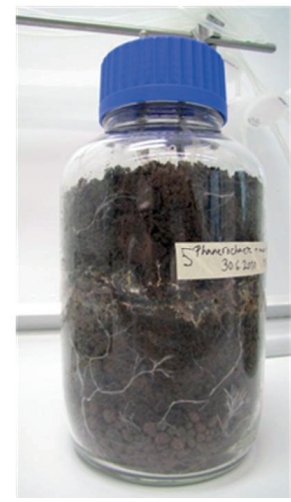

B

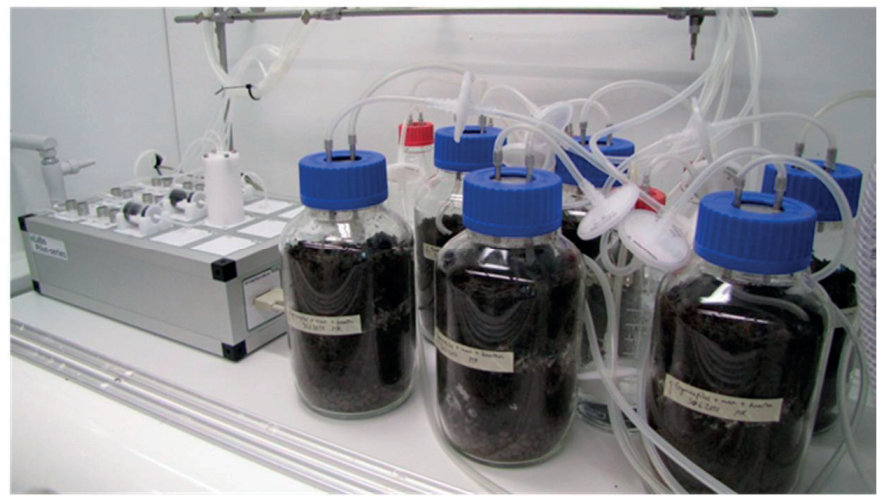

Figure 9. Experimental set-up in the laboratory experiments, A) growth of $P$. velutina 2 months after inoculation in the oil-contaminated soil, B) soil bottles connected to the $\mathrm{CO}_{2}$ analyser (eLabs Oy Engineering, Finland).

\section{Degradation of SOM by fungi}

The bottles were filled with soil rich in organic matter (700 g per one bottle) (Table 3) and fungal bark inoculum (100 g). In control bottles, gravel (Maxit crushed stone for sanding, grain size 3 - $6 \mathrm{~mm}$, Optiroc Oy Ab, Finland) was used instead of soil (equal volume) to be able to estimate $\mathrm{CO}_{2}$ production from fungal bark inoculum. $\mathrm{CO}_{2}$ production during the experiment was calculated by subtracting inlet air $\mathrm{CO}_{2}$ concentration from exhaust $\mathrm{CO}_{2}$ concentration, and after that calculating the cumulative $\mathrm{CO}_{2}$ production, when the aeration rate was kept constant.

$\mathrm{CO}_{2}$ coming from SOM was calculated by subtracting the amount of $\mathrm{CO}_{2}$ of gravel bottles $\left(\mathrm{CO}_{2}\right.$ coming from fungal bark inoculum) from that of soil bottles $\left(\mathrm{CO}_{2}\right.$ coming from soil and fungal bark inoculum) (Equation 1):

$\mathrm{CO}_{2} \operatorname{prod}$ from SOM $(g)=A v$ soil $\mathrm{CO}_{2} \operatorname{prod}(g)-A v \operatorname{bark} \mathrm{CO}_{2} \operatorname{prod}(g)$

Estimated $\mathrm{CO}_{2}$ production from SOM in 3 months was calculated by dividing the $\mathrm{CO}_{2}$ production by the duration of the experiment and multiplying by 90 (Equation 2):

Est $\mathrm{CO}_{2}$ prod in 3 months $(g)=\mathrm{CO}_{2}$ prod from SOM $(g) / t(d) * 90 d$ 
Estimated carbon loss from soil was calculated by comparing the $\mathrm{CO}_{2}$ production from SOM to the theoretical maximum $\mathrm{CO}_{2}$ production from soil (Equation 3 ) which was calculated based on the analysed carbon content (Equation 4):

Est carbon loss from soil $(\%)=\mathrm{CO}_{2}$ prod $(\mathrm{g}) /$ Theor $\max \mathrm{CO}_{2}$ prod from soil $(\mathrm{g}) * 100$

Theor max $\mathrm{CO}_{2}$ prod from soil $(\mathrm{g})=m($ dry soil $) *(c($ carbon $) / 12 \mathrm{~g} / \mathrm{mol}) * 44 \mathrm{~g} / \mathrm{mol}$

In this experiment, $\mathrm{CO}_{2}$ was analyzed on-line from the exhaust air by mass spectrometer (OmniStar GSD 301, Pfeiffer Vacuum GmbH, Germany). Due to the limited amount of air channels in the mass spectrometer only two replicate bottles were used.

\section{Degradation of PAHs and PCDD/Fs by fungi}

The bottles were filled with either PAH-contaminated soil mixed with composted green waste (1:1) or PCDD/F contaminated soil (Sawmill 2B, 800 g per one bottle) (Table 3). The soil was sieved through $5 \mathrm{~mm}$ mesh prior to use for laboratory experiments. Control bottles contained only expanded clay $(150 \mathrm{~g})$ and soil $(800 \mathrm{~g})$ without fungal inoculum. All the incubations were performed at room temperature with three replicate bottles, except only two replicates for control. Carbon dioxide $\left(\mathrm{CO}_{2}\right)$ was measured on-line from the exhaust air by $\mathrm{CO}_{2}$ analyser (custom made instrument based on IR absorbance measurement, eLabs Oy Engineering, Finland) (Figure $9 \mathrm{~B}$ ). $\mathrm{CO}_{2}$ production during the experiment was calculated by subtracting inlet air $\mathrm{CO}_{2}$ concentration from exhaust $\mathrm{CO}_{2}$ concentration, and after that calculating the cumulative $\mathrm{CO}_{2}$ production, when the aeration rate was kept constant. Due to variation in organic matter content in the bottles, $\mathrm{CO}_{2}$ production is presented in relation to a mass unit of organic matter.

Two degradation experiments were performed with PCDD/F-contaminated soil. When $\mathrm{CO}_{2}$ was measured, no samples were taken during the experiment as described previously. However, when the LME activity in the soil was measured, it was necessary to take samples during the incubation. Therefore also the experimental set-up was planned differently and the fungal bark inoculum in a perforated plastic tube was placed vertically in a glass bottle $(500 \mathrm{ml})$. First vermiculite $(100 \mathrm{~g})$ was placed at the bottom of the bottle followed by a plastic net to minimize mixing of vermiculite with soil. Next a perforated plastic tube containing fungal bark inoculum (10 g) was placed in the middle of the bottle, and finally the tube was surrounded with non-sterile moist soil (Sawmill 2A, $350 \mathrm{~g}$ ). An in-let air tube was placed to the vermiculite layer at the bottom. The bottles were properly sealed and continuously aerated with moist air. All the incubations were performed at room temperature with two replicate bottles from which soil samples were taken for enzyme activity measurements at 14 days intervals.

\section{Degradation of PCDD/Fs by fungal enzymes}

PCDD/F -contaminated soil (Sawmill 3, Table 3) was air-dried and sieved through $2 \mathrm{~mm}$ mesh prior to use in degradation experiments. Glass bottles $(150 \mathrm{ml})$ were filled with $25 \mathrm{~g}(\mathrm{dm})$ of 
non-sterile PCDD/F -contaminated soil. Alternatively, the same amount of sandy soil was used as a control.

Concentrated crude enzyme (Article III, Chapter 2.2) and $\mathrm{H}_{2} \mathrm{O}_{2}$-solution were added to the soil ( $250 \mu \mathrm{l}$ of enzyme liquid $+25 \mu \mathrm{l}$ of $\mathrm{H}_{2} \mathrm{O}_{2}$-solution per $\mathrm{g} \mathrm{dm}$ of soil). The concentrated crude enzyme contained mainly $\mathrm{MnP}$ activity (4000 $\mathrm{U} \mathrm{I}^{-1}$, laccase activity insignificant). The soil environment contains sufficient amount of $\mathrm{Mn}^{2+}$-ions, which are needed when $\mathrm{MnP}$ catalyze the oxidation of $\mathrm{Mn}^{2+}$ to $\mathrm{Mn}^{3+}$. Additionally $\mathrm{H}_{2} \mathrm{O}_{2}$ is required as an electron acceptor. Concentrations of up to $10 \mathrm{mmol} \mathrm{I}^{-1}$ in $\mathrm{H}_{2} \mathrm{O}_{2}$-solution were tested and the maximum activity was obtained at $8 \mathrm{mmol}^{-1}$ (results not shown).

Soil was incubated at room temperature for 10 days. Samples for enzyme activity measurements were taken from the bottles on a daily basis. MnP activity was measured with the filter centrifugation method (Heinonsalo et al., 2012). There were three parallel bottles filled with contaminated soil and two parallel bottles filled with control soil.

\subsubsection{Pilot-scale experiment for degradation of SOM}

A box with a volume of $0.56 \mathrm{~m}^{3}$ was filled with soil $(299 \mathrm{~kg}$ ) and six perforated tubes (Figure 10A) containing fungal bark inoculum ( $1.5 \mathrm{~kg}$ in each tube, total weight $9.0 \mathrm{~kg}$ ) (Article II, Figure 3). During the experiment, soil was aerated with moist air $\left(301 \mathrm{~min}^{-1}\right)$ from the bottom of the box. The box was covered with a tarpaulin to prevent drying of the soil. Mycelial growth of the fungus could be followed through a Plexi-glass wall (Figure 10B). The box was placed on top of

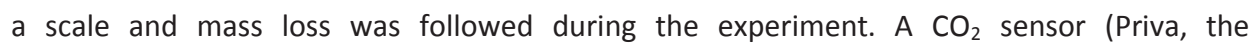
Netherlands) was placed above the soil surface and $\mathrm{CO}_{2}$ production was monitored. After 3 and 6 months samples were taken and dry matter analysed.

A

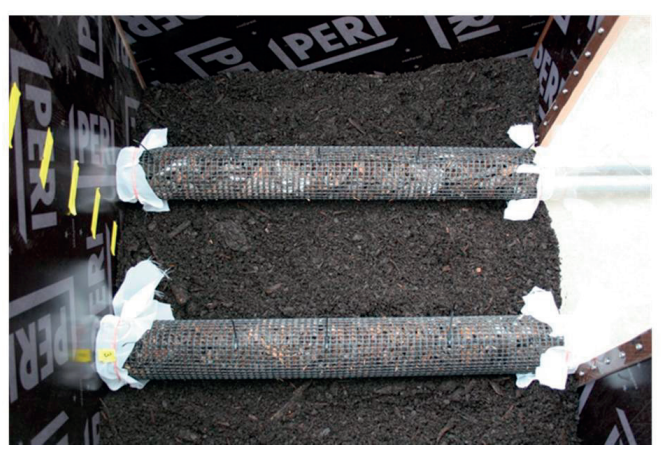

B

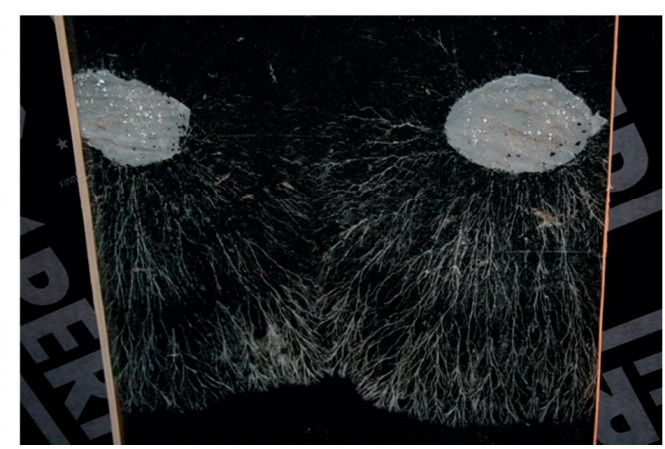

Figure 10. Experimental set-up in the pilot-scale experiment. A) Fungal inoculum was placed inside the soil in perforated tubes. B) Mycelial growth was followed through a Plexi-glass wall. 


\subsubsection{Field-scale experiment for degradation of PAHs}

Two successive field experiments were carried out. In the first field experiment original, not diluted PAH-soil (Table 3) was used, and in the second field experiment the same PAH-soil was diluted with composted green waste (1:1) (Table 6). In the first field experiment, moist pine bark ( $4 \% \mathrm{w} / \mathrm{w}$ ) was added to the PAH-contaminated soil (starting concentration $5300 \mathrm{mg} \mathrm{kg}$ ${ }^{1}$ ). Altogether $3700 \mathrm{~kg}$ of soil (and $140 \mathrm{~kg}$ of bark) was divided into two piles. The fungal inoculum was packed in tubes, made from biodegradable plastic net, which were added to one pile in two layers (Figure 11A). The other pile was control pile and it was left without inoculum.

Table 6: Amounts of PAH-contaminated soil and amendments in the first and the second field experiment

\begin{tabular}{lcc}
\hline & $\begin{array}{c}\mathbf{1}^{\text {st }} \text { Field experiment } \\
\text { Original PAH-soil with } \\
\text { some added bark }(4 \% \mathrm{w} / \mathrm{w})\end{array}$ & $\begin{array}{c}\mathbf{2}^{\text {nd }} \text { Field experiment } \\
\text { PAH-soil diluted with } \\
\text { composted green waste }(1: 1)\end{array}$ \\
\hline Soil (kg) & 3700 & 2000 \\
Bark (kg) & 140 & - \\
Composted green waste $(\mathbf{k g})$ & - & 2000 \\
Total weight (kg) & 3840 & 4000 \\
Fungal inoculum & tubes & cakes \\
Upper layer & $4 \times 8 \mathrm{~kg}$ & $8 \times 3.5 \mathrm{~kg}$ \\
Lower layer & $6 \times 8 \mathrm{~kg}$ & $12 \times 3.5 \mathrm{~kg}$ \\
Total weight (kg) & 80 & 70 \\
Aeration (I min $^{-1}$ per pile) & 35 & 70 \\
\hline
\end{tabular}

The experimental set-up in the second field experiment was almost identical to the first field experiment, except that the fungal bark inoculum was not packed in tubes but was added to the soil as cakes (Figure 11B). In the second field experiment, PAH-contaminated soil was mixed with composted green waste (1:1, on wet mass basis, starting concentration $1400 \mathrm{mg}$ $\left.\mathrm{kg}^{-1}\right)$. Altogether $4000 \mathrm{~kg}$ of soil-compost mixture was divided into two piles. The fungal inoculum was added to one pile in two layers and the other pile, which was a control pile, was left without inoculum. All piles in both experiments were aerated with moist air ( $35-701 \mathrm{~min}^{-1}$ per pile) and covered with a tarpaulin to avoid drying of the soil. During incubation, data loggers registered temperature eight times a day inside and outside the piles. The field scale experiments were carried out at a commercial soil treatment facility $\left(1^{\text {st }}:\right.$ Soilrem Oy, Lohja, Finland, and $2^{\text {nd }}$ : Soraset Oy, Forssa, Finland) in a non-heated hall with a concrete floor.

Two parallel composite soil samples were taken with an Edelman auger (Eijkelkamp Agrisearch Equipment BV, the Netherlands) once a month from both piles (fungal treatment pile \& control pile). One composite sample consisted of four sub-samples taken at $0.3 \mathrm{~m}$ depth. The subsamples were mixed together and sieved through $8 \mathrm{~mm}$ mesh. Samples were analysed for dry matter, organic matter, $\mathrm{pH}$ and $\mathrm{PAH}$ concentration. In addition, the growth of $P$. velutina as ITS region DNA copy number ( $2^{\text {nd }}$ exp.), the total amount of indigenous bacteria, and the PAH 
degradation potential by gram-positive and gram-negative bacteria were determined. The first and last samples were run for ecotoxicological tests.

\section{Cross-section of the fungal treatment pile:}

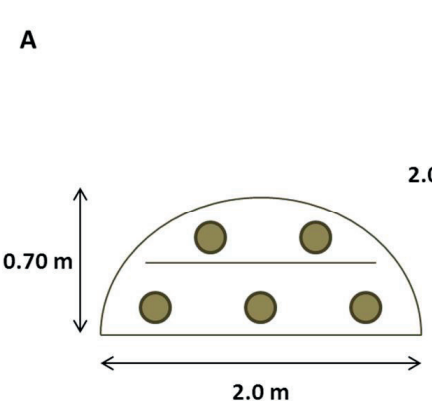

B

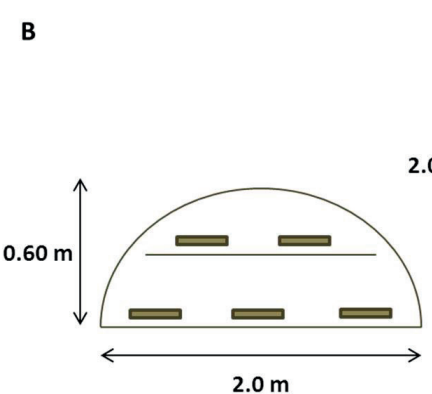

\section{The lower layer with fungal inoculum:}
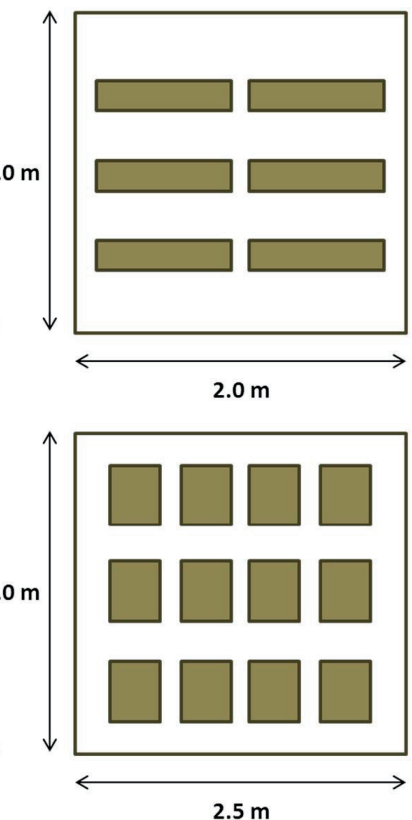

The upper layer with fungal inoculum:
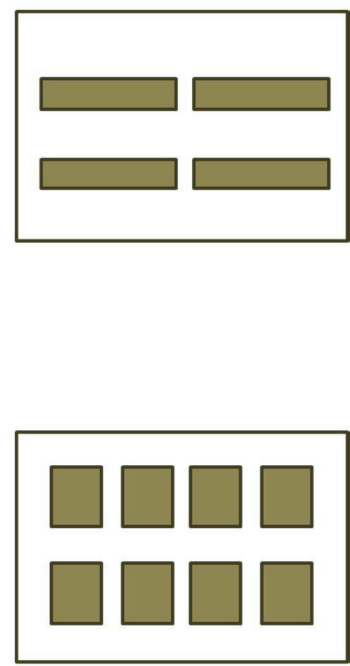

Figure 11. Experimental set-up in the field experiments, A) first experiment with fungal inoculum tubes, B) second experiment with fungal inoculum cakes.

\subsection{Analysis methods}

\subsubsection{Soil analysis}

\section{Dry matter, organic matter and $\mathrm{pH}$}

Dry matter of the soil was determined by drying the fresh soil at $105^{\circ} \mathrm{C}$ overnight $(16 \mathrm{~h})$. Organic matter of the soil was determined as loss on ignition (mass $\%$ of $\mathrm{dm}$ ) at $440^{\circ} \mathrm{C}$ for 5 hours (Article II) or at $550^{\circ} \mathrm{C}$ for four hours (Articles III \& IV). Soil pH was measured in $0.01 \mathrm{~mol}$ $\mathrm{I}^{-1} \mathrm{CaCl}_{2}$ solution with a suspension ratio 1:2.5 (w/v) (Article II) or in $1 \mathrm{~mol} \mathrm{I}^{-1} \mathrm{KCl}$ solution with the same suspension ratio (Articles III \& IV). 


\section{PAH concentration}

PAH concentration was measured as a sum of $16 \mathrm{PAH}$ compounds (listed by the United States Environmental Protection Agency), namely: naphthalene, acenaphtylene, acenaphthene, fluorene, phenanthrene, anthracene, fluoranthene, pyrene, benzo(a)anthracene, chrysene, benzo(b)fluoranthene, benzo(k)fluoranthene, benzo(a)pyrene, indeno(1,2,3-cd)pyrene, dibenzo(a,h)anthracene and benzo(g,h,i)perylene (Article IV, Chapter 2.1). For quantitative PAH determination, the soil samples were extracted with acetone using ultrasonic method (US EPA method $3550 \mathrm{C}$ ). The extracts were then analyzed using gas chromatography-mass spectrometry (GC-MS) following the standard ISO 18287:2006 (SGS Inspection Services Oy, Finland).

\section{Heavy metals}

In addition to PAHs, heavy metals ( $\mathrm{As}, \mathrm{Cd}, \mathrm{Cr}, \mathrm{Cu}, \mathrm{Ni}, \mathrm{Pb}, \mathrm{Zn}, \mathrm{Hg}$ ) were analysed from the PAHcontaminated soil (SGS Inspection Services Oy, Finland). The concentration of arsenic (28 $\mathrm{mg}$ $\mathrm{kg}^{-1}$ ) was slightly higher than median of natural concentrations $\left(0.1-25 \mathrm{mg} \mathrm{kg}^{-1}\right)$ in Finnish soils (Valtioneuvoston asetus 214/2007), but the concentrations of the other heavy metals were at naturally occurring levels (results not shown).

\section{Bioaccessibility of PAH compounds}

The bioaccessible fraction of PAHs in contaminated soil was predicted by using supercritical fluid extraction (SFE) with $\mathrm{CO}_{2}$ at $50^{\circ} \mathrm{C}$ and 200 bar. This was then compared with the total concentration (100 \%) of each $\mathrm{PAH}$, which was determined with exhaustive analytical accelerated solvent extraction (Čvančarová et al., 2013). The detailed description of the PAH bioaccessibility analysis can be found in Article IV, Chapter 2.2.

\section{$\mathrm{PCDD} / \mathrm{F}$ concentration}

All 17 toxic PCDD/F-congeners (those with chlorine groups in the 2,3,7,8 positions) were analysed from soil samples by isotope dilution, high resolution capillary column gas chromatography (HRGC) / high resolution mass spectrometry (HRMS) (EPA method 1613) by SGS IAC laboratory, Antwerpen, Belgium. The total PCDD/F concentration in soil is given in Table 3 as toxic equivalent (WHO-TEQ), which was calculated by adding up all the 2,3,7,8-TCDD equivalents (WHO 2005 TEF) of all the individual congeners.

\subsubsection{Enzyme activity analysis}

Enzyme activities from solid-state and bark inoculum cultivations were analyzed from extracted samples. $\mathrm{MnP}$ activity was measured by monitoring the formation of $\mathrm{Mn}^{3+}$-malonate 
complexes at $270 \mathrm{~nm}$ (Wariishi et al., 1992), and laccase activity by the oxidation of ABTS at $436 \mathrm{~nm}$ (Niku-Paavola et al., 1988). The enzyme activities were expressed as $\mathrm{mU} \mathrm{g}^{-1} \mathrm{dm}$ of the sample. The detailed description of the enzyme activity analysis from solid-state and bark inoculum cultivations can be found in Article I, Chapter 2.4 and Article IV, Chapter 2.4.3 respectively.

In the pilot-scale experiment, in addition to $\mathrm{MnP}$ and laccase, also endo-1,4- $\beta$-glucanase, endo$1,4-\beta$-xylanase and endo-1,4- $\beta$-mannanase activities were determined from the fungal bark inoculum. Also these enzyme activities were expressed as $\mathrm{mU} \mathrm{g}^{-1} \mathrm{dm}$ of the sample. The detailed description of the enzyme activity analysis used in the pilot-scale experiment can be found in Article II.

Two methods (filter centrifugation and buffer extraction) were applied to monitor the activity of fungal enzymes in soil matrix. The detailed description of both methods can be found in Article III, Chapter 2.4. MnP activity was measured by monitoring the formation of $\mathrm{Mn}^{3+}$ malonate complexes (Wariishi et al., 1992), and laccase activity by the oxidation of ABTS (NikuPaavola et al., 1988; Eggert et al., 1996). The enzyme activities were expressed as $\mathrm{mU} \mathrm{g}^{-1} \mathrm{dm}$ of the sample.

\subsubsection{Microbiological analysis}

The total amount of indigenous bacteria, the PAH degradation potential by gram-positive and gram-negative bacteria, and the growth of $P$. velutina as ITS region DNA copy number were determined from the PAH-contaminated soil during the field experiment. The total amount of indigenous bacteria was estimated by analysing the number of 16S rDNA genes in the soil sample. All prokaryotic cells contain on average four copies of this gene. The PAH degradation potential by gram-positive and gram-negative bacteria was estimated by analysing the amount of ring hydroxylating dioxygenase (RHD) genes of both bacterial classes (Cebron et al., 2008). The growth of $P$. velutina was also evaluated by a DNA quantification method using specific primers designed for the ITS region of this fungus (Šnajdr et al., 2011). Since there are usually more than one ITS region in a fungal cell, the cell number of $P$. velutina is not directly comparable with the amount of ITS regions in a sample. However, comparisons can be made how the $P$. velutina ITS region DNA copy number is changing over time. The detailed description of the microbiological analysis can be found in Article IV, Chapter 2.6.

\subsubsection{Ecotoxicological tests}

The toxicity of the PAH-soil, before and after the field experiment, was determined by survival and reproduction of earthworms (Eisenia fetida) and inhibition of seed germination (garden cress, Lepidium sativum, and red clover, Trifolium pratense). The detailed description of the ecotoxicological tests can be found in Article IV, Chapter 2.7. 


\section{Results and discussion}

\subsection{Production of LMEs in SSC (Article I)}

The capability of 15 ligninolytic fungi to grow on selected industrial waste materials was screened (Table 7). Also the ability of some fungi to produce laccase on combined fibre and de-inking sludge (FDS) was tested. Based on the screening studies, strains that grew well on oat husks, but were also able to grow and produce laccase on FDS, were selected for further experiments. The strains were: Pleurotus ostreatus FBCC375, Trametes versicolor FBCC564, Trametes hirsuta FBCC507 and Cerrena unicolor FBCC744.

Table 7. Fungal growth on three industrial waste materials, screening experiments

\begin{tabular}{|c|c|c|c|c|c|}
\hline Strain & $\begin{array}{l}\text { FBCC number } \\
\text { (old number) }\end{array}$ & $\begin{array}{c}\text { Oat } \\
\text { husks }\end{array}$ & $\begin{array}{l}\text { Fibre } \\
\text { sludge }\end{array}$ & FDS $^{a}$ & $\begin{array}{c}\text { Laccase } \\
\text { production } \\
\text { on FDS }\end{array}$ \\
\hline Bjerkandera adusta & 856 (T185i) & + & nd & + & nd \\
\hline Bjerkandera sp. & 395 (BOS55) & nd & nd & + & nd \\
\hline Ceriporiopsis subvermispora & $314(C Z-3)$ & + & nd & - & nd \\
\hline Cerrena unicolor & $744(\mathrm{T71})$ & + & nd & + & + \\
\hline Cerrena unicolor & $115(316)$ & + & nd & + & nd \\
\hline Irpex lacteus & 384 (CBB-196) & nd & + & + & nd \\
\hline Irpex lacteus Fr. 238 & $1012(617 / 93)$ & + & nd & + & - \\
\hline Merulius tremellosus & 227 (PO171i) & + & - & - & nd \\
\hline Phanerochaete chrysosporium & 398 (ATCC20696) & nd & nd & + & - \\
\hline Phlebia radiata & 43 (ATCC64658) & + & $?$ & + & - \\
\hline Pleurotus ostreatus & 375 (DSM11191) & + & + & + & + \\
\hline Stropharia rugosoannulata & 475 (DSM11372) & + & - & - & nd \\
\hline Trametes hirsuta & 507 (K21a) & + & nd & + & + \\
\hline Trametes versicolor & 564 (K120a2) & + & nd & + & + \\
\hline Trametes versicolor & $457(\mu 1)$ & + & nd & + & nd \\
\hline
\end{tabular}

\section{Evaluation:}

- =no growth / no enzyme activity

$+=$ visible growth / enzyme activity

nd $=$ not determined

${ }^{\mathrm{a}}$ FDS = fibre and de-inking sludge

Three industrial waste materials were tested as substrates for production of LMEs in SSC. These three materials were oat husks and waste from paper process industry: fibre sludge and combined fibre and de-inking sludge (FDS). However, fibre sludge was found to be the poorest substrate in the screening experiments and it was left out from the further studies. Because fibre sludge contains a lot of filling material, such as kaolin, it formed a dense cake and fungi were only able to grow on surface of it. Similar to fibre sludge, also FDS, when used as a sole substrate, did not give good growth. The structure of FDS medium was airy, but FDS contains toxic heavy metals, such as $\mathrm{Ba}, \mathrm{Cr}, \mathrm{Cu}, \mathrm{Mn}, \mathrm{Sn}, \mathrm{Ti}$ and $\mathrm{Zn}$ (Tucker et al., 2000), which inhibit the 
growth. Oat husks seemed to be the most promising waste material, and thus it was used as a substrate in further studies as such or with combinations of FDS (20\% or $50 \%)$.

Oat husks give an airy structure to the cultivation medium. They contain more nutrients than the other waste materials as well as plant cell wall lignocellulose (2 - $10 \%$ ) (Welch et al., 1983), which acts as an inducer for LME production. The effect of FDS addition to oat husks was believed to increase the laccase and maybe also the MnP production, because FDS contains copper and manganese (Table 5). Copper induces laccase synthesis (e.g. Palmieri et al., 2000; Galhaup and Haltrich, 2001) and it also serves as the cofactor in the catalytic centre of laccase. Manganese regulates the expression of $\mathrm{MnP}$ and it also participates in the reaction cycle of $\mathrm{MnP}$ (Brown et al., 1990). However, both copper and manganese are toxic when present in excess. Growth of Phanerochaete chrysosporium in liquid media was inhibited in the presence of 150 ppm Cu or 300 ppm Mn (Baldrian, 2003).

The maximum enzyme activities in SSC on that media which gave the highest MnP activities are presented in Table 8. The highest MnP activity $\left(1060 \mathrm{U} \mathrm{g}^{-1}\right)$ was obtained with $T$. versicolor on the oat husks medium. The highest laccase activity $\left(2970 \mathrm{U} \mathrm{g}^{-1}\right)$ was obtained with $C$. unicolor on the medium containing $50 \%$ oat husks and $50 \%$ FDS (Article I: Figure 4). Nearly as high laccase activities $\left(2600 \mathrm{U} \mathrm{g}^{-1}\right)$ were obtained with the medium containing $80 \%$ oat husks and $20 \%$ FDS, which gave the highest $\mathrm{MnP}$ activities $\left(850 \mathrm{U} \mathrm{g}^{-1}\right.$ ) with C. unicolor. Generally, FDS addition to oat husks medium had a positive effect on laccase production, but not so much on $\mathrm{MnP}$ production. Only C. unicolor and $P$. ostreatus produced more $\mathrm{MnP}$ on the medium containing $20 \%$ FDS compared to the medium without any FDS addition (Article I: Figure 2).

Table 8. Media giving the maximum enzyme activity with different fungi in SSC (Article I: Table II)

\begin{tabular}{llll}
\hline Fungus & Substrate & $\mathbf{M n P}\left(\mathbf{U ~ g ~ g}^{-1}\right)^{\mathbf{a}, \mathbf{b}}$ & Laccase $\left(\mathbf{U ~ g}^{-1}\right)^{\mathbf{a}, \mathbf{b}}$ \\
\hline Cerrena unicolor & Oat husks + 20\% FDS & $850 \pm 110\left(5 \mathrm{~d}^{\mathrm{d}}\right)$ & $2600 \pm 270(14 \mathrm{~d})$ \\
Pleurotus ostreatus & Oat husks + 20\% FDS & $650 \pm 290(12 \mathrm{~d})$ & $1010 \pm 690(7 \mathrm{~d})$ \\
Trametes hirsuta & Oat husks & $870 \pm 390(5 \mathrm{~d})$ & $670 \pm 410(5 \mathrm{~d})$ \\
Trametes versicolor & Oat husks & $1060 \pm 40(5 \mathrm{~d})$ & $590 \pm 120(5 \mathrm{~d})$ \\
\hline
\end{tabular}

${ }^{a}$ Calculated per $g$ dry mass of the cultivation medium

${ }^{b}$ Average values of two replicates \pm the range of variation

${ }^{c}$ Fibre and de-inking sludge

${ }^{\mathrm{d}}$ cultivation time in parenthesis

Since $C$. unicolor clearly gave the highest laccase activities, but was also able to produce a good $\mathrm{MnP}$ activity in short time ( $5 \mathrm{~d}$ ), it was selected for later pilot-scale studies in a solid-state bioreactor (Moilanen et al., 2014; Mattila et al., 2008). Our MnP results in the small laboratory scale were on the same level than the highest MnP activity results found in the literature (Article I: Table 2). With laccase activities there is more variation in the results found in the literature but our results represent the average level. As a result, we were able to produce considerable amounts of LMEs on a low cost medium. These enzymes could be used e.g. in bioremediation applications, such as purifying waste waters from textile industry and bleach 
plant effluents (Rodríguez Couto et al., 2005; Moilanen et al., 2010; Wu et al., 2005) or treatment of contaminated soil (Article III, Rao et al., 2010).

\subsection{LME activities in fungal bark inoculum and in PCDD/F-soil (Articles II, III and IV)}

LMEs, MnP and laccase, were measured with the extraction method both from the bark and the PCDD/F-contaminated soil being treated with selected fungi (Sawmill 2A, Table 3). The total duration of incubation period was on bark $42 \mathrm{~d}$ for all fungi, in soil for $S$. rugosoannulata and G. luteofolius $70 \mathrm{~d}$, and in soil for $P$. velutina $77 \mathrm{~d}$. The highest MnP activity was obtained with $P$. velutina both from the bark and from the contaminated soil (Table 9). This was not surprising since high $\mathrm{MnP}$ activities with this fungus had been measured previously from bark cultivation (Valentín et al., 2009). On the contrary, the laccase activities with all the three fungi were very low. However, enzyme activities analysed from bark or soil may underestimate the total enzyme activity in situ. In this study, the enzyme activity from solid matrix was measured with the extraction method, which does not include matrix bound activity. Valášková and Baldrian (2006) noticed that a significant amount of $P$. ostreatus laccase, but not MnP, was bound to the solid fraction during liquid cultivation. In addition, Heinonsalo et al. (2012) noticed different binding between laccase and $\mathrm{MnP}$ to various agar media.

Table 9. Maximum enzyme activities in the fungal bark inoculum and in the PCDD/F-contaminated soil, where the fungus was growing (incubation time in parenthesis).

\begin{tabular}{|c|c|c|c|c|}
\hline \multirow[t]{2}{*}{ Fungus } & \multicolumn{2}{|c|}{$M n P\left(m U g^{-1}\right)^{a, b}$} & \multicolumn{2}{|c|}{ Laccase $\left(m U g^{-1}\right)^{a, b}$} \\
\hline & activity in bark & activity in soil & activity in bark & activity in soil \\
\hline $\begin{array}{l}\text { Gymnopilus } \\
\text { luteofolius }\end{array}$ & $140 \pm 90(24 d)$ & $290 \pm 80(42 d)$ & $78 \pm 67(21 d)$ & $60 \pm 13(42 d)$ \\
\hline $\begin{array}{l}\text { Phanerochaete } \\
\text { velutina }\end{array}$ & $2310 \pm 1060(21 d)$ & $2460 \pm 1840(63 d)$ & $6 \pm 10(42 d)$ & $55 \pm 32(63 d)$ \\
\hline $\begin{array}{l}\text { Stropharia } \\
\text { rugosoannulata }\end{array}$ & $910 \pm 820(35 d)$ & $1350 \pm 990(70 \mathrm{~d})$ & $18 \pm 31(24 d)$ & $52 \pm 26(14 d)$ \\
\hline $\begin{array}{l}\text { Stropharia } \\
\text { rugosoannulata, } \\
\text { pilot-scale exp. }\end{array}$ & $\begin{array}{c}1670 \pm 1050 \\
(42 \mathrm{~d})^{\mathrm{c}}\end{array}$ & & $16 \pm 28(42 d)^{c}$ & \\
\hline
\end{tabular}

SOM is partly composed of lignocellulose and therefore also other enzymes than LMEs are needed for its degradation. WRF and LDF utilize various extracellular hydrolytic enzymes for the degradation of cellulose and hemicellulose from wood or plant litter (Baldrian and Valášková, 2008). In the pilot-scale experiment, in addition to MnP and laccase, also endo-1,4$\beta$-glucanase $\left(69 \pm 36 \mathrm{mU} \mathrm{g}^{-1}\right)$, endo-1,4- $\beta$-xylanase $\left(39 \pm 18 \mathrm{mU} \mathrm{g}^{-1}\right)$ and endo-1,4- $\beta$-mannanase 
(27 $\pm 14 \mathrm{mU} \mathrm{g}^{-1}$ ) activities were determined from the fungal bark inoculum after six weeks of cultivation. However, these activities were low compared to the high initial MnP activity (1670 $\left.\pm 1050 \mathrm{mU} \mathrm{g}^{-1}\right)$.

\subsection{Degradation of SOM and production of $\mathrm{CO}_{2}$ (Article II)}

\subsubsection{Laboratory scale experiments}

Fungal growth and degradation of $\mathrm{SOM}$ was estimated with $\mathrm{CO}_{2}$ production during growth in soil. Cumulative $\mathrm{CO}_{2}$ productions with four fungi were determined in two types of organic soils: sawmill and shooting range soils (Table 10). Because the duration of the experiments varied, estimated $\mathrm{CO}_{2}$ production for 3 months ( $90 \mathrm{~d}$ ) was calculated to be able to compare the results. It was possible to extrapolate the $\mathrm{CO}_{2}$ production for 3 months, because the cumulative $\mathrm{CO}_{2}$ production was linear at least until day 90 (Article II: Figure 2).

Table 10. Cumulative $\mathrm{CO}_{2}$ production with four fungi in two types of soils

\begin{tabular}{|c|c|c|c|c|c|c|}
\hline Fungus & Soil & Time (d) & $\mathrm{CO}_{2}(\mathrm{~g})^{\mathrm{a}}$ & $\mathrm{CO}_{2}$ in $90 \mathrm{~d}^{\mathrm{b}}$ & $\% \max \mathrm{CO}_{2}{ }^{\mathrm{c}}$ & Source \\
\hline G. luteofolius & Sawmill A & 84 & $15.2 \pm 1.8$ & 16.3 & 4.0 & \multirow{2}{*}{$\begin{array}{l}\text { Article II } \\
\text { unpublished }\end{array}$} \\
\hline G. luteofolius & $\begin{array}{l}\text { Shooting } \\
\text { range }\end{array}$ & 62 & $7.9 \pm 0.9$ & 11.5 & 4.5 & \\
\hline P. velutina & Sawmill A & 70 & $8.3 \pm 2.4$ & 10.7 & 2.6 & \multirow{2}{*}{$\begin{array}{l}\text { Article II } \\
\text { unpublisheo }\end{array}$} \\
\hline P. velutina & $\begin{array}{l}\text { Shooting } \\
\text { range }\end{array}$ & 47 & $7.5 \pm 0.5$ & 14.4 & 5.6 & \\
\hline S. stellatus & Sawmill B & 70 & $23.8 \pm 2.0$ & 30.6 & 9.8 & Article II \\
\hline S. stellatus & $\begin{array}{l}\text { Shooting } \\
\text { range }\end{array}$ & 53 & $14.3 \pm 0.4$ & 24.3 & 9.4 & Article II \\
\hline S. rugosoannulata & Sawmill A & 90 & $19.3 \pm 1.5$ & 19.3 & 4.8 & \multirow{2}{*}{$\begin{array}{l}\text { Article II } \\
\text { unpublisheo }\end{array}$} \\
\hline S. rugosoannulata & $\begin{array}{l}\text { Shooting } \\
\text { range }\end{array}$ & 59 & $6.6 \pm 3.9$ & 10.0 & 3.9 & \\
\hline
\end{tabular}

\footnotetext{
${ }^{a}$ Average value of two replicates \pm range of variation

${ }^{b}$ Theoretical production in $90 \mathrm{~d}$

${ }^{c}$ Calculated based on the total carbon content (Article II: Table 1)
}

S. stellatus was the most efficient fungi to mineralize SOM in both soils. In 3 months nearly 10 $\%$ of SOM would have been degraded when treated with S. stellatus (Figure 12). The average production in the two soils with the three other fungi did not differ much. Surprisingly, even the lead contamination in the shooting range soil (Table 3) did not decrease the $\mathrm{CO}_{2}$ production. Fungi can tolerate higher concentrations of toxic heavy metals than bacteria, but the tolerance of fungal species differ greatly and even tolerant species suffer in the presence of high concentrations (Baldrian, 2003). Tuomela et al. (2005) showed that high concentration of $\mathrm{Pb}$ inhibited the growth of LDF and the activity of some lignin degrading enzymes, but the 
extent of inhibition varied among different LDF species. S. rugosoannulata was one of those fungi tolerant to heavy metals.

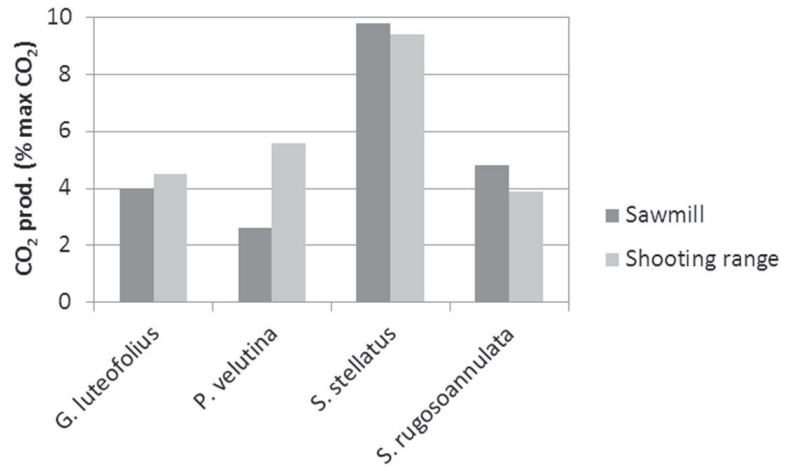

Figure 12. Cumulative $\mathrm{CO}_{2}$ production in $90 \mathrm{~d}$ as percentage from theoretical maximum production (based on the data presented in Table 10).

In spite of the fact, that $S$. stellatus was able to effectively degrade SOM, it was not selected for the pilot-scale experiment. S. stellatus is commonly known as the "cannonball fungi" because this species discharge the spores with explosive force. Discharged spores are sticky and cause persistent dark brown spots on cars, houses, and other surfaces nearby. This feature and the knowledge, that the growth of this fungus is controlled with fungicides (Brantley et al., 2001), might prevent its commercial use. S. rugosoannulata was chosen for a pilot-scale experiment because it performed well in laboratory experiments and because we had more experience with $S$. rugosoannulata from the previous experiments than with the other fungi.

\subsubsection{Pilot-scale experiment}

S. rugosoannulata was selected for the pilot-scale experiment because it represents LDF and thus was expected to be most suitable for growing in the soil. Since this fungus (the wine cap stropharia or burgundy mushroom) is cultivated commercially for food, there is also a lot of experience and research available on its cultivation (Steffen et al., 2007). Extensive fungal growth from inoculum tubes was detected visually already at the beginning of the experiment through the Plexi-glass window (Figure 10B). After the experiment, when the soil was removed from the box, strong and thick mycelia was observed everywhere in the soil. The mycelium was particularly attached to wood pieces in the soil.

The rate of mass loss was constant during the whole experiment (Figure 13: soil + bark inoculum tubes $=308 \mathrm{~kg} \rightarrow 274 \mathrm{~kg}$ ). Dry mass content of the soil did not change during the experiment indicating that evaporation was not the reason for mass loss. Mass loss from bark 
inoculum tubes was $2.2 \mathrm{~kg}$, and $0.8 \mathrm{~kg}$ of mass was lost when samples were taken from the soil. Thus, the corrected mass loss due to degradation of SOM was $31 \mathrm{~kg}$ in 6 months, which represents $9 \mathrm{~kg}$ of dry organic matter and $13 \%$ of the original organic matter content (Table 11). This result supports the result from the laboratory scale experiment where $5 \%$ of SOM in sawmill soil was degraded in 3 months.

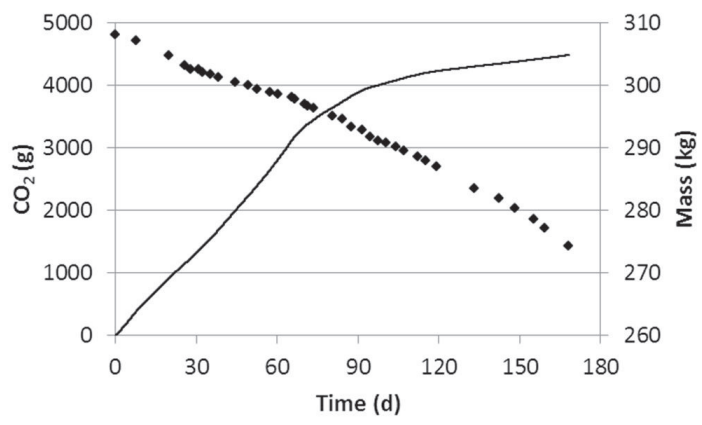

Figure 13. Cumulative $\mathrm{CO}_{2}$ production (line) and total mass of the soil and fungal bark inoculum tubes (•, fresh weight) during the pilot-scale experiment (mass curve also presented in Article II, Figure 6).

Table 11. Degradation of organic matter during pilot-scale experiment with sawmill soil

\begin{tabular}{lrrrrr}
\hline & $\begin{array}{r}\text { Fresh weight } \\
(\mathbf{k g})\end{array}$ & $\begin{array}{r}\text { Dry matter } \\
\mathbf{( \% )}\end{array}$ & $\begin{array}{r}\text { Dry matter } \\
\mathbf{( k g )}\end{array}$ & $\begin{array}{r}\text { Organic matter } \\
\mathbf{( \% )}\end{array}$ & $\begin{array}{r}\text { Organic matter } \\
(\mathbf{k g})\end{array}$ \\
\hline Soil in the beginning & 299 & 29 & 86.7 & $82^{\mathrm{a}}$ & $71.1^{\mathrm{b}}$ \\
Mass loss & 31 & 29 & 9.0 & $100^{\mathrm{c}}$ & $9.0^{\mathrm{d}}$ \\
Soil after 6 months & 268 & 29 & 77.7 & $80^{\mathrm{e}}$ & $62.1^{\mathrm{f}}$ \\
\hline
\end{tabular}

${ }^{a}$ Analyzed from original soil

${ }^{\mathrm{b}}$ Calculated based on the organic matter content (a)

c Theoretical value

${ }^{d}$ Calculated based on the mass loss (fresh weight) and analyzed dry matter content

${ }^{e}$ Calculated based on the mass of organic matter after 6 months ( $f$ ) and the mass of dry matter after 6 months

${ }^{f}$ Calculated by subtracting the mass loss (d) from the mass of the organic matter in the beginning (b)

\subsection{Degradation of PAHs and PCDD/Fs by fungi (Articles III and IV)}

Ten selected fungal strains were screened for their capability to grow in the soil, compete against indigenous microorganisms, and tolerate the contaminants (Table 12). First screening experiment was performed in oil-contaminated soil and fungal strains for further screenings were selected based on these results. None of the fungi showed visible growth in the PAHcontaminated soil (sum of 16 PAHs $6000 \mathrm{mg} \mathrm{kg}^{-1}$ ). Further screening was performed in PAHcontaminated soil, which was diluted with composted green waste (1:1). Even in diluted PAH- 
soil the growth of fungi was inhibited, except the growth of $P$. velutina, when compared with the growth in the control soil (clean soil) or composted green waste (used in the dilution). The strongest growth in PCDD/F-contaminated soil was obtained with $P$. velutina and $S$. rugosoannulata. In addition, G. luteofolius grew into diluted PAH-soil and PCDD/Fcontaminated soil. However, M. galericulata, which grew well in the first screening, did not grow into these contaminated soils. Based on the screening studies, three promising fungal strains for the bioremediation of PAH- and PCDD/F-contaminated soils were found: $G$. luteofolius, $P$. velutina and S. rugosoannulata.

Table 12. Fungal growth in the soil (30 d), screening experiments

\begin{tabular}{|c|c|c|c|c|c|c|c|}
\hline Fungus & $\begin{array}{l}\text { FBCC } \\
\text { number }\end{array}$ & $\begin{array}{l}\text { Oil- } \\
\text { cont. soil }\end{array}$ & $\begin{array}{l}\text { PAH- } \\
\text { cont. soil }\end{array}$ & $\begin{array}{l}\text { Diluted } \\
\text { PAH-soil } \\
\text { (1:1) }\end{array}$ & $\begin{array}{l}\text { Composted } \\
\text { green } \\
\text { waste }\end{array}$ & $\begin{array}{l}\text { PCDD/F- } \\
\text { cont. soil } \\
\text { (Sawmill 1) }\end{array}$ & $\begin{array}{l}\text { Control } \\
\text { soil }\end{array}$ \\
\hline Agrocybe dura & 478 & - & nd & nd & nd & nd & nd \\
\hline $\begin{array}{l}\text { Agrocybe } \\
\text { praecox }\end{array}$ & 587 & - & nd & nd & nd & nd & nd \\
\hline $\begin{array}{l}\text { Gymnopilus } \\
\text { luteofolius }\end{array}$ & 466 & + & $(+)$ & + & +++ & + & ++ \\
\hline Irpex lacteus & 1012 & + & nd & nd & nd & nd & nd \\
\hline $\begin{array}{l}\text { Mycena } \\
\text { galericulata }\end{array}$ & 598 & ++ & - & - & + & $(+)$ & ++ \\
\hline $\begin{array}{l}\text { Phanerochaete } \\
\text { velutina }\end{array}$ & 941 & +++ & - & +++ & +++ & +++ & +++ \\
\hline $\begin{array}{l}\text { Physisporinus } \\
\text { rivulosus }\end{array}$ & 939 & $(+)$ & - & + & $(+)$ & $(+)$ & $(+)$ \\
\hline $\begin{array}{l}\text { Stropharia } \\
\text { aeruginosa }\end{array}$ & 521 & - & nd & nd & nd & nd & nd \\
\hline $\begin{array}{l}\text { Stropharia } \\
\text { rugosoannulata }\end{array}$ & 475 & ++ & nd & nd & +++ & ++ & +++ \\
\hline $\begin{array}{l}\text { Trametes } \\
\text { ochracea }\end{array}$ & 1011 & + & nd & nd & nd & nd & nd \\
\hline \multicolumn{8}{|l|}{ Evaluation: } \\
\hline \multicolumn{8}{|l|}{ - = no growth } \\
\hline \multicolumn{8}{|c|}{$(+)=$ fungal growth only on the bark } \\
\hline \multicolumn{8}{|c|}{$+=$ weak growth in the soil } \\
\hline \multicolumn{8}{|c|}{$++=$ moderate growth in the soil } \\
\hline \multicolumn{8}{|c|}{$+++=$ strong growth in the soil } \\
\hline
\end{tabular}

Further biodegradation experiments with $\mathrm{PAH}$ - and PCDD/F-contaminated soils, were continued with $G$. luteofolius, P. velutina and S. rugosoannulata. PAH-contaminated soil diluted with composted green waste $(1: 1)$ and PCDD/F-contaminated soil (Sawmill 2B) were incubated three months with or without fungal inoculum in two litre glass bottles (Figure 9). During fungal incubation, 95 - $96 \%$ of total PAHs were degraded (Figure 14A), which equals to the whole bioaccessible fraction of the PAH compounds (Article IV, Table 3). Covino et al. (2010) determined also the bioaccessible fraction of total PAHs in their studies, and observed 
that treatment with Pleurotus ostreatus degraded $80 \%$ of total PAHs in creosote contaminated soil, which was approximately the whole bioaccessible fraction (82 \%) (Article IV, Table 5).

Even in the control bottle without the fungal inoculum, $70 \%$ of total PAHs were degraded (Figure 14A). However, the degradation results of individual PAH compounds showed that 4ring or larger PAH molecules were degraded significantly more when the fungal inoculum was used in contrast to indigenous microbes alone (Article IV, Table 3). The highest degradation of HMW PAHs was reached with $P$. velutina inoculum. Although $P$. velutina belongs to WRF, it is known to grow also in soil (Bretherton et al., 2006). This treatment (P. velutina together with indigenous microbes) was able to degrade $96 \%$ of 4-ring PAHs and $39 \%$ of 5- and 6-ring PAHs. In the control bottles $55 \%$ of 4-ring PAHs and only $7 \%$ of 5 - and 6-ring PAHs were degraded. HMW PAHs are not easily degraded by bacteria, because the solubility in water decreases with the increase in molecular mass (Johnsen et al., 2005).

A

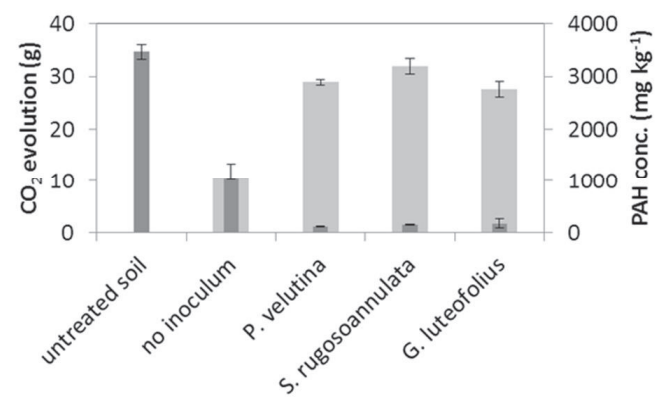

B

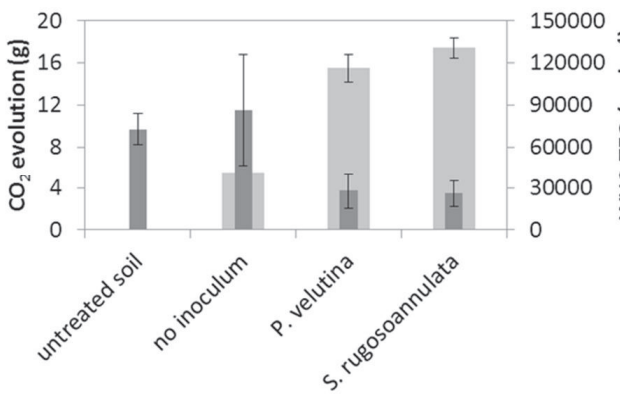

Figure 14. Cumulative $\mathrm{CO}_{2}$ evolution per $100 \mathrm{~g}$ of organic matter (light columns) and A) PAH concentration in soil (dark columns) (Article IV, Figure 2) or B) PCDD/F-concentration in soil (dark columns), before incubation (untreated soil) and after 3 months incubation with or without fungal inoculum (Article III, Figure 1) (average value of three replicates, standard deviations are shown with error bars).

PCDD/F degradation with fungal treatments (P. velutina: $62 \%$, S. rugosoannulata: $64 \%$ ) was significant, and notably there was no degradation in incubated control (Figure 14B). This indicates that indigenous microbes alone were not able to degrade PCDD/Fs. The high variation in analysis results is typical for PCDD/F-contaminated sawmill soils, particularly as the soil was sieved through rather coarse $5 \mathrm{~mm}$ mesh. Sieving through $2 \mathrm{~mm}$ mesh requires drying the soil, which in turn would have killed part of the indigenous microbial community. Since we wanted to work with non-sterile soil and mimic the conditions in field scale, we chose to work with more heterogeneous soil.

One critical factor for efficient biodegradation in non-sterile contaminated soils is strong growth of fungal mycelia in soil. To be able to estimate the microbial activity, $\mathrm{CO}_{2}$ evolution was measured. During microbial growth, bark and $\mathrm{SOM}$ are degraded and $\mathrm{CO}_{2}$ is produced. The 
$\mathrm{CO}_{2}$ production tripled in bottles with fungal inoculum, when compared to the control without inoculum (Figure 14). There were also differences in the $\mathrm{CO}_{2}$ production between the fungi. Treatment with $\mathrm{S}$. rugosoannulata inoculum produced $10 \%$ more $\mathrm{CO}_{2}$ in $\mathrm{PAH}$-contaminated soil and $13 \%$ more $\mathrm{CO}_{2}$ in $\mathrm{PCDD} / \mathrm{F}$-contaminated soil compared to treatment with $P$. velutina. In addition, the mycelium of $S$. rugosoannulata was visually observed to be thicker than that of P. velutina.

Only very few studies describe the use of a fungal inoculum to treat non-sterile PCDD/F-soil from sites with a history of contaminating activities. To my knowledge, only Lamar and White (2007), Kamei et al. (2009), and Valentín et al. (2013) have performed bioaugmentation experiment with contaminated PCDD/F soil. According to Valentín et al. (2013), S. rugosoannulata degraded $14 \%$ 1,2,3,4,6,7,8-HpCDF in 15 weeks. Kamei et al. (2009) showed that Phlebia brevispora was able to degrade $50 \%$ of $1,3,6,8-$ TCDD as the main contaminant in slurry-state conditions in $90 \mathrm{~d}$.

The closest example to our studies was performed by Lamar and White (2007). However, this comparison was not included in Article III because the study was not published in a peerreviewed journal and the description of the materials and methods part was missing. Lamar and White (2007) used several white-rot fungi, including Pleurotus ostreatus and Phlebiopsis gigantea, to treat soil from a former pentachlorophenol dip tank wood-treating operation in New Zealand in a laboratory-scale study. Only the degradation of selected PCDD/Fs was followed (Table 13). In their studies, inoculation with the tested fungi resulted in a significantly greater degradation than without the inoculation.

In our study, treatment with $S$. rugosoannulata resulted in $65 \%$ degradation of the main congener 1,2,3,4,6,7,8-HpCDF in 3 months. Lamar and White (2007) reached even higher degradation of this congener with $P$. ostreatus or $P$. gigantea in 8 weeks (Table 13). The variability in results of these studies may be due to differences in the bioaccessibility of the PCDD/F-congeners in these experimental soils, which was, however, not determined. The persistence of dioxins in the environment is mainly due to their poor bioaccessibility (Field and Sierra-Alvarez, 2008). Dioxins are highly hydrophobic and they tend to become tightly adsorbed in soil particles.

Table 13. Effect of fungal inoculum on degradation of three PCDD/F-congeners in contaminated soil.

\begin{tabular}{lrrr}
\hline PCDD/F-congener & $\begin{array}{r}\text { Degradation with } \\
\text { S. rugosoannulata (\%) } \\
\text { (Article III) }\end{array}$ & $\begin{array}{r}\text { Degradation with } \\
\text { P. ostreatus (\%) }\end{array}$ & $\begin{array}{r}\text { Degradation with } \\
\text { P. gigantea (\%) }\end{array}$ \\
\hline (Lamar and White, 2007) & (Lamar and White, 2007) \\
\hline $1,2,3,4,6,7,8-H p C D F$ & 65.3 & 98.5 & 93.7 \\
$1,2,3,4,6,7,8-H p C D D$ & 45.9 & 97.8 & 91.5 \\
OCDF & 65.3 & nd & nd \\
OCDD & 37.1 & 82.1 & 86.2 \\
\hline nd = not determined & & &
\end{tabular}




\subsection{Degradation of PCDD/Fs by fungal enzymes (Article III)}

The aim of this experiment was to study the PCDD/F degradation capability of MnP in soil and follow changes in the enzyme activity during incubation in vitro. With concentrated crude $\mathrm{MnP}$ extract (activity $4000 \mathrm{U} \mathrm{I}^{-1}$ ) the recovery of $\mathrm{MnP}$ activity from the soil, measured immediately after enzyme addition, was $600 \mathrm{U} \mathrm{I}^{-1}$ in the PCDD/F-contaminated soil and $300 \mathrm{U} \mathrm{I}^{-1}$ in the control soil. MnP activity decreased sharply during the first hour of incubation in both soils, but later the decrease was moderate and substantial activity was still detectable after 10 days of incubation (Article III, Figure 2).

The addition of crude enzyme, with a high MnP activity, did not have any effect to the PCDD/F concentration of the experimental soil (Article III, Figure 2). Nevertheless, in previous experiments non-chlorinated dioxins have be degraded or converted in liquid media by separated enzymes alone, such as peroxygenases (Aranda et al., 2010) or LiP (Hiratsuka et al., 2005). Aranda et al. (2010) showed that APOs from A. aegerita and C. radians were able to oxidize non-chlorinated dibenzofuran to mono-, di- and tri-hydroxylated metabolites. Hiratsuka et al. (2005) showed that purified LiP was able to degrade non-chlorinated dibenzo$p$-dioxin. However, dibenzofuran was not degraded by purified LiP, although both dibenzo- $p$ dioxin and dibenzofuran were metabolized by living mycelia of Phanerochaete chrysosporium. The authors explained this by involvement of intracellular P450, since dibenzofuran was not metabolized by the fungus in the presence of P450 inhibitor. Similar to our experiments, where PCDD/Fs were degraded by the fungus but not by MnP in vitro, Krčmář et al. (1999) showed that PCB was degraded by P. chrysosporium but not by partially purified MnP or LiP. Recently Stella et al. (2013) studied the degradation of chlorobenzoic acid, which is a metabolite of PCB. Lentinus tigrinus was able to degrade chlorobenzoic acid, but either laccase or $\mathrm{MnP}$ produced by this fungus did not have any effect. However, a purified microsomal fraction of L. tigrinus, which contained P450, was able to metabolize chlorobenzoic acid.

P450 might have a central role in the degradation of PCDD/Fs but during fungal growth in soil also other compounds relevant to degradation of contaminants are released, such as unsaturated fatty acids, which are known to take part in MnP catalysed degradation of lignin (Kapich et al., 1999). Unsaturated fatty acids can enhance the activity of MnP in a reaction called lipid peroxidation. First MnP catalyze the formation of peroxyl radicals from unsaturated fatty acids. Then these radicals can further act as oxidants. In our experiment with fungi, fungal inoculum was added to soil growing on pine bark. Pine bark contains unsaturated fatty acids, such as linoleic acid and oleic acid. Valentín et al. (2010) noticed that during cultivation on pine bark, fungi oxidized unsaturated fatty acids. Thus, part of the PCDD/F degradation in our experiment with living fungal mycelia might have been also a result of lipid peroxidation. In the experiments with extracted enzymes, many other beneficial organic compounds produced by fungal mycelia were missing. 


\subsection{Bioremediation of PAH-contaminated soil, field scale experiment (Article IV)}

Two successive field experiments were performed (Table 14). In the first field experiment original, not diluted PAH-soil was used and in the second field experiment PAH-soil was diluted with composted green waste (1:1). Both field experiments were carried out during the summer season (from the beginning of June until the end of October) in Finland. During this time, the temperature inside the soil piles and the experiment hall varied between $6^{\circ} \mathrm{C}$ and $23^{\circ} \mathrm{C}$, and between $2^{\circ} \mathrm{C}$ and $30^{\circ} \mathrm{C}$, respectively. For fungal treatment a daily average temperature of at least $10^{\circ} \mathrm{C}$ is required (Baldrian, 2008). In Southern-Finland a possible treatment time would then be 6 months: from the beginning of May until the end of October.

Table 14. Incubation conditions in the first field experiment (unpublished) and in the second field experiment (Article IV) with PAH-contaminated soil

\begin{tabular}{|c|c|c|c|c|}
\hline \multirow{3}{*}{$\begin{array}{l}\text { Soil } \\
\text { Pile }\end{array}$} & \multirow{2}{*}{\multicolumn{2}{|c|}{$\begin{array}{c}\mathbf{1}^{\text {st }} \text { Field experiment } \\
\text { Original PAH-soil with } \\
\text { some added bark }(4 \% \mathrm{w} / \mathrm{w})\end{array}$}} & \multirow{2}{*}{\multicolumn{2}{|c|}{$\begin{array}{l}\mathbf{2}^{\text {nd }} \text { Field experiment } \\
\text { PAH-soil diluted with } \\
\text { composted green waste (1:1) }\end{array}$}} \\
\hline & & & & \\
\hline & P. ostreatus & No inoculum & P. velutina & No inoculum \\
\hline Dry matter (\%) & $92-94$ & $92-94$ & $68-71$ & $66-69$ \\
\hline Organic matter (\% dm) & $3-4.5$ & $3-4.5$ & $13-16$ & $14-16$ \\
\hline $\mathrm{pH}$ in the beginning & 5.1 & 5.1 & 7.2 & 7.3 \\
\hline $\mathrm{pH}$ at the end & 4.6 & 4.6 & 6.8 & 7.0 \\
\hline Fungal growth & no growth & no growth & strong growth & no growth \\
\hline $\begin{array}{l}\text { Total bacteria, } \\
16 S \text { rDNA copy number } \\
\text { (copies } \mathrm{g}^{-1} \mathrm{dm} \text { ) }\end{array}$ & $10^{9}$ & $10^{9}$ & $10^{10}$ & $10^{10}$ \\
\hline $\begin{array}{l}\text { PAH in the beginning } \\
\left(\mathrm{mg} \mathrm{kg}^{-1}\right)\end{array}$ & 5300 & 5300 & 1400 & 1400 \\
\hline $\begin{array}{l}\text { PAH at the end } \\
\left(\mathrm{mg} \mathrm{kg}^{-1}\right)\end{array}$ & 5200 & 4800 & 90 & 90 \\
\hline
\end{tabular}

The moisture content in the soil was maintained by aeration with moist air. Also covering the piles with tarpaulin helped to prevent drying. Even so, the dry matter content in the first experiment was high during the whole experiment since the original PAH-soil was sandy and contained low amounts of organic matter (Table 14). In the second experiment mixing with composted green waste resulted in higher organic matter content, which also helped to bind moisture in the soil. The $\mathrm{pH}$ decreased in both experiments in all piles (Table 14). In the first experiment this was probably due to the bark amendment and in the second experiment due to microbial growth and formation of organic acids. 
The original soil was too toxic for fungal growth and the high toxicity was also confirmed in the ecotoxicity analysis. The fungus, however, was able to stay alive in the fungal bark inoculum tubes during the first experiment. In the second experiment, with diluted PAH-contaminated soil, fungal mycelium was clearly visible on the surface of the pile after three months of incubation (Figure 15). The visual growth corresponded well with P. velutina ITS region DNA copy number (Figure 16A), which was approximately thousand-fold higher in most of the samples taken from the fungal treatment pile than from the control pile. Composted green waste most likely contained indigenous fungi, although their presence was not directly quantified. However, $P$. velutina DNA copy number in the control pile without the fungal inoculum was elevated, indicating that the primers were not completely specific and that fungi, related to $P$. velutina, were present (Figure 16A).

A

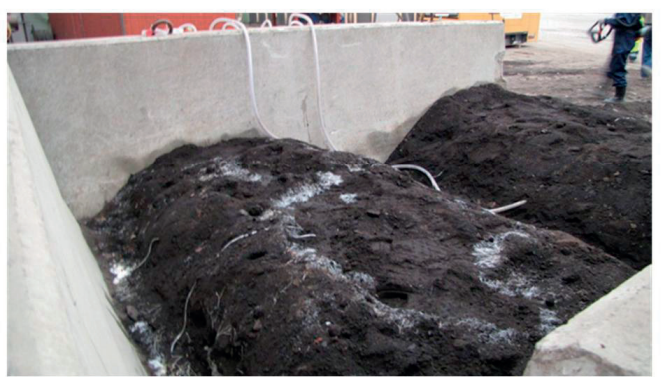

B

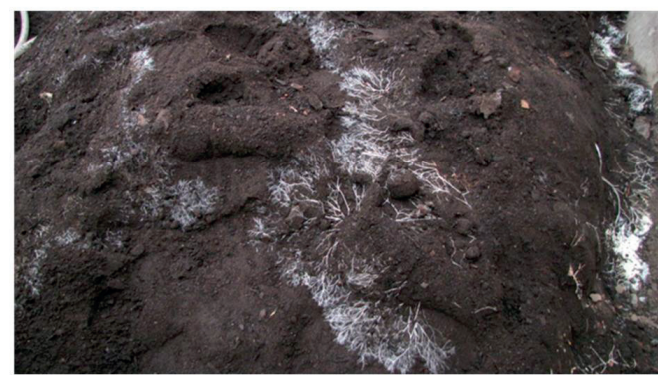

Figure 15. Fungal growth on the surface of the fungal treatment pile after three months of incubation in the second field experiment, A) Fungal treatment pile and control pile, B) Fungal mycelia on the surface of the soil.

The total amount of indigenous bacteria was estimated with bacterial 16S rDNA copy number. In the second field experiment the copy number was ten times higher than in the first experiment (Table 14). The dilution of contaminated soil with composted green waste influenced the microbial activity in three ways: 1) PAH concentration was diluted and the soil was less toxic, 2) soil composition was changed to favour microbial growth (moisture holding capacity, nutrients) and 3) the composted green waste itself acted as a strong microbial inoculant.

In addition, the copy number of dioxygenase genes involved in PAH degradation was measured. In the first field experiment the copy number was $10^{5}$ copies $\mathrm{g}^{-1} \mathrm{dm}$ in both gramnegative and gram-positive bacteria in both piles (inoculum versus no inoculum). Significantly different results were obtained in the second field experiment (Figure 16B). Although the copy number of dioxygenase genes between the two piles (inoculum versus no inoculum) did not vary, the amount of dioxygenase genes in gram-negative and gram-positive bacteria differed greatly. While the copy number in gram-negative bacteria was almost the same during the whole field experiment, the copy number in gram-positive bacteria increased thousand fold 
(from $10^{5}$ to $10^{8}$ copies $\mathrm{g}^{-1} \mathrm{dm}$ ) during the first month of the experiment. Therefore, it could be concluded that in the field experiment with composted green waste, gram-positive bacteria most likely had a significant role in PAH degradation. In an earlier study, where bacteria were isolated from PAH-contaminated soil, most species that could utilize PAHs as sole carbon source were gram-positive actinobacteria (Kästner et al., 1994). Also some gram-positive mycobacteria are known to be able to efficiently degrade particularly 4-ring PAHs (López et al., 2008).

A

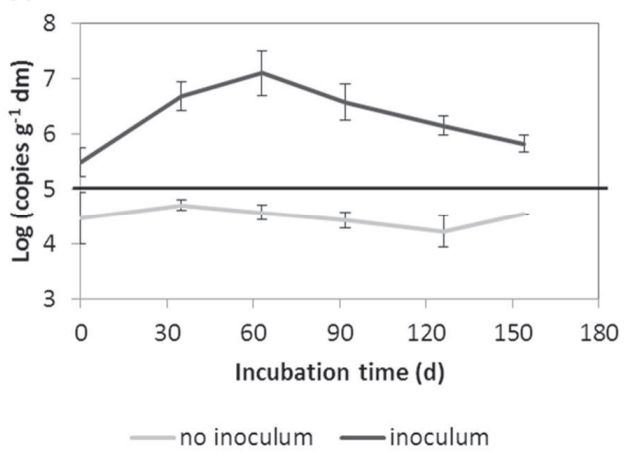

B

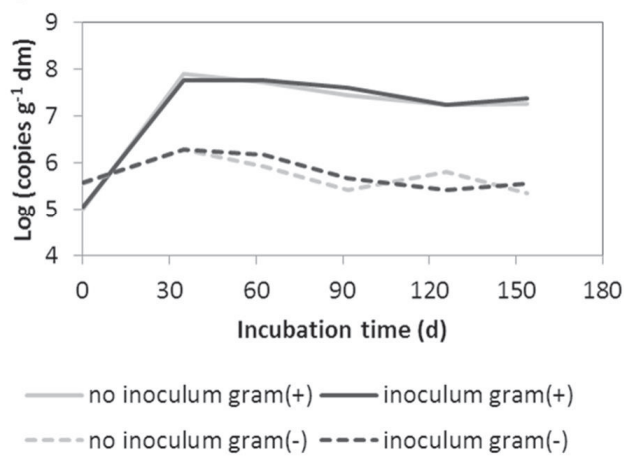

Figure 16. A) The $P$. velutina ITS region DNA copy number in soil during the second field experiment with and without fungal inoculum (detection level is shown as a black line, standard deviations are marked with error bars) (Article IV, Figure 4). B) Amount of dioxygenase genes involved in PAH degradation in gram-negative and gram-positive bacteria in soil during the second field experiment with and without fungal inoculum (standard deviation: $0.02-0.42 \mathrm{log}$, not shown in the figure) (Article IV, Figure 5).

PAH concentration decreased approximately $6 \%$ in the first experiment (Figure 17A) in both piles. However, the degradation was targeted at 3-ring PAHs with approximately $30 \%$ degradation (results not shown). At least part of the 3-ring PAHs has probably also volatilized because the piles were continuously aerated (Semple et al., 2003). For the second experiment, the original PAH-soil was diluted with composted green waste (1:1). Surprisingly the initial PAH concentration of the diluted soil was lower than expected. During the winter period the PAHconcentration had dropped from approximately $5000 \mathrm{mg} \mathrm{kg}^{-1}$ to $2800 \mathrm{mg} \mathrm{kg}^{-1}$ (Table 14). At the end of the first experiment, the aeration was switched off, the fungal bark inoculum tubes were removed from the soil, and the soil was placed in one pile to wait for the further experiment. In spite of that, the indigenous microbes continued to work. The winter period started with improved conditions for microbial growth: the soil was saturated with oxygen due to the mixing of the soil, the toxicity had decreased due to the partly removal of 3-ring PAHs, and most probably the soil did not freeze during winter due to insulating properties of the soil.

In the second field experiment, the PAH concentration dropped from $1400 \mathrm{mg} \mathrm{kg}^{-1}$ to $90 \mathrm{mg} \mathrm{kg}$ ${ }^{1}$ (sum of $16 \mathrm{PAHs}$ ) in both piles already in three months although the field experiment was 
continued for five months (Figure 17B). PAH compounds were degraded in both piles equally: $94 \%$ of total PAHs, $92 \%$ of 3-ring PAHs, $95 \%$ of 4-ring PAHs and $33 \%$ of 5- and 6-ring PAHs. Bark adsorbed $0.2 \%$ of PAHs. The use of fungal inoculum did not increase the degradation of PAHs as in the laboratory experiments (Figure 14A). Possible reason for this was a lower PAH concentration before the treatment in field scale $\left(1400 \mathrm{mg} \mathrm{kg}^{-1}\right)$ compared to that in laboratory scale $\left(3500 \mathrm{mg} \mathrm{kg}^{-1}\right)$. Since the soil was less toxic, the indigenous microbial activity was higher and bioremediation was enhanced.

A

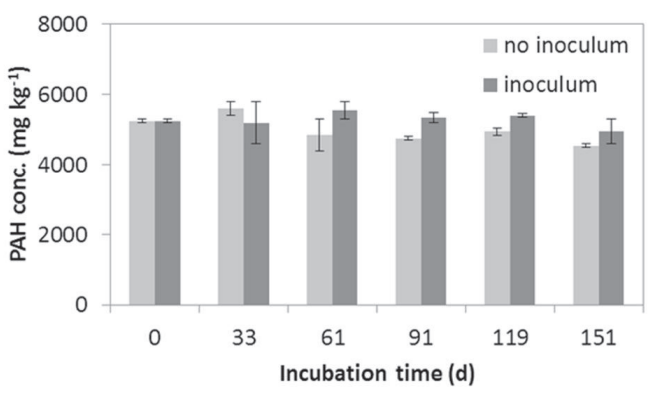

B

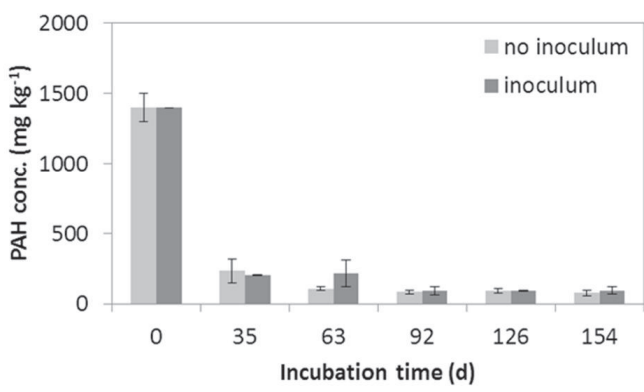

Figure 17. PAH concentrations during the field experiments with and without fungal inoculum (average value of two replicates, the range of variations are shown with error bars), A) First experiment (unpublished), B) Second experiment (Article 4, Figure 3).

Since some of the metabolites, formed during bioremediation of PAH compounds, might be more toxic than the parent compounds (Lundstedt et al., 2007), the soil was tested for ecotoxicity before and after the both field experiments. The toxicity of soil was determined by inhibition of seed germination and survival of earthworms. Germination was strongly inhibited by the original PAH-contaminated soil, particularly with garden cress (Figure 18). Although, the PAH concentration remained almost unchanged, the toxicity, measured by seed germination, decreased during the first experiment. This was probably caused by the degradation of 3-ring PAHs, which are more water soluble and thus cause acute toxicity.

The second field experiment decreased the inhibition for seed germination even more. In both field experiments the treatment with fungal inoculum resulted in slightly higher toxicity compared with no inoculum when measured as inhibition of seed germination. However, the inhibition of seed germination with these two treatments was in the same order of magnitude and in general germination tests are not as sensitive to contaminants as are several soil invertebrates (Dorn et al., 1998; Saterbak et al., 1999). 


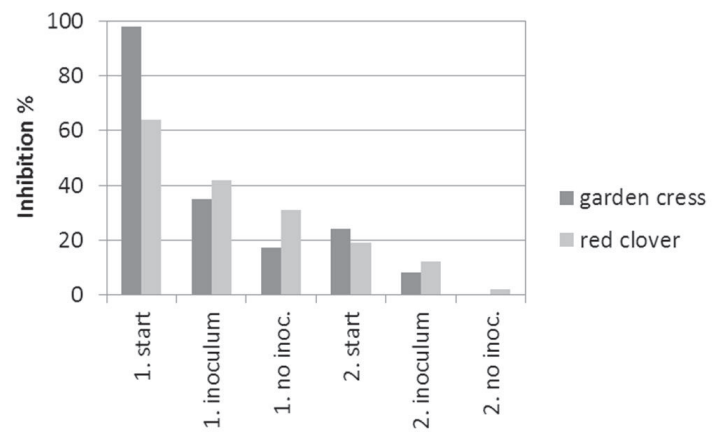

Figure 18. Inhibition of the seed germination, samples taken before (start) and after (inoculum / no inoculum, 5 months) both field experiments (Article 4, Table 4).

The original PAH-contaminated soil was very toxic also to earthworms. All earth worms died after $7 \mathrm{~d}$ exposure to soil which contained only $25 \%$ of the original PAH-contaminated soil (results not shown). In the beginning of the second field experiment, the PAH-soil diluted with composted green waste was still very toxic to earthworms and all of them died within three days from the beginning of the incubation. After the second field experiment, however, acute toxicity had almost disappeared and reproduction in treated soil was even higher than in the control soil (Article 4, Table 4). The toxicity of the soil decreased slightly more when the fungal inoculum was applied than without the inoculum when measured both as the acute death rate and the reproduction of earthworms (Article 4, Table 4). This finding was opposite to the results of the seed germination tests, which underlines the importance to use several ecotoxicity indicators.

The toxicity of PAH-contaminated soil is very difficult to predict only by total PAH concentration. Kreitinger et al. (2007) studied the toxicity of PAHs for earthworms in soil samples collected from manufactured-gas plant sites. Acute toxicity to the earthworm was unrelated to total PAH concentration: earthworms survived in some soils having high concentrations of total PAHs (42 $\left.000 \mathrm{mg} \mathrm{kg}^{-1}\right)$, whereas in other soils having much lower concentrations of total PAHs (1520 $\mathrm{mg} \mathrm{kg}^{-1}$ ) all earthworms died. Instead, toxicity appeared to be related to the rapidly released fraction of $\mathrm{PAHs}$ determined by supercritical $\mathrm{CO}_{2}$ extraction (SFE). This is in agreement with results of Čvančarova et al. (2013) who documented that earthworms are very sensitive towards bioaccessible PAHs. The PAH contaminated soil used in our studies had an average level PAH contamination $\left(5300 \mathrm{mg} \mathrm{kg}^{-1}\right)$, but very high bioaccessible (i.e. rapidly released) fraction determined by SFE (up to $96 \%$, Article IV, Table 3).

To my knowledge, only two other field experiments, where creosote-contaminated soil is treated with fungal inoculum, are reported in the literature (Davis et al., 1993; Lamar et al., 1993). In both of these experiments the use of fungal inoculum enhanced the bioremediation, although Lamar et al. (1993) reported only the degradation of pentachlorophenol $(89 \%$ in 8 weeks) and not the degradation of existing PAHs. Since only limited data from other fungal field experiments was available, also two other field experiments with compost amendment (Cajthaml et al., 2002b; Šašek et al., 2003) were included to the comparison with our results 
(Table 15). Davis et al. (1993) worked with soil contaminated with creosote containing sludge from a wood-preserving facility. After 8 weeks of fungal treatment (Phanerochaete sordida) 91 $\%$ of 3-ring PAHs and $45 \%$ of 4-ring PAHs were degraded. 5- and 6-ring PAHs persisted at their original concentrations. In our field experiment we reached in 13 weeks equal degradation in 3-ring PAHs, but much higher degradation in 4- and 5-/6-ring PAHs (95\% and $33 \%$, respectively). In the two other bioremediation field experiments with compost amendment (Cajthaml et al., 2002b; Šašek et al., 2003), the decrease in total PAH concentration was not as high, but the degradation in 5-/6-ring PAHs was even higher. However, the comparison is difficult since properties of both the soil and the contaminants affect the bioremediation process. All soils in these experiments were from different origins: from a tar producing plant (Cajthaml et al., 2002b), a manufactured gas plant (Šašek et al., 2003) and two different woodpreserving facilities (Davis et al., 1993; Article IV). In addition, the bioaccessibility of PAH compounds in these other soils was not determined. Particularly with studies of Davis et al. (1993), the soil was characterized as clay, which could have led to a strong sorption of PAH compounds to clay minerals.

Table 15. Field scale bioremediation experiments with PAH-contaminated soil

\begin{tabular}{|c|c|c|c|c|}
\hline & $\begin{array}{l}\text { Cajthaml et al. } \\
2002 \mathrm{~b}\end{array}$ & $\begin{array}{l}\text { Šašek et al. } \\
2003\end{array}$ & $\begin{array}{l}\text { Davis et al. } \\
1993\end{array}$ & $\begin{array}{l}\text { Article IV } \\
\text { ( } 2^{\text {nd }} \text { exp.) }\end{array}$ \\
\hline origin of soil & $\begin{array}{l}\text { tar producing } \\
\text { plant }\end{array}$ & $\begin{array}{l}\text { manufactured } \\
\text { gas plant }\end{array}$ & $\begin{array}{l}\text { wood-preserving } \\
\text { facility }\end{array}$ & sawmill \\
\hline fungal inoculum (kg) & no & no & $220 \mathrm{~kg}$ & $70 \mathrm{~kg}$ \\
\hline compost & $\begin{array}{l}\text { mushroom } \\
\text { compost }\end{array}$ & $\begin{array}{l}\text { mushroom } \\
\text { compost }\end{array}$ & no & $\begin{array}{l}\text { composted } \\
\text { green waste }\end{array}$ \\
\hline $\begin{array}{l}\text { soil to compost } \\
\text { dilution ratio }\end{array}$ & $1: 4$ & $1: 4$ & - & $1: 1$ \\
\hline $\begin{array}{l}\text { concentration after } \\
\text { dilution }\left(\mathrm{mg} \mathrm{kg}^{-1}\right)\end{array}$ & 1800 & 600 & not reported & 1400 \\
\hline working scale (kg) & 500 & 1000 & 2200 & 2000 \\
\hline incubation time (d) & 142 & 154 & 56 & 92 \\
\hline \multicolumn{5}{|l|}{ degradation: } \\
\hline total PAHs (\%) & 64 & 69 & not reported & 94 \\
\hline 3-ring PAHs (\%) & 80 & 88 & 91 & 92 \\
\hline 4-ring PAHs (\%) & 65 & 61 & 45 & 95 \\
\hline 5-/6-ring PAHs (\%) & 54 & 57 & 0 & 33 \\
\hline
\end{tabular}




\section{Conclusions and future applications}

According to a recently released report, approximately 1.5 million tons per year of contaminated soil is excavated in Finland (Pyy et al., 2013). The most common handling is disposal to landfill (48 - 58\%), followed by encapsulation (7 - 23\%), stabilization (11- $16 \%$ ), and composting (11 - $14 \%$ ) (Jaakkonen, 2008). Even though $70 \%$ of these soils are contaminated with organic chemicals (Pyy et al., 2013), only one tenth is remediated by composting. There are two possible reasons for this: 1 ) disposal to landfill is fast and obviously too cheap, and thus it does not encourage the use of other treatments, or 2) composting does not offer sufficient remediation. The aim of this thesis was to develop a fungal bioremediation method that could be used for soils heavily contaminated with persistent organic compounds, such as HMW PAHs and PCDD/Fs, which are not degraded in traditional composting.

The basic requirement for an efficient fungal bioremediation is strong growth of fungal mycelia in soil. This can be achieved only if all the following aspects are taken into the consideration:

1) Contaminated soils are very heterogenic, which means that screening studies are required for each individual case to select a suitable fungal strain. It should be able to degrade the organic pollutants in target and tolerate possibly existing other pollutants, e.g. heavy metals.

2) The fungal inoculum should have high viability and it should be free from other contaminating microorganisms. It should be introduced into the soil on a suitable carrier material, which helps the fungus to compete against indigenous microorganisms and thus enables a good starting point for the fungal growth in the soil.

3) Suitable growth conditions need to be maintained in the soil through the whole bioremediation process. Fungi need oxygen for the growth and degradation of organic pollutants. They also need an additional carbon source, since they do not use the pollutants as substrates. And even though fungi can tolerate variation in moisture content, temperature and $\mathrm{pH}$, these parameters must be followed and adjusted for an optimal process.

We were able to show good degradation of HMW PAHs and PCDD/Fs, both in the laboratory and in the field scale. Several promising fungal strains were found and the two most potential species for bioremediation applications were $S$. rugosoannulata, which belongs to LDF and grows naturally in soil, and $P$. velutina, a WRF strain, which is known to grow also in soil. Nonsterile soil from historically contaminated sawmill area was used in all experiments to simulate the conditions in field scale. The highest degradation of HMW PAHs was reached with $P$. velutina inoculum. This treatment ( $P$. velutina together with indigenous microbes) was able to degrade $96 \%$ of 4-ring PAHs and $39 \%$ of 5- and 6-ring PAHs in the laboratory experiments. The bioaccessible fraction of PAHs in soil was determined and it corresponded to the degradation of PAHs. In addition, the degradation of PCDD/Fs with fungal treatments was significant $(P$. velutina: $62 \%$, S. rugosoannulata: $64 \%$ of WHO-TEQ value). 
Fungal treatment of PAH contaminated soil was applied also in the field scale. We were able to sustain strong fungal growth in the contaminated soil, which was confirmed also by a DNA identification method developed for $P$. velutina. After three months treatment, the PAH concentration had dropped from $1400 \mathrm{mg} \mathrm{kg}^{-1}$ to $90 \mathrm{mg} \mathrm{kg}^{-1}$ (sum of $16 \mathrm{PAHs}$ ), which is below the upper base line value (maximum concentration for less sensitive use of soil, e.g. in industrial area.). Even with an efficient bioremediation process some residual contamination is left in the soil, which corresponds to the non-bioaccessible fraction. However, the actual risk of exposure is more important than the total concentration. The evaluation for reuse of the soil, for example in various landscaping, should be based on bioaccessibility analysis and ecotoxicological tests. According to the ecotoxicity tests, a dramatic improvement in the soil quality occurred during the treatment in the field scale. Survival and reproduction of earthworms demonstrated that the soil was suitable as a habitat for these animals after treatment, while the soil before treatment was acutely very toxic. The reduction in toxicity was shown also by seed germination tests.

However, preliminary testing should be required before applying a fungal inoculum. Not only to ensure that the soil is not too toxic for fungal growth, but also to find out whether the addition of fungal inoculum is beneficial. In our case in the field scale, equal degradation of PAHs occurred also in the control pile and thus the addition of fungal inoculum was not necessary. On the contrary, composted green waste, which had been added to PAH-soil as a carbon source for fungal growth, enabled the efficient remediation. Composted green waste enhanced the indigenous microbial activity in three ways: 1) PAH concentration was diluted and the soil was less toxic, 2) soil composition was changed to favour microbial growth (moisture holding capacity, nutrients) and 3 ) the composted green waste itself acted as a strong microbial inoculant. The addition of composted green waste could be even used as a bioremediation method for PAH-soils, when the total concentration of PAHs is not too high and the proportion of HWM-PAHs is not significant. Since the production of fungal inoculum is always an extra cost, fungal treatment is reasonable to apply only for those soils that cannot be bioremediated otherwise. With soils contaminated by chlorinated dioxins, this is always the case.

Fungal treatment was even applied as a pre-treatment for contaminated soil with high organic matter content, and which will be later remediated by combustion. At present, only big rocks are separated from contaminated soil by sieving prior to combustion process. With our method the amount of organic matter in the soil is reduced and the efficacy of the combustion process is improved. In the pilot-scale, $13 \%$ degradation of the original organic matter content was obtained in 6 months.

Another approach for enhanced bioremediation was the use of fungal enzymes instead of fungal culture. The addition of fungal enzymes in a cell free preparation could offer a treatment that is easier to control than by any living organism, and the environmental conditions do not need to be optimal for fungal growth and enzyme production. Fungal enzymes could even be used in situ without the excavation of the contaminated soil. However, at least with $\mathrm{PCDD} / \mathrm{Fs}$, no degradation with a $\mathrm{MnP}$ preparation was observed in the laboratory scale, even though good degradation was obtained with living fungal mycelium. 
Clean environment is crucial to be able to maintain the ecosystem services needed for good quality of life. There is a growing trend that more and more value is put on clean environment. Even in China, where three decades of industrialization have left the country badly polluted, the economic growth at all costs is now restricted to protect the environment. The new policy document, released in November 2013, said "China would put more emphasis on environmental protection when assessing officials, and would also hold local authorities directly responsible for pollution" (Reuters, 2013). When attitudes are changing, also the way to handle contaminated soils and other wastes will change - globally. Instead of dumping contaminated soils to landfill areas, various treatment methods and reuse possibilities are considered. Here bioremediation offers a sustainable treatment method for soils contaminated with organic compounds. 


\section{References}

Alén, R., Structure and chemical composition of biomass feedstocks, In: Alén, R., (Ed.), Biorefining of forest resources, Bookwell Oy, Porvoo (Finland) 2011, pp. 18-54.

Antizar-Ladislao, B., Lopez-Real, J.M., Beck, A.J., Bioremediation of polycyclic aromatic hydrocarbon (PAH)-contaminated waste using composting approaches, Crit. Rev. Environ. Sci. Technol. 34 (2004) 249-289.

Aranda, E., Ullrich, R., Hofrichter, M., Conversion of polycyclic aromatic hydrocarbons, methyl naphtalenes and dibenzofuran by two fungal peroxygenases, Biodegradation 21 (2010) 267281.

Baldrian, P., Wood-inhabiting ligninolytic basidiomycetes in soils: Ecology and constraints for applicability in bioremediation, Fungal Ecology 1 (2008) 4-12.

Baldrian, P., Interactions of heavy metals with white-rot fungi, Enzyme Microb. Technol. 32 (2003) 78-91.

Baldrian, P., Valášková, V., Degradation of cellulose by basidiomycetous fungi, FEMS Microbiol. Rev. 32 (2008) 501-521.

Bezalel, L., Hadar, Y., Cerniglia, C.E., Enzymatic mechanisms involved in phenanthrene degradation by the white rot fungus Pleurotus ostreatus, Appl. Environ. Microbiol. 63 (1997) 2495-2501.

Brantley, E.A., Davis, D.D., Kuhns, L.J., Biological control of the artillery fungus, Sphaerobolus stellatus, with Trichoderma harzianum and Bacillus subtilis, J. Environ. Hort. 19 (2001) 21-23.

Bretherton, S., Tordoff, G.M., Jones, T.H., Boddy, L., Compensatory growth of Phanerochaete velutina mycelial systems grazed by Folsomia candida (Collembola), FEMS Microbiol. Ecol. 58 (2006) 33-40.

Brown, J.A., Glenn, J.K., Gold, M.H., Manganese regulates expression of manganese peroxidase by Phanerochaete chrysosporium, J. Bacteriol. 172 (1990) 3125-3130.

Bunge, M., Adrian, L., Kraus, A., Opel, M., Lorenz, W.G., Andreesen, J.R., Görisch, H., Lechner, U., Reductive dehalogenation of chlorinated dioxins by an anaerobic bacterium, Nature $\mathbf{4 2 1}$ (2003) 357-360.

Cajthaml, T., Möder, M., Kačer, P., Šašek, V., Popp, P., Study of fungal degradation products of polycyclic aromatic hydrocarbons using gas chromatography with ion trap mass spectrometry detection, J. Chromatogr. A 974 (2002a) 213-222.

Cajthaml, T., Bhatt, M., Šašek, V., Matějů, V., Bioremediation of PAH-contaminated soil by composting: A Case study, Folia Microbiologica 47 (2002b) 696-700. 
Cajthaml, T., Erbanová, P., Šašek, V., Möder, M., Breakdown products on metabolic pathway of degradation of benz[a]anthracene by a ligninolytic fungus, Chemosphere 64 (2006) 560-564.

Carabajal, M., Kellner, H., Levin, L., Jehmlich, N., Hofrichter, M., Ullrich, R., The secretome of Trametes versicolor grown on tomato juice medium and purification of the secreted oxidoreductases including a versatile peroxidase, J. Biotechnol. 168 (2013) 15-23.

Carlile, M.J., Watkinson S.C., Gooday, G.W., The Fungi (2nd ed.), Elsevier academic press, London 2004, $588 \mathrm{p}$.

Case, C.L., Basidiomycete Life Cycle, http://www.smccd.edu/accounts/case/fungi/basidio.html, 21.11.2013.

Cebron, A., Norini, M., Beguiristain, T., Leyval, C., Real-time PCR quantification of PAH-ring hydroxylating dioxygenase ( $\mathrm{PAH}-\mathrm{RHD \alpha}$ ) genes from gram positive and gram negative bacteria in soil and sediment samples, J. Microbiol. Meth. 73 (2008) 148-159.

Cerniglia, C.E., Biodegradation of polycyclic aromatic hydrocarbons, Biodegradation 3 (1992) 351-358.

Cerniglia, C.E., Sutherland, J.B., Bioremediation of polycyclic aromatic hydrocarbons by ligninolytic and non-ligninolytic fungi, In: Gadd, G.M., (Ed.), Fungi in Bioremediation, Cambridge University Press, Cambridge 2001, pp. 136-187.

Covino, S., Svobodová, K., Čvančarová, M., D’Annibale, A., Petruccioli, M., Federici, F., Křesinová, Z., Galli, E., Cajthaml, T., Inoculum carrier and contaminant bioavailability affect fungal degradation performances of PAH-contaminated solid matrices from a wood preservation plant, Chemosphere 79 (2010) 855-864.

Čvančarová, M., Křesinová, Z., Cajthaml, T., Influence of the bioaccessible fraction of polycyclic aromatic hydrocarbons on the ecotoxicity of historically contaminated soils, J. Hazard. Mater. 254-255 (2013) 116-124.

Čvančarová, M., Křesinová, Z., Filipová, A., Covino, S., Cajthaml, T., Biodegradation of PCBs by ligninolytic fungi and characterization of the degradation products, Chemosphere 88 (2012) 1317-1323.

Davis, M.W., Glaser, J.A., Evans, J.W., Lamar, R.T., Field evaluation of the lignin-degrading fungus Phanerochaete sordida to treat creosote-contaminated soil, Environ. Sci. Technol. 27 (1993) 2572-2576.

Dorn, P.B., Vipond, T.E., Salanitro, J.P., Wisniewski, H.L., Assessment of the acute toxicity of crude oils in soils using earthworms, Microtox ${ }^{\circledR}$, and plants, Chemosphere 37 (1998) 845-860.

Dupont, Solutions for Garment Laundries, http://primagreen.dupont.com/product solutions/for garment laundries, 1.12.2013.

Durand, A., Bioreactor designs for solid state fermentation, Biochem. Eng. J. 13 (2003) 113-125. Eggert, C., Temp, U., Eriksson, K.E., The ligninolytic system of the white rot fungus Pycnoporus 
cinnabarinus: purification and characterization of the laccase, Appl. Environ. Microbiol. 62 (1996) 1151-1158.

European Community, Regulation No 850/2004 of the European parliament and of the council of 29 April 2004 on persistent organic pollutants and amending Directive 79/117/EEC, http://eur-lex.europa.eu/LexUriServ/LexUriServ.do?uri=OJ:L:2004:158:0007:0049:EN:PDF, 16.9.2013.

Ferguson, B.A., Dreisbach, T.A., Parks, C.G., Filip, G.M., Schmitt, C.L., Coarse-scale population structure of pathogenic Armillaria species in a mixed-conifer forest in the Blue Mountains of northeast Oregon, Can. J. Forest Res. 33 (2003) 612-623.

fibre2fashion, Genencor introduces PrimaGreen EcoFade LT100, http://www.fibre2fashion.com/news/textile-news/denmark/newsdetails.aspx?news id=69189, 16.2.2009.

Field, J.A., Sierra-Alvarez, R., Microbial degradation of chlorinated dioxins. Chemosphere 71 (2008) 1005-1018.

Fujian, X., Hongzhang, C., Zuohu, L., Solid-state production of lignin peroxidase (LiP) and manganese peroxidase ( $\mathrm{MnP}$ ) by Phanerochaete chrysosporium using steam-exploded straw as substrate, Bioresour. Technol. 80 (2001) 149-151.

Furuno, S., Foss, S., Wild, E., Jones, K.J., Semple, K.T., Harms, H., Wick, L.Y., Mycelia promote active transport and spatial dispersion of polycyclic aromatic hydrocarbons, Environ. Sci. Technol. 46 (2012) 5463-5470.

Galhaup, C., Haltrich, D., Enhanced formation of laccase activity by the white-rot fungus Trametes pubescens in the presence of copper, Appl. Microbiol. Biotechnol. 56 (2001) 225-232.

Glenn, J.K., Gold, M.H., Purification and characterization of an extracellular Mn(II)-dependent peroxidase from the lignin degrading basidiomycete Phanerochaete chrysosporium, Arch. Biochem. Biophys. 242 (1985) 329-341.

Glenn, J.K., Morgan, M.A., Mayfield, M.B., Kuwahara, M., Gold, M.H., An extracellular $\mathrm{H}_{2} \mathrm{O}_{2-}$ requiring enzyme preparation involved in lignin biodegradation by the white rot basidiomycete Phanerochaete chrysosporium, Biochem. Biophys. Res. Comm. 114 (1983) 1077-1083.

Gutierréz, A., Del Río, J.C., Ibarra, D., Rencoret, J., Romero, J., Speranza, M., Camarero, S., Martínez, M.J., Martínez, A.T., Enzymatic removal of free and conjugated sterols forming pitch deposits in environmentally sound bleaching of eucalypt paper pulp, Environ. Sci. Technol. $\mathbf{4 0}$ (2006) 3416-3422.

Habe, H., Chung, J.S., Lee, J.H., Kasuga, K., Yoshida, T., Nojiri, H., Omori, T., Degradation of chlorinated dibenzofurans and dibenzo-p-dioxins by two types of bacteria having angular dioxygenases with different features, Appl. Environ. Microbiol. 67 (2001) 3610-3617.

Haderlein, A., Legros, R., Ramsay, B.A., Pyrene mineralization capacity increases with compost maturity, Biodegradation 17 (2006) 293-302. 
Hakala, T.K., Maijala, P., Konn, J., Hatakka, A., Evaluation of novel wood-rotting polypores and corticioid fungi for the decay and biopulping of Norway spruce (Picea abies) wood, Enzyme Microb. Technol. 34 (2004) 255-263.

Hall, I.R., Yun, W., Amicucci, A., Cultivation of edible ectomycorrhizal mushrooms, Trends Biotechnol. 21 (2003) 433-438.

Harms, H., Bioavailability and bioaccessibility as key factors in bioremediation, In: Moo-Young, M., Agathos, S., (Eds.), Comprehensive Biotechnology (2nd ed.), Elsevier, Spain 2011, pp. 83-94.

Harms, H., Schlosser, D., Wick, L.Y., Untapped potential: exploiting fungi in bioremediation of hazardous chemicals, Nature Rev. Microbiol. 9 (2011) 177-192.

Hartikainen, H., Humus - product and source of life, Suo 54 (2003) 137-141.

Hartikainen, H., Maaperä (Soil), In: Heinonen, R., (Ed.), Maa, viljely ja ympäristö (Soil, cultivation and environment), Helsinki 1992, pp. 9-89.

Hatakka, A., Biodegradation of lignin, In: Hofrichter, M., Steinbüchel, A., (Eds.), Lignin, Humic substances and Coal, Vol 1, Wiley-VCH, Weinheim (Germany) 2001, pp 129-180.

Hatakka, A., Lignin-modifying enzymes from selected white-rot fungi: production and role in lignin degradation, FEMS Microbiol. Rev. 13 (1994) 125-135.

Heinonsalo, J., Kabiersch, G., Niemi, M.,Simpanen, S.A., Ilvesniemi, H., Hofrichter, M., Hatakka, A., Steffen, K., Filter centrifugation as a sampling method for miniaturization of extracellular fungal enzyme activity measurements in solid media, Fungal Ecol. 5 (2012) 261-269.

Hibbett, D., et al., A Higher-level phylogenetic classification of the fungi, Mycol. Res. 111 (2007) 509-547.

Hiratsuka, N., Oyadomari, M., Shinohara, H., Tanaka, H., Wariishi, H., Metabolic mechanisms involved in hydroxylation reactions of diphenyl compounds by the lignin-degrading basidiomycete Phanerochaete chrysosporium, Biochem. Eng. J. 23 (2005) 241-246.

Hofrichter, M., Scheibner, K., Schneegass, I., Ziegenhagen, D., Fritsche, W., Mineralization of synthetic humic substances by manganese peroxidase from the white-rot fungus Nematoloma frowardii, Appl. Microbiol. Biotechnol. 49 (1998) 584-588.

Hölker, U., Höfer, M., Lenz, J., Biotechnological advantages of laboratory-scale solid-state fermentation with fungi, Appl. Microbiol. Biotechnol. 64 (2004) 175-186.

Horn, S.J., Vaaje-Kolstad, G., Westereng, B., Eijsink, V.G.H., Novel enzymes for the degradation of cellulose, Biotechnol. Biofuels 5:45 (2012), 12 p.

Husain, Q., Potential applications of the oxidoreductive enzymes in the decolorization and detoxification of textile and other synthetic dyes from polluted water: A review, Crit. Rev. Biotechnol. 26 (2006) 201-221.

Isosaari, P., Tuhkanen, T., Vartiainen, T., Use of olive oil for soil extraction and ultraviolet 
degradation of polychlorinated dibenzo-p-dioxins and dibenzofurans, Environ. Sci. Technol. 35 (2001) 1259-1265.

Jaakkonen, S., Kaivettujen pilaantuneiden maa-ainesten käsittely Suomessa (Treatment of excavated soil in Finland), Suomen ympäristökeskuksen raportteja (Reports of Finnish Environment Institute) 36/2008, Helsinki 2008, 45 p.

Jang, M.-J., Lee, Y.-H., Ju, Y.-C., Kim, S.-M., Koo, H.-M., Effect of color of light emitting diode on development of fruit body in Hypsizygus marmoreus, Mycobiology 41 (2013) 63-66.

Johnsen, A.R., Karlson, U., Diffuse PAH contamination of surface soils: environmental occurence, bioavailability, and microbial degradation, Appl. Microbiol. Biotechnol. 76 (2007) 533-543.

Johnsen, A.R., Wick, L.Y., Harms, H., Principles of microbial PAH-degradation in soil, Environ. Pollut. 133 (2005) 71-84.

Jørgensen, K.S., Puustinen, J., Suortti, A.M., Bioremediation of petroleum hydrocarboncontaminated soil by composting in biopiles, Environ. Pollut. 107 (2000) 245-254.

Kaakkois-Suomen ELY (Centre for Economic Development, Transport and the Environment of Southeast Finland), Kymijoen saastuneet sedimentit (Contaminated sediments in Kymijoki river), http://archive.is/bqaZn, 19.7.2012.

Kabiersch, G., Fungal tools for the degradation of endocrine disrupting compounds, Dissertation, University of Helsinki, Department of Food and Environmental Sciences, Helsinki 2013, 60 p.

Kabiersch, G., Rajasärkkä, J., Ullrich, R., Tuomela, M., Hofrichter, M., Virta, M., Hatakka, A., Steffen, K., Fate of bisphenol A during treatment with the litter-decomposing fungi Stropharia rugosoannulata and Stropharia coronilla, Chemosphere 83 (2011) 226-232.

Kamei, I., Watanabe, M., Harada, K., Miyahara, T., Suzuki, S., Matsufuji, Y., Kondo, R., Influence of soil properties on the biodegradation of 1,3,6,8-tetrachlorodibenzo- $p$-dioxin and fungal treatment of contaminated paddy soil by white rot fungus Phlebia brevispora, Chemosphere 75 (2009) 1294-1300.

Kapich, A., Hofrichter, M., Vares, T., Hatakka, A., Coupling of manganese peroxidase-mediated lipid peroxidation with destruction of nonphenolic lignin model compounds and ${ }^{14} \mathrm{C}$-labeled lignins, Biochem. Bioph. Res. Co. 259 (1999) 212-219.

Kasai, N., Ikushiro, S.-I., Shinkyo, R., Yasuda, K., Hirosue, S., Arisawa, A., Ichinose, H., Wariishi, H., Sakaki, T., Metabolism of mono- and dichloro-dibenzo-p-dioxins by Phanerochaete chrysosporium cytochromes P450, Appl. Microbiol. Biotechnol. 86 (2010) 773-780.

Kästner, M., Breuer-Jammali, M., Mahro, B., Enumeration and characterization of soil microflora from hydrocarbon contaminated soil sites able to mineralize polycyclic aromatic hydrocarbons (PAH), Appl. Microbiol. Biotechnol. 41 (1994) 267-273. 
Kästner, M., Streibich, S., Beyrer, M., Richnow, H.H., Fritsche, W., Formation of bound residues during microbial degradation of $\left[{ }^{14} \mathrm{C}\right]$ anthracene in soil, Appl. Microbiol. Biotechnol. 65 (1999) 1834-1842.

Khan, F.I., Husain, T., Hejazi, R., An overview and analysis of site remediation technologies, J. Environ. Manage. 71 (2004) 95-122.

Kitunen, V.H., Valo, R.J., Salkinoja-Salonen, M., Contamination of soil around wood-preserving facilities by polychlorinated aromatic compounds, Environ. Sci. Technol. 21 (1987) 96-101.

Kohlmeier, S., Smits, T.H.M., Ford, R.M., Keel, C., Harms, H., Wick, L., Taking the fungal highway: mobilization of pollutant-degrading bacteria by fungi, Environ. Sci. Technol. 39 (2005) 46404646.

Korkama, T., Fritze, H., Pakkanen, A., Pennanen, T., Interactions between extraradical ectomycorrhizal mycelia, microbes associated with the mycelia and growth rate of Norway spruce (Picea abies) clones, New Phytol. 173 (2007) 798-807.

Kreitinger, J.P., Quiñones-Rivera, A., Neuhauser, E.E., Alexander, M., Hawthornes, S.B., Supercritical carbon dioxide extractions as a predictor of polycyclic aromatic hydrocarbon bioaccumulation in manufactures-gas plant site soils, Environ. Toxicol. Chem. 26 (2007) 18091817.

Krčmář, P., Kubátová, A., Votruba, J., Erbanová, P., Novotný, Č, Šašek, V, Degradation of polychlorinated biphenyls by extracellular enzymes of Phanerochaete chrysosporium produced in a perforated plate bioreactor, World J. Microbiol. Biotechnol. 15 (1999) 269-276.

Krishnan, A., Stathis, P., Permuth, S., Feldman, D., Bisphenol-A: an estrogenic substance is released from polycarbonate flask during autoclaving, Endocrinology 132 (1993) 2279-2286.

Kudanga, T., Nyanhongo, G.S., Guebitz, G.M., Burton, S., Potential applications of laccasemediated coupling and grafting reactions: A review, Enzyme Microb. Technol. 48 (2011) 195208.

Kües, U., Life History and Developmental Processes in the Basidiomycete Coprinus cinereus, Microbiol. Mol. Biol. Rev. 64 (2000) 316-353.

Laine, M.M., Ahtiainen, J., Wågman, N., Öberg, L.G., Jørgensen, K.S., Fate and toxicity of chlorophenols, polychlorinated dibenzo-p-dioxins, and dibenzofurans during composting of contaminated sawmill soil, Environ. Sci. Technol. 31 (1997) 3244-3250.

Laine, M.M., Jørgensen, K.S., Effective and safe composting of chlorophenol-contaminated soil in pilot scale, Environ. Sci. Technol. 31 (1997) 371-378.

Lamar, R.T., Evans, J.W., Glaser, J.A., Solid-phase treatment of a pentachlorophenolcontaminated soil using lignin-degrading fungi, Environ. Sci. Technol. 27 (1993) 2566-2571. 
Lamar, R.T., White, R.B., Current Progress in the Application of Mycoremediation to Soil Cleanup, In: Hurst, C.J., Crawford, R.L., Garland, J.L., Lipson, D.A., Mills, A.L., Stetzenbach, L.D., (Eds.), Manual of environmental microbiology, ASM Press, Washington (USA) 2007, pp. 10971106.

Leisola, M., Pastinen, O., Axe, D.D., Lignin - Designed randomness, BIO-Complexity (2012) (3) 1-11, doi:10.5048/BIO-C.2012.3.

López, Z., Vila, J., Ortega-Calvo, J.-J., Grifoll, M., Simultaneous biodegradation of creosote polycyclic aromatic hydrocarbons by a pyrene-degrading Mycobacterium, Appl. Microbiol. Biotechnol. 78 (2008) 165-172.

Lundell, T., Mäkelä, M., Puunlahottajat (Wood-degrading fungi), In: Timonen, S., Valkonen, J., (Eds.), Sienten biologia (Biology of fungi), Gaudeamus Oy, Tallinn (Estonian) 2013, pp. 259-279.

Lundstedt, S., White, P.A., Lemieux, C.L., Lynes, K.D., Lambert, I.B., Öberg, L., Haglund, P., Tysklind, M., Sources, fate, and toxic hazards of oxygenated polycyclic aromatic hydrocarbons (PAHs) at PAH-contaminated sites, Ambio 36 (2007) 475-485.

Mannio, J., Leppänen, S., Hirvi, J.P., Pysyvät orgaaniset aineet (Persistent organic pollutants), In: Mähönen, O., (Ed.), AMAP II Lapin ympäristön tila ja ihmisen terveys (Environment and human health in Lapland), Lapin ympäristökeskus (Lapland Environment Institute), Rovaniemi, Suomen ympäristö 581 (2002) 51-61.

Mattila, T., Jääskeläinen, S., Virtanen, V., Moilanen, U., Winquist, E., Bioreactor with an internal conveyor for mixing high viscosity materials, Patent WO2008107518, 12.9.2008.

Mitchell, D.A., Krieger, N., Stuart, D.M., Pandey, A., New developments in solid-state fermentation: II. Rational approaches to the design, operation and scale-up of bioreactors, Process Biochem. 35 (2000) 1211-1225.

Moilanen, U., Kellock, M., Galkin, S., Viikari, L., The laccase-catalyzed modification of lignin for enzymatic hydrolysis, Enzyme Microb. Technol. 49 (2011) 492-498.

Moilanen, U., Osma, J.F., Winquist, E., Leisola, M., Rodríguez Couto, S., Decolorization of simulated textile dye baths by crude laccases from Trametes hirsuta and Cerrena unicolor, Eng. Life Sci. 10 (2010) 242-247.

Moilanen, U., Winquist, E., Mattila, T., Hatakka, A., Eerikäinen, T., Production of manganese peroxidase and laccase in a solid-state bioreactor and modeling of enzyme production kinetics, Bioprocess and biosystems engineering (2014), submitted.

Myllys, L., Stenroos, S., Huhtinen, S., Sienten luokittelu ja evoluutio (Classification and evolution of fungi), In: Timonen, S., Valkonen, J., (Eds.), Sienten biologia (Biology of fungi), Gaudeamus Oy, Tallinn (Estonian) 2013, pp. 11-47.

Nam, I.H., Kim, Y.M., Schmidt, S., Chang, Y.S., Biotransformation of 1,2,3-tri- and 1,2,3,4,7,8hexachlorodibenzo-p-dioxin by Sphingomonas wittichii strain RW1, Appl. Environ. Microbiol. 72 (2006) 112-116. 
Nannipieri, P., Ascher, J., Ceccherini, M.T., Landi, L., Pietramellera, G., Renella, G., Microbial diversity and soil functions, Eur. J. Soil Sci. 54 (2003) 655-670.

Niku-Paavola, M.-L., Karhunen, E., Salola, P., Raunio, V., Ligninolytic enzymes of the white-rot fungus Phlebia radiata, Biochem J 254 (1988) 877-884.

Nojiri, H., Omori, T., Molecular bases of aerobic bacterial degradation of dioxins: involvement of angular dioxygenation, Biosci. Biotechnol. Biochem. 66 (2002) 2001-2016.

Palmieri, G., Giardina, P., Bianco, C., Fontanella, B., Sannia, G., Copper induction of laccase isoenzymes in the ligninolytic fungus Pleurotus ostreatus, Appl. Environ. Microbiol. 66 (2000) 920-924.

Pozdnyakova, N.N., Involvement of the ligninolytic system of white-rot and litter-decomposing fungi in the degradation of polycyclic aromatic hydrocarbons, Biotechnol. Res. Int. (2012), Article ID 243217, $20 \mathrm{p}$.

Pratt, J.E., Niemi, M., Sierota, Z.H., Comparison of three products based on Phlebiopsis gigantea for the control of Heterobasidion annosum in Europe, Biocontrol Sci. Technol. 10 (2000) 467-477.

Pyy, O., Haavisto, T., Niskala, K., Silvola, M., Pilaantuneet maa-alueet Suomessa - Katsaus 2013 (Contaminated soils in Finland - Overview 2013), Suomen ympäristökeskuksen raportteja (Reports of Finnish Environment Institute) 27/2013, Helsinki 2013, 57 p.

Rao, M.A., Scelza, R., Scotti, R., Gianfreda, L., Role of enzymes in the remediation of polluted environments, J. Soil Sci. Plant Nutr. 10 (2010) 333- 353.

Reid, I.D., Paice, M.G., Biological bleaching of Kraft pulps by white-rot fungi and their enzymes, FEMS Microbiol. Rev. 13 (1994) 369-375.

Reuters, To tackle pollution, China to drop pursuit of growth at all costs, http://www.reuters.com/article/2013/11/18/us-china-reform-environmentidUSBRE9AH07M20131118, 18.11.2013.

Rodríguez Couto, S., Sanromán, M.A., Application of solid-state fermentation to ligninolytic enzyme production, Biochem. Eng. J. 22 (2005) 211-219.

Rodríguez Couto, S., Sanromán, M.A., Gübitz, G.M., Influence of redox mediators and metal ions on synthetic acid dye decolorization by crude laccase from Trametes hirsuta, Chemosphere 58 (2005) 417-422.

Ruiz-Dueñas, F.J., Martínez, Á.T., Microbial degradation of lignin: How a bulky recalcitrant polymer is efficiently recycled in nature and how we can take advantage of this, Microbial Biotechnol. 2 (2009) 164-177.

vom Saal, F.S., Hughes, C., An extensive new literature concerning low-dose effects of Bisphenol A shows the need for a new risk assessment, Environ. Health Perspectives 113 (2005) 926-933. 
Sack, U., Hofrichter, M., Fritsche, W., Degradation of polycyclic aromatic hydrocarbons by manganese peroxidase of Nematoloma frowardii, FEMS Microbiol. Lett. 152 (1997) 227-234.

Sanglard, D., Leisola, M.S.A., Fiechter, A., Role of extracellular ligninases in biodegradation of benzo(a)pyrene by Phanerochaete chrysosporium, Enzyme Microb. Tech. 8 (1986) 209-212.

Šašek, V., Bhatt, M., Cajthaml, T., Malachová, K., Lednická, D., Compost-mediated removal of polycyclic aromatic hydrocarbons from contaminated soil, Arch. Environ. Con. Tox. 44 (2003) 336-342.

Saterbak, A., Toy, R.J., Wong, D.C.L., McMain, B.J., Williams, M.P., Dorn, P.B., Brzuzy, L.P., Chai, E.Y., Salanitro, J.P., Ecotoxicological and analytical assessment of hydrocarbon-contaminated soils and application to ecological risk assessment, Environ. Toxicol. Chem. 18 (1999) 15911607.

Semple, K.T., Morriss, A.W.J., Paton, G.I., Bioavailability of hydrophobic organic contaminants in soils: fundamental concepts and techniques for analysis, Eur. J. Soil Sci. 54 (2003) 809-818.

Shamekh, S., Leisola, M., Savonen, E.-L. and Sarjala, T., Establishment of truffleorchads in Finland, Book of Abstract of the Fifth International Workshop of Edible Mycorrhizal Mushrooms, Chuxiong (China) 2007, p. 72.

Singh, H., Mycorrhizal fungi in rhizosphere remediation, In: Singh, H., (Ed.), Mycoremediation Fungal bioremediation, John Wiley \& Sons Inc., New Jersey (USA) 2006, pp. 533-572.

Singh, P., Sulaiman, O., Hashim, R., Rupani, P.F., Peng, L.C., Biopulping of lignocellulosic material using different fungal species: a review, Rev. Environ. Sci. Biotechnol. 9 (2010) 141151.

Snajdr, J., Dobiásová, P., Vetrovský, T., Valásková, V., Alawi, A., Boddy, L., Baldrian, P., Saprotrophic basidiomycete mycelia and their interspecific interactions affect the spatial distribution of extracellular enzymes in soil, FEMS Microbiol. Ecol. 78 (2011) 80-90.

Srogi, K., Levels and congener distributions of PCDDs, PCDFs and dioxin-like PCBs in environmental and human samples: a review, Environ. Chem. Lett. 6 (2008) 1-28.

Steffen, K.T., Schubert, S., Tuomela, M., Hatakka, A., Hofrichter, M., Enhancement of bioconversion of high-molecular mass polycyclic aromatic hydrocarbons in contaminated nonsterile soil by litter-decomposing fungi, Biodegradation 18 (2007) 359-369.

Steffen, K., Tuomela, M., Karikkeenhajottajat (Litter-decomposing fungi), In: Timonen, S., Valkonen, J., (Eds.), Sienten biologia (Biology of fungi), Gaudeamus Oy, Tallinn (Estonian) 2013, pp. 279-289.

Steffen, K.T., Tuomela, M., Fungal soil bioremediation: development for large scale applications, In: Esser, K., Hofrichter, M., (Eds.), Mycota X (2nd ed.), Springer, Berlin, Heidelberg 2010, pp. 451-467.

Stella, T., Covino, S., Křesinová, Z., D’Annibale, A., Petruccioli, M., Čvančarová, M., Cajthaml, T., Chlorobenzoic acid degradation by Lentinus (Panus) tigrinus: In vivo and in vitro mechanistic 
study - evidence for P-450 involvement in the transformation, J. Hazard. Mater. 260 (2013) 975-983.

Subramanian, V., Yadav, J.S., Role of P450 monooxygenases in the degradation of the endocrine-disrupting chemical nonylphenol by the white rot fungus Phanerochaete chrysosporium, Appl. Environ. Microbiol. 75 (2009) 5570-5580.

Sulistyaningdyah, W.T., Ogawa, J., Li, Q.S., Shinkyo, R., Sakaki, T., Inouye, K., Schmid, R.D., Shimizu, S., Metabolism of polychlorinated dibenzo- $p$-dioxin by cytochrome P450BM-3 and its mutant, Biotechnol. Lett. 26 (2004) 1857-1860.

Takada, S., Nakamura, M., Matsueda, T., Kondo, R., Sakai, K., Degradation of polychlorinated dibenzo-p-dioxins and polychlorinated dibenzofurans by the white rot fungus Phanerochaete sordida YK-624, Appl. Environ. Microbiol. 62 (1996) 4323-4328.

Thurston, C.F., The structure and function of fungal laccases, Microbiology 140 (1994) 19-26.

Tien, M., Kirk, T.K., Lignin-degrading enzyme from the hymenomycete Phanerochaete chrysosporium Burds, Science 221 (1983) 661-663.

Torsvik, V., Øvreås, L., Microbial diversity and function in soil: from genes to ecosystems, Curr. Opin. Microbiol. 5 (2002) 240-245.

Tucker, P., Douglas, P., Durrant, A., Hursthouse, A.S., Heavy metal content of newspapers: Longitudinal trends, Environ. Manage. Health 11 (2000) 47-66.

Tuomela, M., Hatakka, A., Oxidative fungal enzymes for bioremediation, In: Moo-Young, M., Agathos, S., (Eds.), Comprehensive Biotechnology (2nd ed.), Elsevier, Spain 2011, pp. 183-196.

Tuomela, M., Steffen, K.T., Kerko, E., Hartikainen, H., Hofrichter, M., Hatakka, A., Influence of $\mathrm{Pb}$ contamination in boreal forest soil on the growth and ligninolytic activity of litterdecomposing fungi. FEMS Microbiol. Ecol. 53 (2005) 179-186.

Ulmer, D., Leisola, M., Puhakka, J., Fiechter, A., Phanerochaete chrysosporium: Growth pattern and lignin degradation, Eur. J. Appl. Microbial. Biotechnol. 18 (1983) 153-157.

Valášková, V., Baldrian, P., Estimation of bound and free fractions of lignocellulose-degrading enzymes of wood-rotting fungi Pleurotus ostratus, Trametes versicolor and Piptoporus betulinus, Res. Microbiol. 157 (2006) 119-124.

Valentín, L., Kluczek-Turpeinen, B., Oivanen, P., Hatakka, A., Steffen, K., Tuomela, M., Evaluation of basiomycetous fungi for pretreatment of contaminated soil, J. Chem. Technol. Biotechnol. 84 (2009) 851-858.

Valentin, L., Kluczek-Turpeinen, B., Willför, S., Hemming, J., Hatakka, A., Steffen, K.T., Tuomela, M., Scots pine (Pinus sylvestris) bark composition and degradation by fungi: potential substrate for bioremediation, Bioresour. Technol. 101 (2010) 2203-2209. 
Valentín, L., Oesch-Kuisma, H., Steffen, K.T., Kähkönen, M., Hatakka, A., Tuomela, M., Mycoremediation of wood and soil from an old sawmill area contaminated for decades, $J$. Hazard. Mater. 260 (2013) 668-675.

Valli, K., Wariishi, H., Gold, M.H., Degradation of 2,7-dichlorodibenzo-para-dioxin by the lignindegrading basidiomycete Phanerochaete chrysosporium, J. Bacteriol. 174 (1992) 2131-2137.

Valtioneuvoston asetus maaperän pilaantuneisuuden ja puhdistustarpeen arvioinnista (Finnish Government Regulation: Evaluation of contamination and need of remediation), VnA 214/2007, Liite: Maaperän haitallisten aineiden pitoisuuksien kynnys- ja ohjearvot (Appendix: Concentration limits of hazardous compounds in soil), http://www.finlex.fi/fi/laki/alkup/2007/20070214, 26.11.2013.

Vartiamäki, H., Maijala, P., Uotila, A., Hantula, J., Characterization of growth and enzyme production of Chondrostereum purpureum isolates and correlation of these characteristics with their capability to prevent sprouting of birch in field, Biol. Control 47 (2008) 46-54.

Viikari, L., Alén, R., Biochemical and chemical conversion of forest biomass, In: Alén, R., (Ed.), Biorefining of forest resources, Bookwell Oy, Porvoo (Finland) 2011, pp. 225-261.

Viniegra-González, G., Favela-Torres, E., Aguilar, C.N., Rómero-Gomez, S.d.J., Díaz-Godínez, G., Augur, C., Advantages of fungal enzyme production in solid state over liquid fermentation systems, Biochem. Eng. J. 13 (2003) 157-167.

Virtanen, V., Nyyssölä, A., Leisola, M., Seiskari, P., An aseptically operatable static solid state bioreactor consisting of two units, Biochem. Eng. J. 39 (2008) 594-597.

de Vrije, T., Antoine, N., Buitelaar, R.M., Bruckner, S., Dissevelt, M., Durand, A., Gerlagh, M., Jones, E.E., Lüth, P., Oostra, J., The fungal biocontrol agent Coniothyrium minitans: production by solid-state fermentation, application and marketing, Appl. Microbiol. Biotechnol. 56 (2001) 58-68.

Wang, C., Sun, H., Li, J., Li, Y., Zhang, Q., Enzyme activities during degradation of polycyclic aromatic hydrocarbons by white rot fungus Phanerochaete chrysosporium in soils, Chemosphere 77 (2009) 733-738.

Wariishi, H., Valli, K., Gold, M.H., Manganese(II) oxidation by manganese peroxidase from the basidiomycete Phanerochaete chrysosporium, J. Biol. Chem. 267 (1992) 23688-23695.

Weber, R., Tysklind, M., Gaus, C., Dioxin - Contemporary and future challenges of historical legacies, Env. Sci. Pollut. Res. 15 (2008) 96-100.

Welch, R.W., Hayward, M.V., Jones, I.H., The Composition of oat husk and its variation due to genetic and other factors, J. Sci. Food Agric. 34 (1983) 417-426.

Wu, J., Xiao, Y-Z., Yu, H-Q, Degradation of lignin in pulp mill wastewaters by white-rot fungi on biofilm, Bioresource Technol. 96 (2005) 1357-1363. 
Ympäristöministeriö (Finnish Ministry of the Environment), Maaperän pilaantuneisuuden ja puhdistustarpeen arviointi (Evaluation of soil contamination and need of remediation), Ympäristöhallinnon ohjeita 2/2007, Helsinki 2007, 210 s.

Yoshida, N., Takahashi, N., Hiraishi, A., Phylogenetic characterization of a polychlorinateddioxin-dechlorinating microbial community by use of microcosm studies, Appl. Environ. Microbiol. 71 (2005) 4325- 4334. 
Ligninolytic fungi, i.e. fungi able to degrade lignin in wood, have the potential to widen the use of bioremediation to soils that are contaminated with the most recalcitrant organic contaminants. Currently this type of contaminants, such as high molecular weight polyaromatic hydrocarbons (HMW PAH) and polychlorinated dibenzo- $p$ dioxins and dibenzofurans (PCDD/F), cannot be degraded efficiently by conventional composting. The only available treatment method is combustion at high temperature. This thesis examines three alternative fungal methods to treat sawmill soils contaminated with either HMW PAHs or PCDD/Fs: 1) treatment with fungal enzymes, 2) treatment with fungal inoculum, and 3) fungal treatment used as a pre-treatment to improve the energy efficacy in combustion.
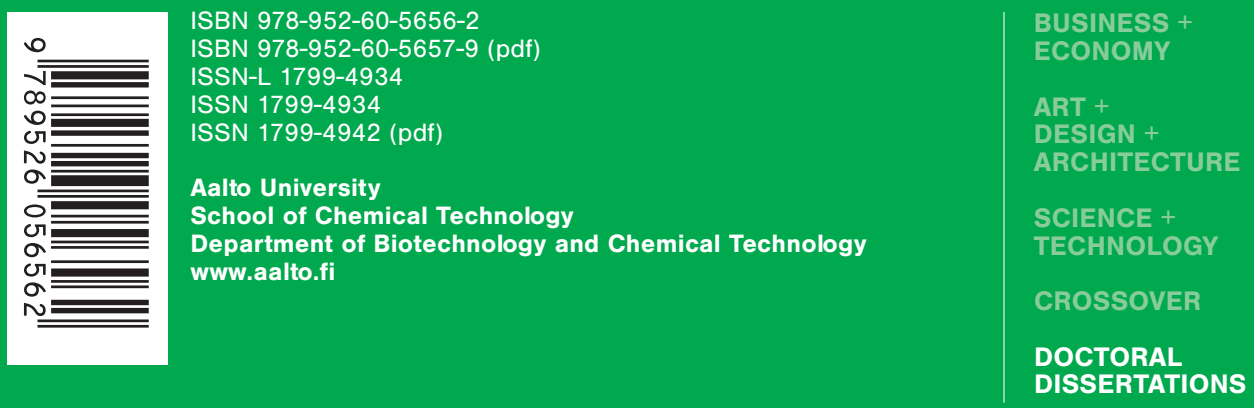